\title{
التصميم والعمارة الداخلية بين التجريب والتنمية المستدامة
}

Design and Interior Architecture between Experiment \& Sustainable Development

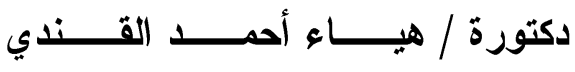

الأستاذ .م نائب رئيس قسم التصميم الداخلي
أ.د. أحمد السيد حسين الحلواني

قسم التصميم الداخلي كلية التربية الأساسية

\section{ملخص البحث}

التطور في العمارة والتصميم الداخلي .. جاء نتيجة حتمية لتعاقب الحضار ات وتطور الأساليب و المدارس ، وكان طبيعياً أن تتطور معها تقنياتها.. وتستقيد في نفس الوقت من تطور العلم والتكنولوجيا.. و الأخذ بالمفهوم الجديد الذي يهدف إلى ترشيد استخدام المصدــم على حو اسه وقدر اته في تحقيق المعادلة المثلى.

وتأتى أهمية البحث في التعريف ببعض المفردات والاصطلاحات الفنية و التصميمية و التي قد يختلف فيها الدارسين ، هذا إلى جانب إلقاء الضوء وطرح بعض قضايا التصميم في هذا العصر.

ويهدف البحث إلى تتمية القدرات الثأملية و التحليلية لاى المصمح من أجل أن تؤثر تصميماته في الوعي الفكري و الجمالي للمشاهد و المتلقي ، و أهمية المصمم في التأكيد

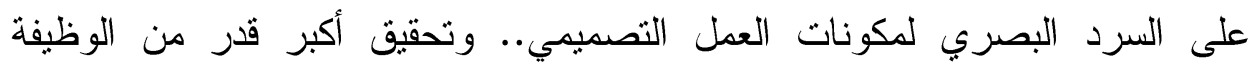
و المتعة البصرية .. هذا بالإضافة إلى فهم واستيعاب المفردات المهمة المرتبطة

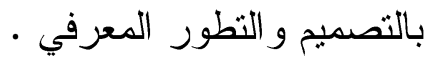


البحث رقم (َ)

\title{
تصميم النصب التذكارية وعلاقتها بتنوع تضاريس الموقع الجغرافية
}

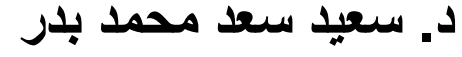 \\ الأستاذ المساعد بقسم النحت - كلية الفنون الجميلة - جامعة الإسكندرية
}


ان الأعمال التذكارية القومية تستمد بعدها القيمي بصورة مباشرة من مدى عضوية تكاملها

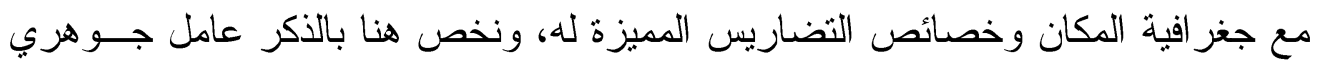

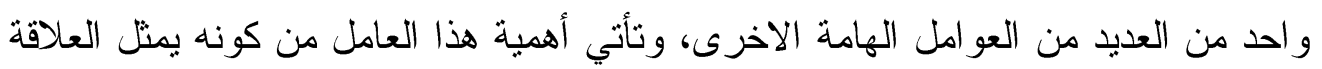

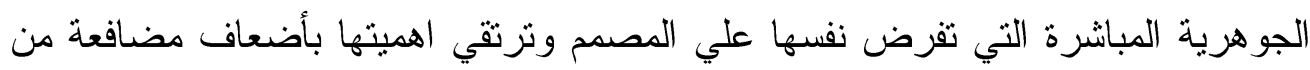

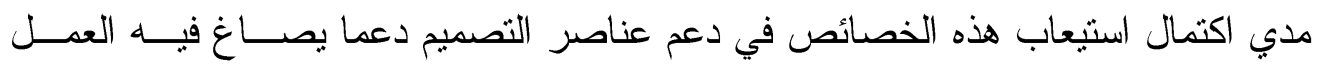

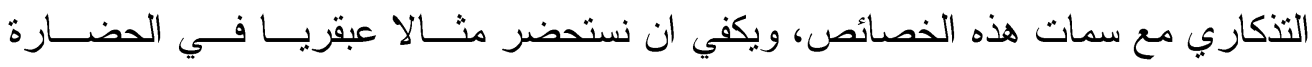

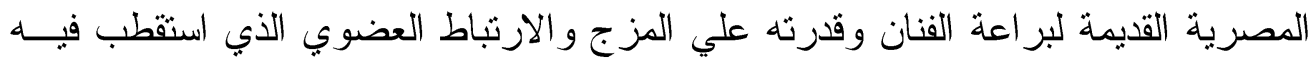
مهابة الجبل و أضفاها علي مهابة معبد الدير البحرى لحتشبسوت (شكل ا ) في بلاغة منفردة وله

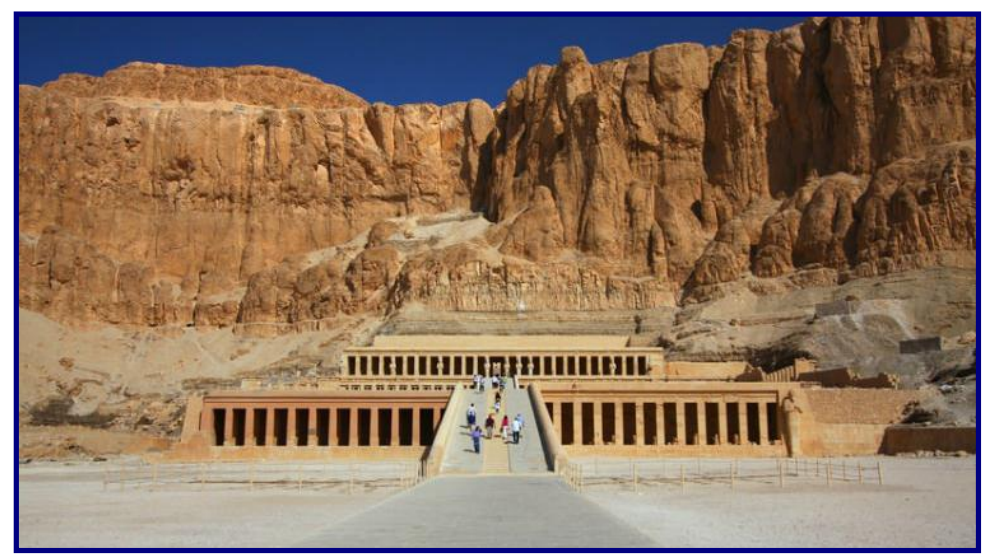

مهيبة

(شكل ( ) لقطة منظورية لمعبد حتشبسوت بالدير البحرى - مدينة الأقصر

ويلاحظ الإرتباط العضوى بين عمارة المعبد وطبيعة الجبل الجغرافية البية

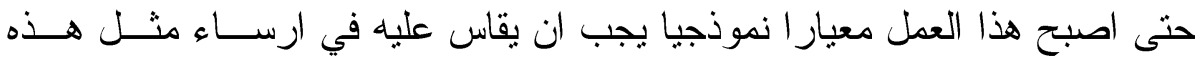

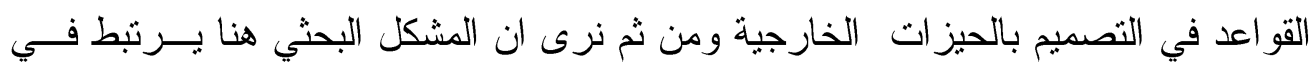

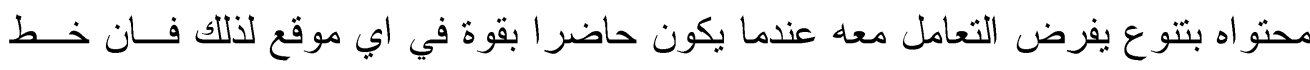

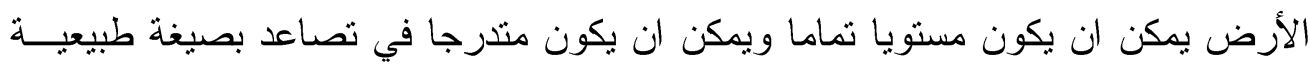

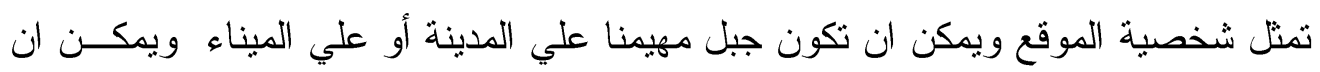

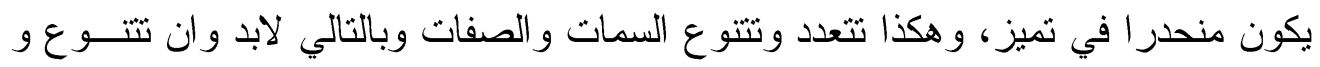

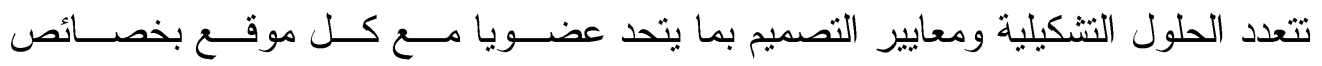

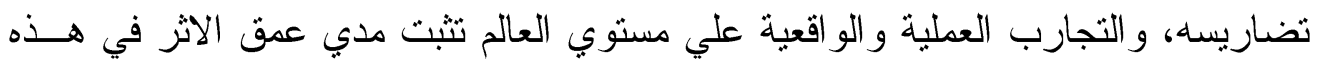

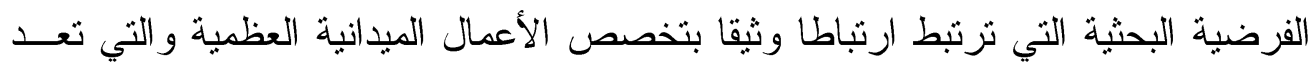


علامات هامة يمكن ان نستخلص منها كل المعايير و القيم التي تثرى الخبــرة الاكاديميــة التخصصية و تسهم في ارساء ضو ابط ومعايير يمكن استلهامها في كل الرؤى التصــميمية لدى الفنانيين المصريين بصفة خاصة ولدى الدارسين في شعبة النحت المبداني بصفة عامة وبناء علي ذلك يمكن ان نستعرض من هذا البحث العناصر الداعية لاثبات هذا الفــرض و معالجة المشكل البحثي من خلاءل مايلي :

\section{طبيعة تنوع التضاريس وعلاقتها بالتصميم}

تتعدد التضاريس الطبيعية لمواقع النصب التذكارية مابين الأسطح الافقية المسـتوية أو التدرج الطبيعي المتصاعد أو الهضاب و الطبيعة الجبلية أو الأسطح المنحدرة وبالتالي فــان كل موقع يتميز بخصائص طبيعية تفرض نفسها علي طبيعة تصميم النصـــب التــكاري و تتوقف عليها المعالجات التشكيلية ومدى فاعلية البعد التعبيري و الرمـزي للنصــب، فــن

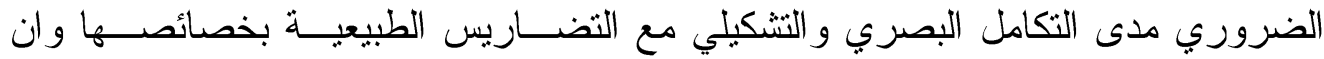
تتضمن معايير تصميم النصب في تخطبط للموقع أو طرز معمارية أو من محددات للرؤية

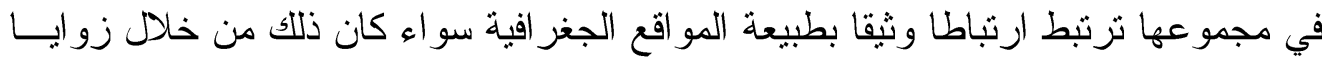

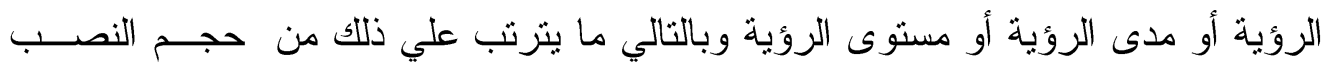

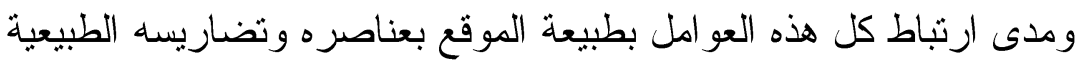
وفيما يلي سنتعرض لدر أسة وتحليل بعض الامثلة للنصب التذكارية التي تؤكد أهمية

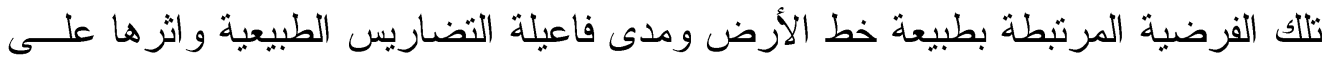
البعد التصميمي و الحلول التشكيلية وما تتضمنه من بعد تعبيري للنصب التذكارية

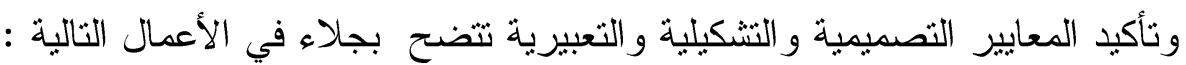

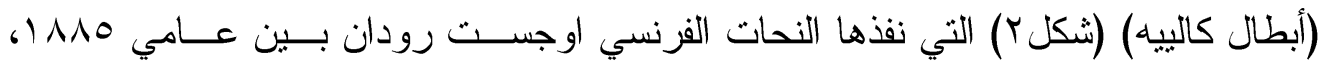

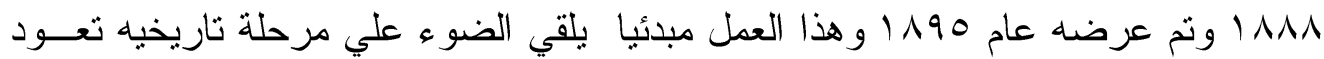
إلى منتصف القرن الرابع عشر عندما قرر الملك الانكليزي ادوارد الثالث احـتلال مدينـــة كاليه Calols الفرنسية علي قنال المانش فاسترجع رودان الحــدث القــديم المتعلــق بهـــا الموضوع فعبر عن أبطال القصة بمجموعة من المو اطنين الذين وهبو انفسهم فداء لمــدينتهم فقدمو ا رهائن إلى معسكر العدو حفاة أذلاء برتدون الثباب الرثة وقد تتاول الفنان هذا العدـلـل

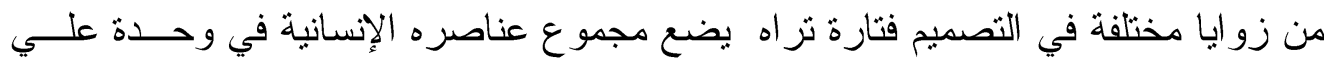
الأرض مباشرة أو حرك مجموع هذه العناصر في صفوف علي مساحة منباعدة الارتفــاع 
بالعناصر على قو اعد منفصلة أو دمج القو اعد بما عليها من عناصر في وحدة تثــكيلية ذات

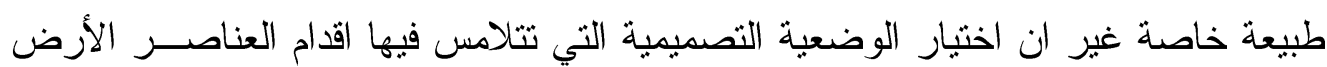

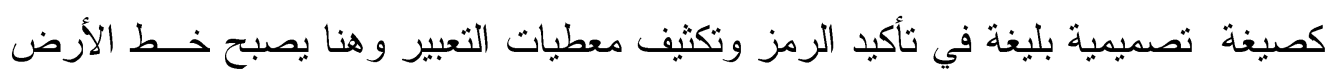

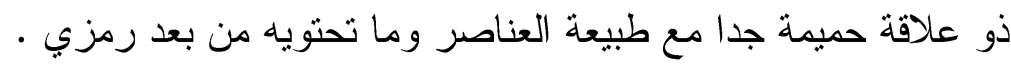

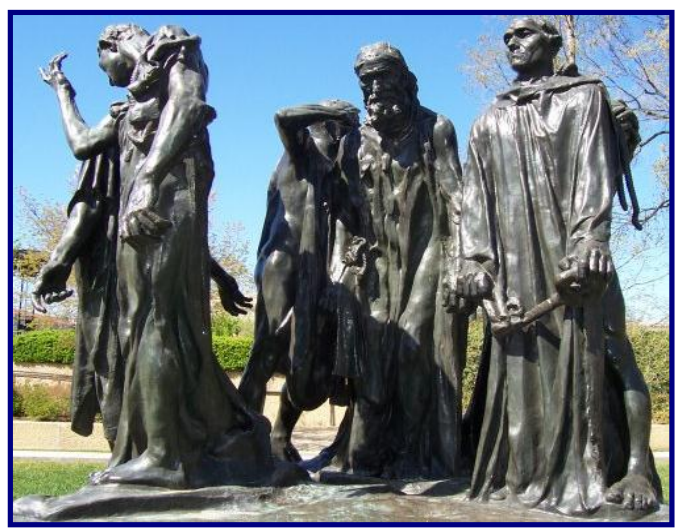

(شكل r ) أبطال كالييه - يتضح فى هذا التكوين الروئية التصميمية المتكاملة

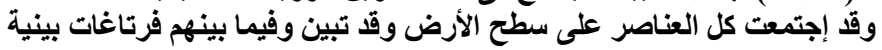

وقد اختلف البعد التعبيرى لكل منهم مع ان مصير ا احدا يجمعه حيث نرئ نرى هيئة الرجل

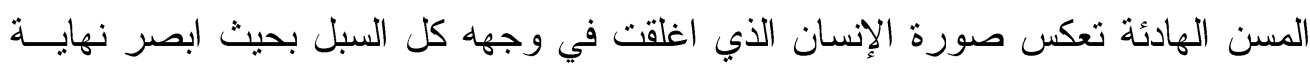

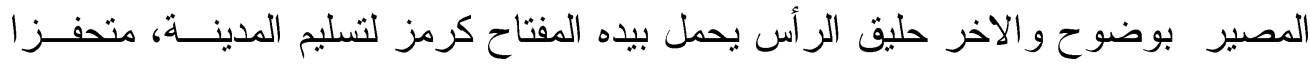

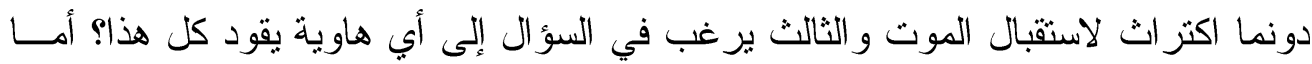

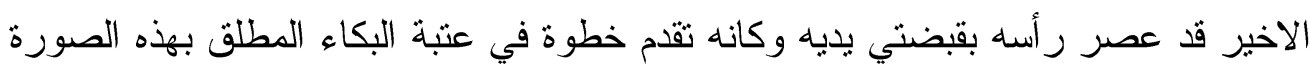

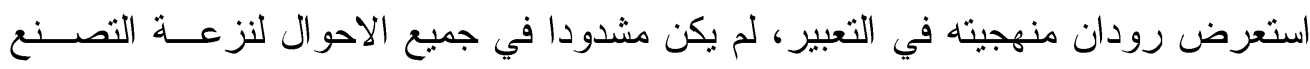

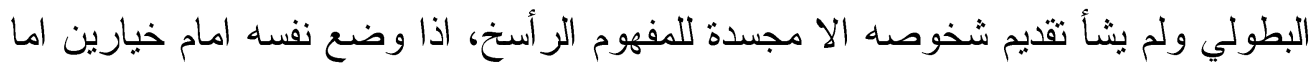

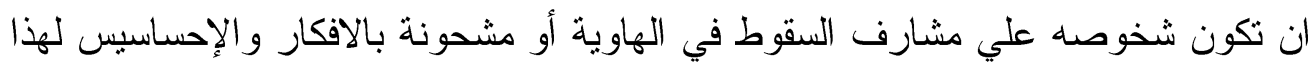

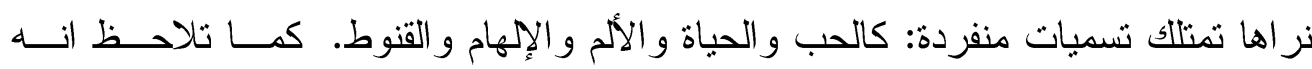

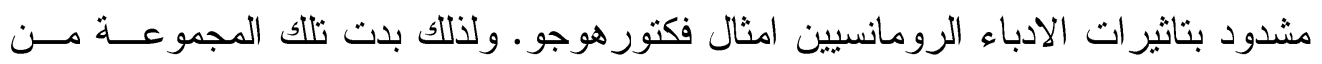

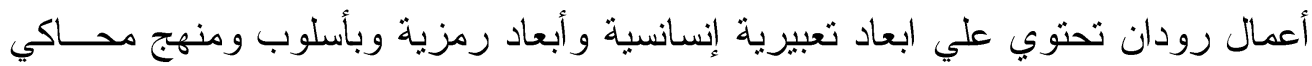

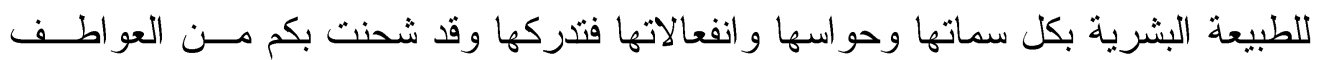

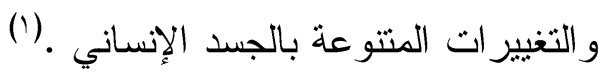

$\left({ }^{1}\right)$ www.ency.com/ar/\%D8 
وبما ان المجموعة باكملها ذات أبعاد تعبيرية و إنسانية تحمل في طياتها معساني مسن

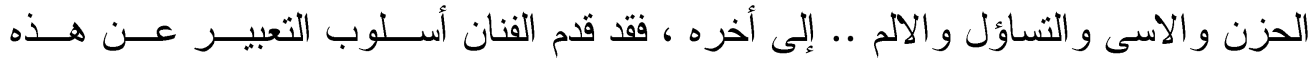
الو اقعة المأسوية في الفر اغ الخارجي وقد بدى كل منهم بحركة إيقاعية مختلفة عن الاخــر

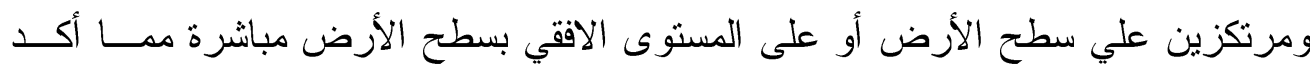

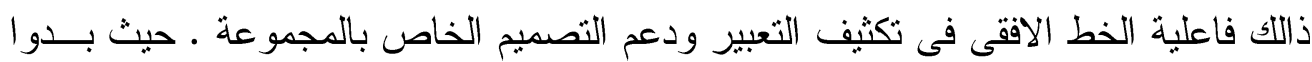
وكأنهم أناس بسطاء يمكن التعامل البصري معهم عن قرب ولم يلجأ إلى عرضـــهم على بـى

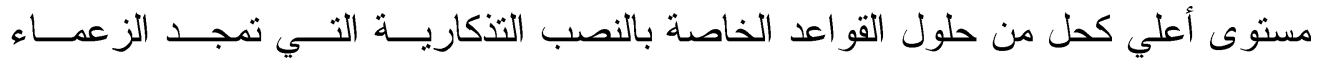

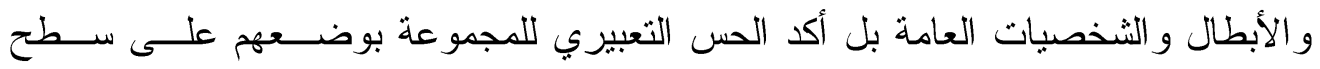

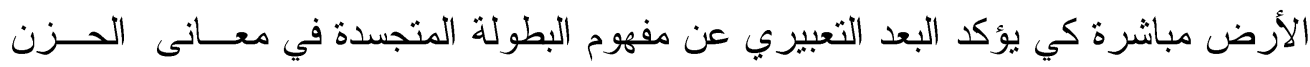
و الاسى.

ولم يؤكد رودان البعد التعبيري والرمزي لهؤلاء الاشخاص عن طريق حركة الجسد

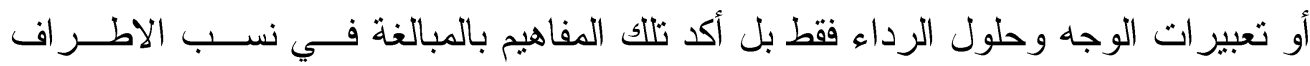

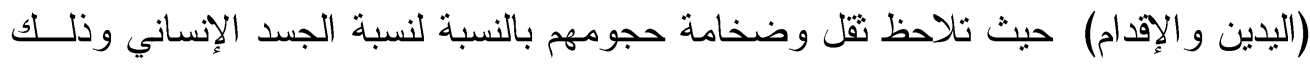

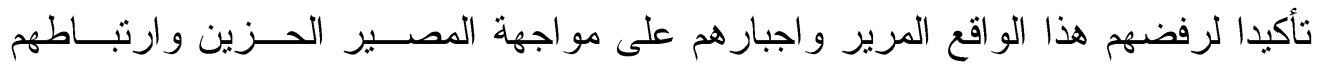

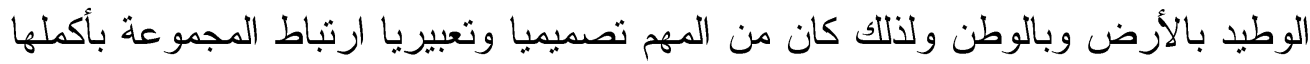

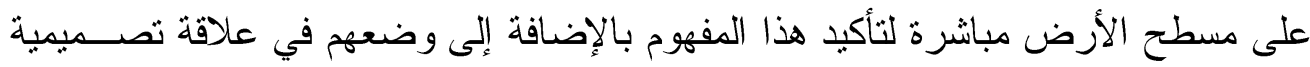

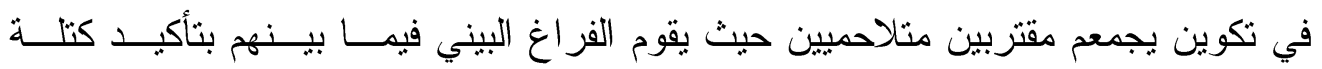
المجموعة فقد وضعهم بحبث تؤول حركة محاور كل فرد إلى الاخر وبالتالي نستمر الرؤية المحيطية .

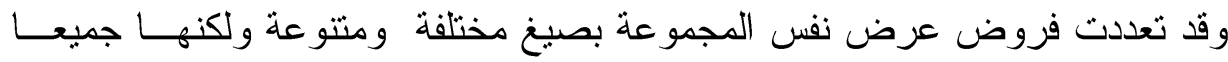

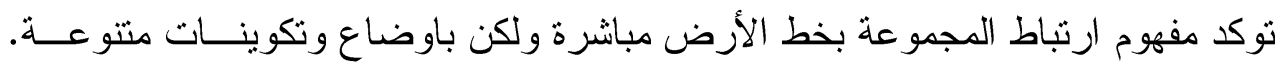

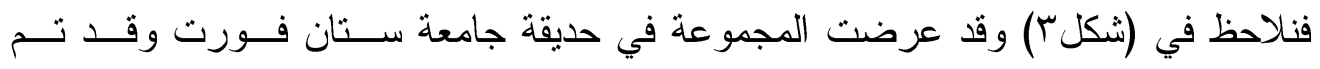
انفصالهم في مساحة فر اغية بحيث بربط بين كل منهم نسبة فر اغ بيني يؤكد ارتباط عناصر

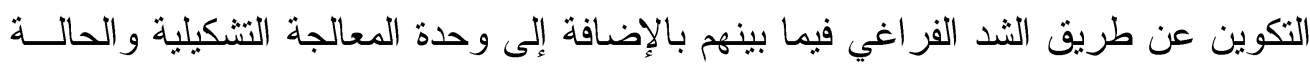

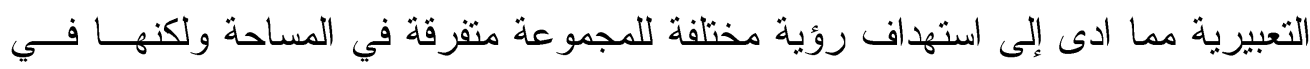
أرتباط بصري وحسي يجمعهم خط الأرض مباشرة وقد نلاحظ ايضا في توزيع المجموعة

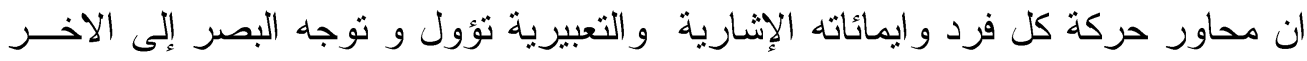




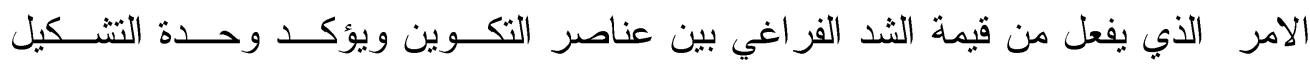

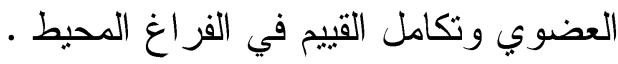

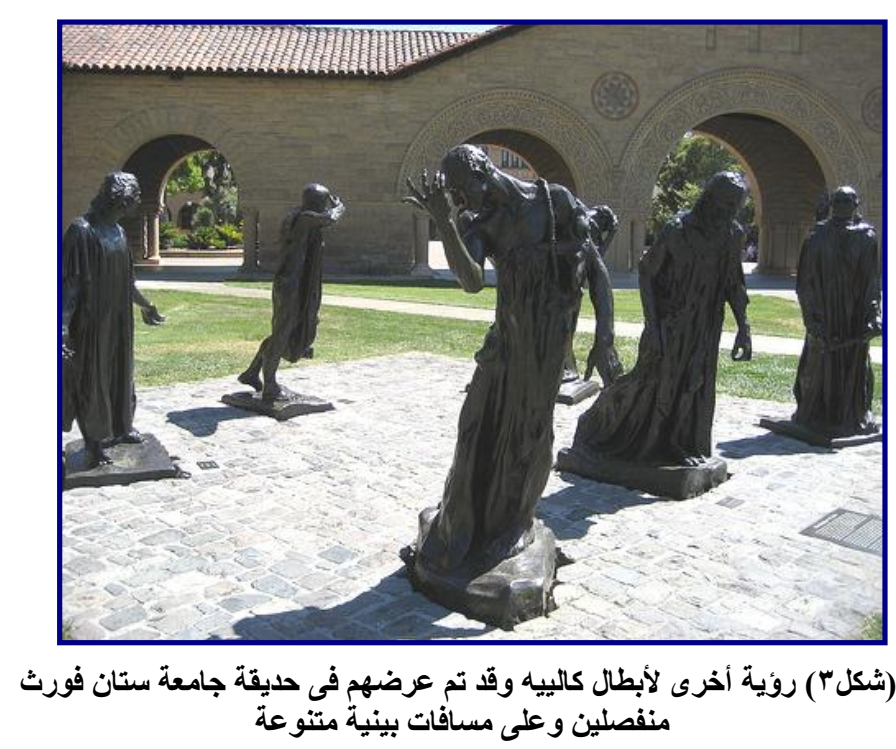

كما يمكن أيضا استحداث فروض لا نهائية من زو ايا الرؤية فبالإضـــافة إلــى امكانيـــة

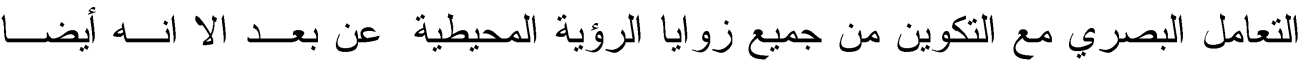

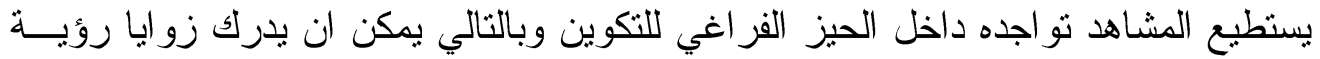

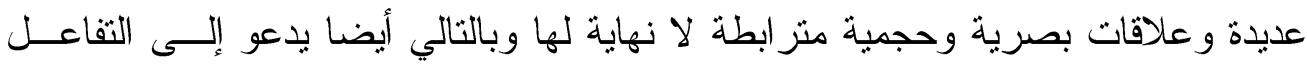

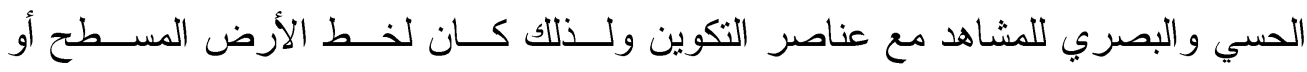

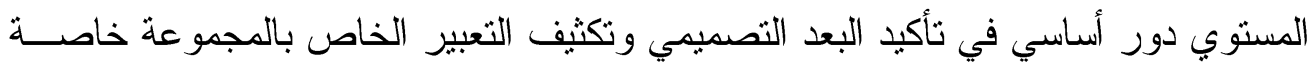
و أن الابعاد اكبر نسبيا بقليل من الحجم الطبيعي وبالتالي يمكننا ادر الك مدى الفاعلية الحسية

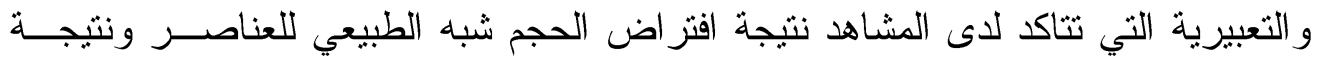

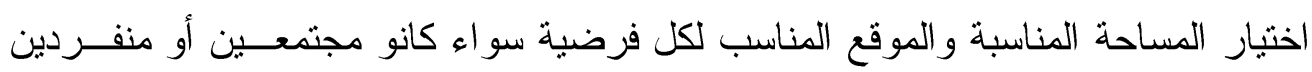
وبطبيعة الحال فان من مشكلات التصميم في الفراغ الخارجي مدى اتساق المجسم النحتـي أو العمل الفني مع عناصر ومحدات الرؤية للموقع سواء كانت عناصر نباتية أو معمارية

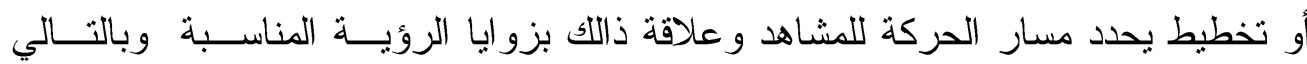

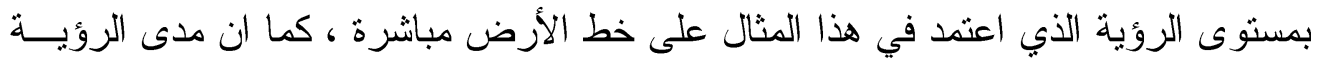

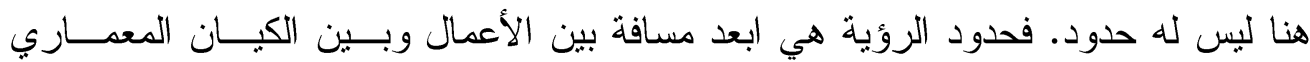


المحيط بحديقة الجامعة اما دون ذلك حتى التواجد داخل كيان التصميم وبـين الفر اغــات

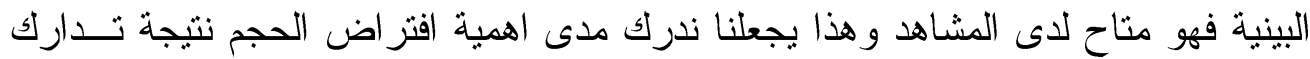

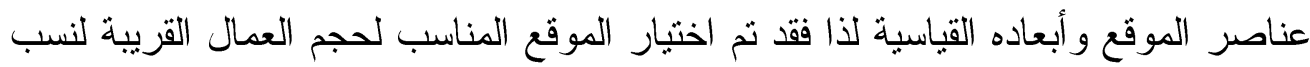
جسم الإنسان العادي تقريبا الا اذا كبر الحجم نسبيا. وبالتالي نستطيع ان ندرك مدى أهمية

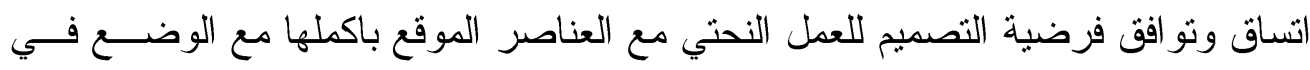

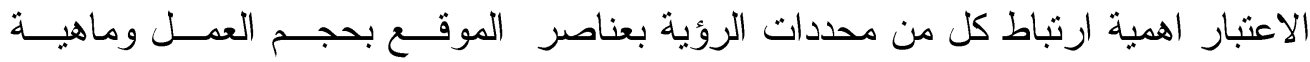

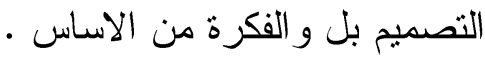
ومثال أخر لمدى أهمية وفاعلية الخط الافقي للأرض لتأكيد البعد التصميمى و التشـــكيلي و التعبيري للنصب التذكاري، وهو نصب الوقت للفنان (تافت لور ادو) (شكلـ) من خامسـة

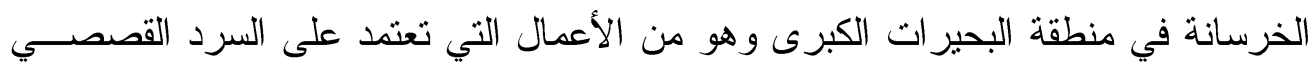
حيث اقيم تخليدا لذكرى الاحداث في التاريخ الامريكي، حيث يحتفل النصب بالمائــة ســنة

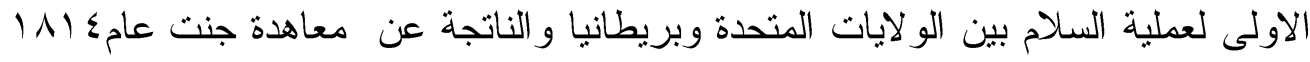
و العمل مستوحي من قصيدة هنرى اوستن دوبسون (مفارقة الوقت) و التي يعبر مخذاها عن حوار بين الوقت و الإنسان فالوقت يمر ويقول يبقي الوقت (الزمن) ويذهب الإنسان وقد بنى ونى وني تصميم الفكرة على مساحة فر اغية يحيطها عناصر نباتية وذو طبيعة أرض مستوية استغلت

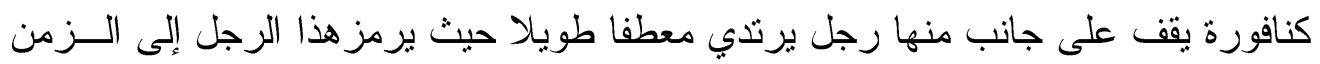

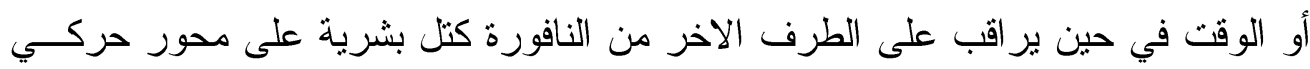
و احد رمزا لمجرى الإنسانية المتدفق والذي يعبر عنها بشخصيات من الاسطورة اليونانية لاعادة تعمير الأرض بعد الطوفان العظيم على هيئة موكب ضخم مكون من مائة شخصية

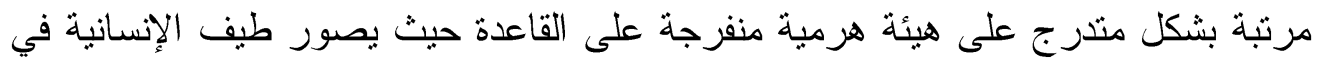

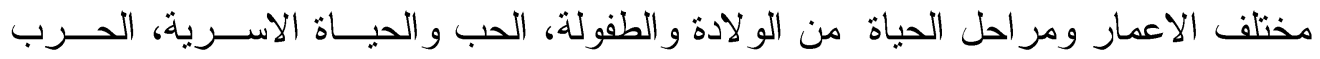

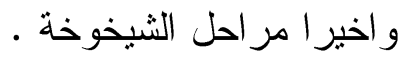




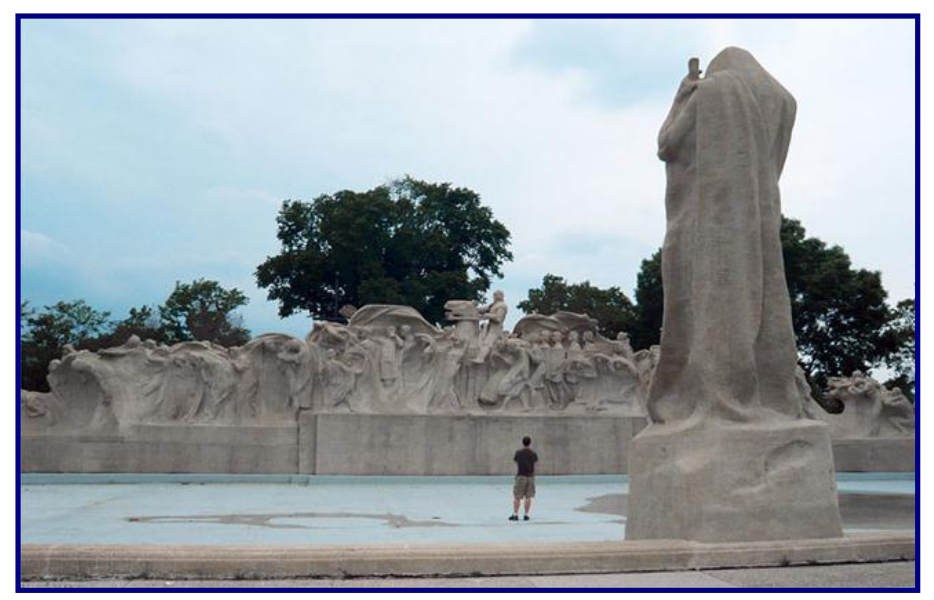

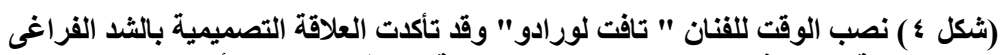

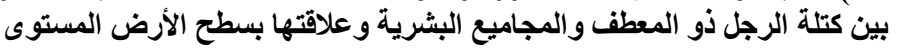

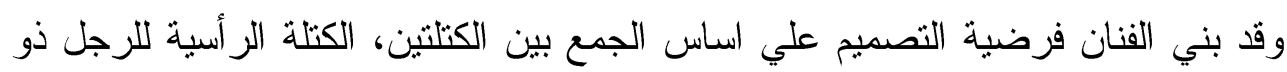

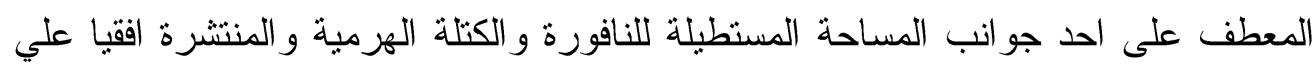
محور واحد على الجانب الاخر واستقرار كل منهم على خط الأرض كبداية بصرية لتفعيل

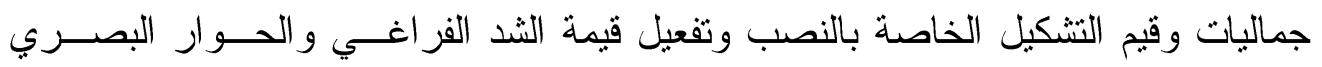

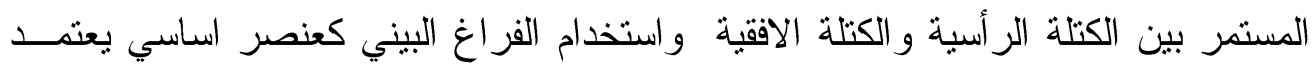

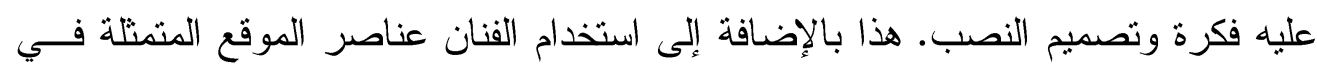

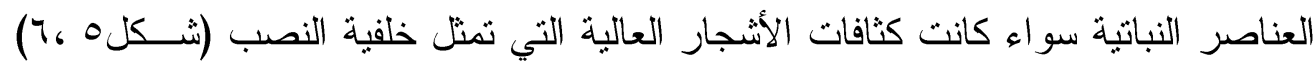

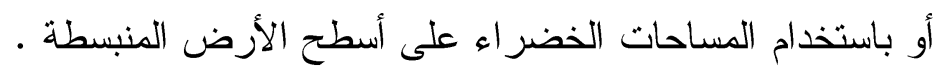

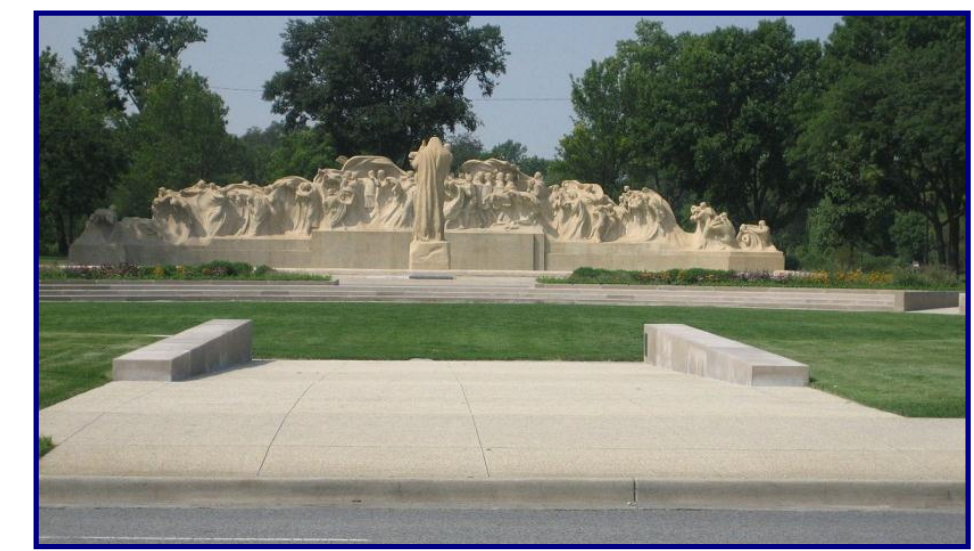

( شكل ه) زاوية روية رئيسية توضح العلاقة بين عناصر النصب وعناصر الموقع النباتية 


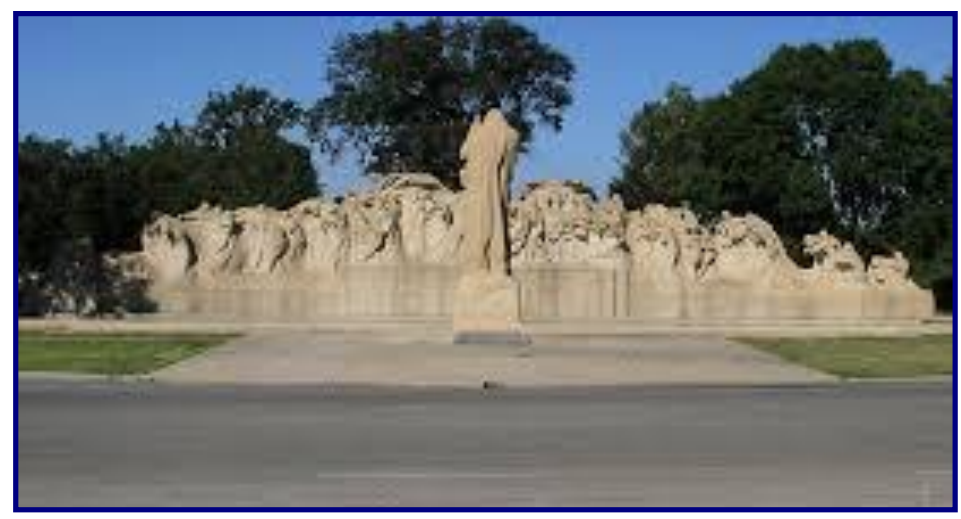

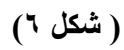

فالكثافات العالية و المثتو عة للأشجار تبدو وكأنها تحيط بالكتلة الافقية وتحتويها نســبيا من الخلف على محور حركة يمثل قوس في حين يقع محور الكتلة الافقية على اطر اف ذلك القوس ومن ناحية اخرى قد خلت تلك الكثافات النباتية على الجانب الاخر حيث تم تصــميم مدخل مثفرغ من ممر حركة لتكون الزاوية الرئيسية للنصب التذكاري مع استخدام عنصر المسطحات النباثية الخضر اء على جانبي النصب بالإضافة إلى العنصر المائي المتمثل فـي النافورة التي تثوسط الكتلتين وثؤكد قيم الثد الفر اغي و العلاقة البصرية بينهما. وقد اختــار الفنان عنصر اللون الخاص بالنصب ذات درجة لونية للبيج الفاتح ( لون الخامة المستخدمة

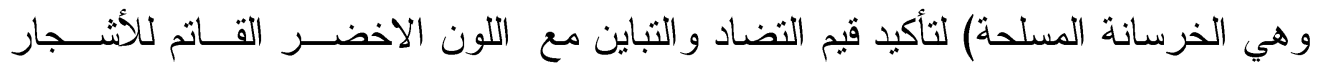
ولون المياه المائل للزرقة و أيضا لون المسطحات الخضر اء على جانبي النصب. وبالتالي قدتم تحقيق الاتساق و التو اقق بين عناصر النصب و الموقع المختار، هذا بالإضافة إلى اهميه تحديد الحجوم المناسبه لمساحه الموقع وبالتالي تحديد زو ايا الرؤيــة ومنســوبها

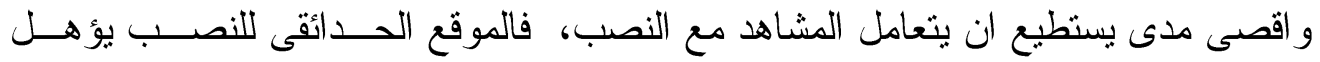
الفنان ان يضع فرضياته المتعلقه بمحددات الرؤية السابق ذكرها بما يتناسب مع المعطيات الخاصه بالموقع وتخطيطه الاولى الأي حدد مسار ات وممرات حركه و اماكن التنز هه وبالنالي فقد افتزض الفنان فرضيه الحجم بناء على تللك المعايير و المفاهيم التي تـؤثر على فعاليه العمل النحتي في الفراغ الخارجي، فنلاحظ ان الزاوية الرئيسية للنصب هـــي الز اوية المتعامدة على محور الكتلة الافقية لما تحتويه هذه الزاوية من أهمية كبـرى فـي ادارك العلاقات التشكيلية و تفاصيل الاشخاص و المعالجة النحتيــة و التعبيريـــة للمجمــوع 
وحيث وان مخروط الرؤية يتعامل مع النصب بكليه و إدر الك بصـرى لكـل تفاصــيل

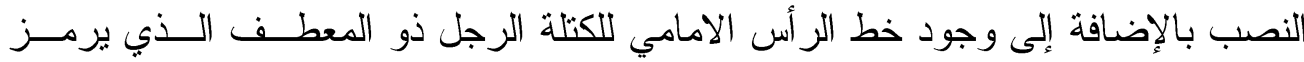

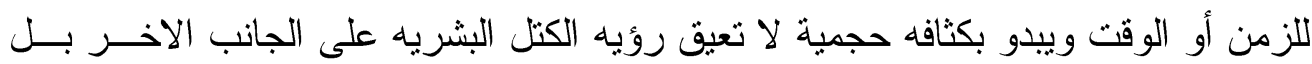

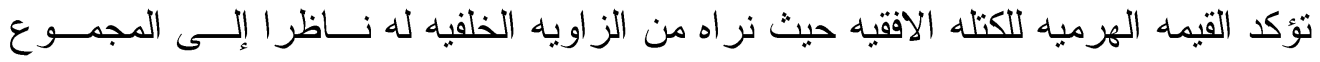

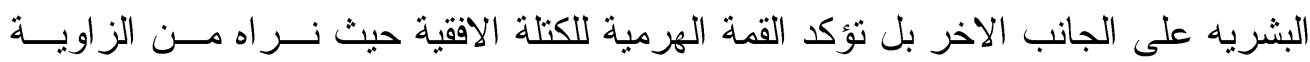

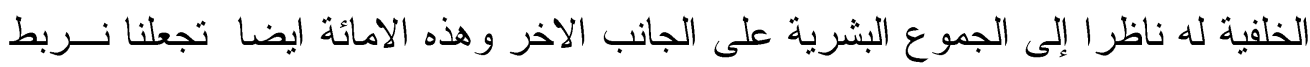
بصريا وتتكيليا وندرك مدى قيمه الثد الفر اغى بين الكتلثنين في المساحه الفر اغيه الخاصة بالموقع

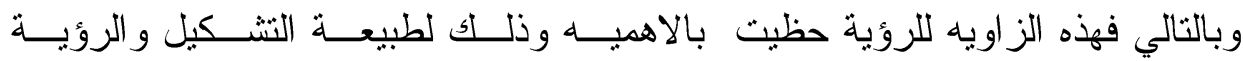

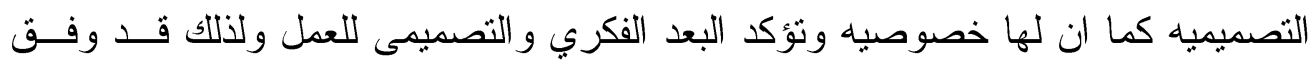

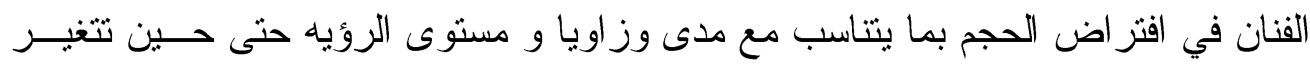

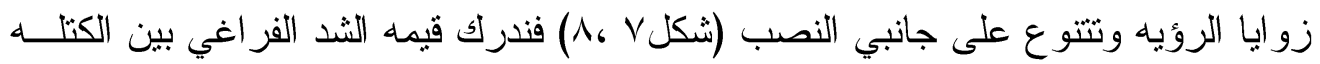

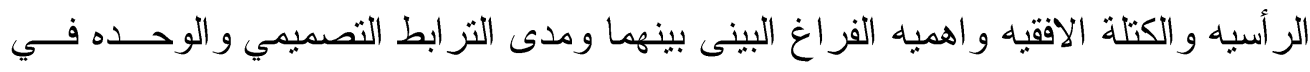

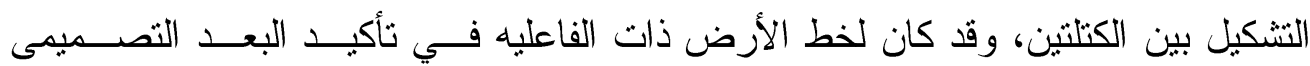

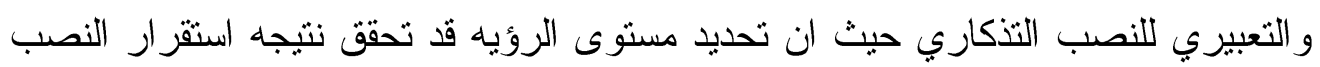
على خط الأرض الافقى المستوى أو المسطح ولذلك قد نلاحظ ان الكتله الافقيه قامت على عدة مستويات هندسيه منصاعده من الجانبين ومن ثم تشكيل الكتل البشريه بإيقاعات ومحاور حركيه ونقلات متعدده و الذبذيــة بصــريه

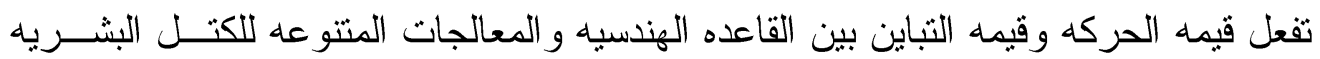
حيث ندرك حركه الخط الخارجي الاعلى للكتل البشريه وقد تميز بإيقاعه الحركي وتتوعـهـ

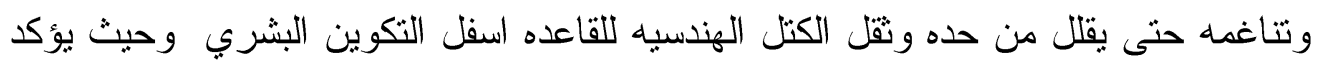

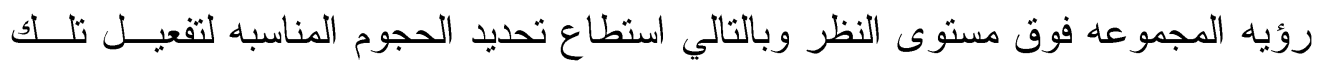
الفرضية و المنطلقة اساسا من فرضيه بناء التصميم على خط الأرض المستوى . 


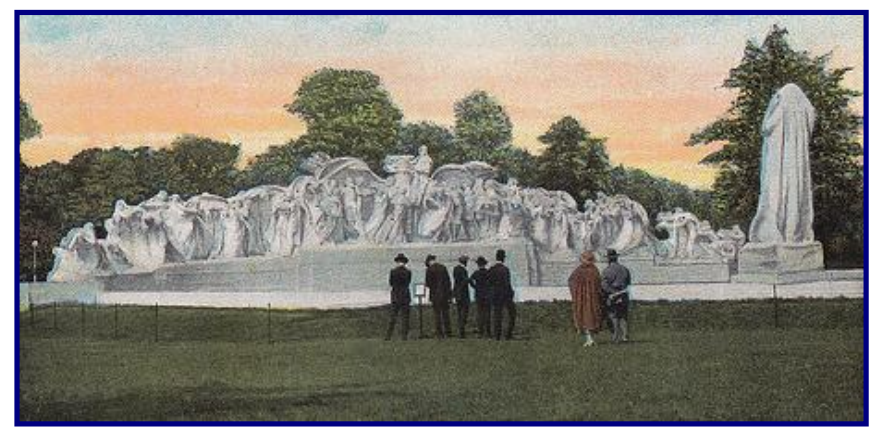

(شكل V) زاوية رؤية جاتبية تؤكد قيم الثد الفراغى بين الكتلتين الرأسية والأفقية وعلاقتهما بخط الأرض المستوى

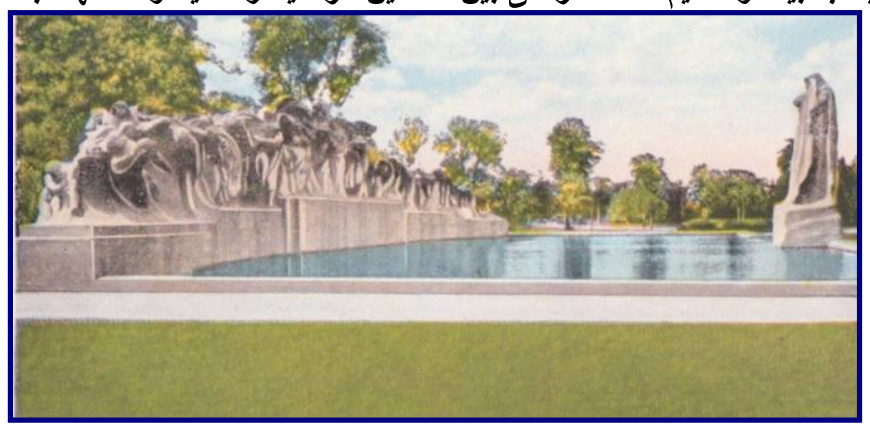

(شنكل)

في حين تم وضع قاعده اسفل الكتلة الرأسيه وقد عولجــت نشـــيليا بــفس أســلوب المعالجات التشكيليه للمعطف وبحيث يمكن تحديد حجم الكتلة الر أسية فتبدأ رؤيثهــا فــوق

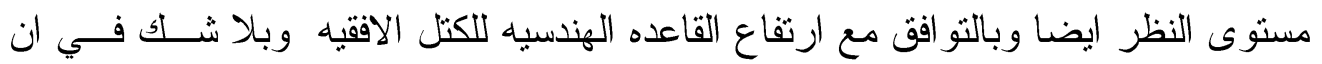
الحجم وبالتالي منسوب الرؤية له اثر و اضتح ايضـا على تحقيق البعــــ التعبيــري لعناصــر النصب ككل حيث بنى على اساس محاكاة الجوانب الإنسانيه للعنصر البشري علـى مــدى

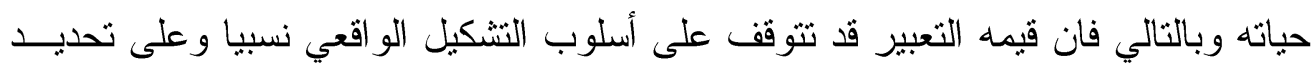
الحجوم المناسبه وبالتالي على منسوب أو مستوى الرؤيه التي تحقق وتؤكد ذلك المفهــوم

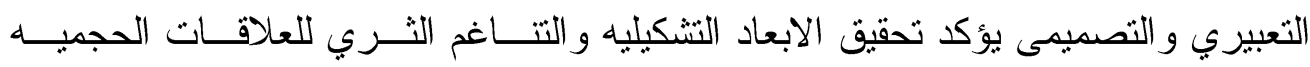
و الحلول النحتيه وقيم الفراغ المفتوح بين الكتلنين حيث تم تحقيق كل هذه القيم و الفرضــيات على اساس تأكيد فاعليه الخط الافقي للأرض بتكثيف التعبير ودعم فكرة وتصميم النصــبـ بشكل عام و هنالك نوع اخر من النصب التذكاريه التي يعتمد تصميمها علي الخط الافقي لســطح الأرض ولكن بحلول وابعاد معمارية صرحية تجمع بين العنصر المعدــاري الصــرحي بحلوله المتتوعه و بين المجسمات النحتيه التشخيصيه الرمزيه وهذا النــوع مــن النصــب 
التذكاريه بفضل اقامتها خارج المدينه أو على مشارف المدن أو في مو اقع الاحداث ذاتهــا

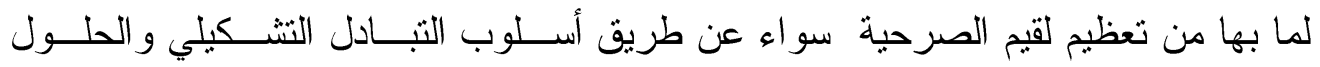
المعماريه أو بو اسطه تعظيم الحجوم و الارتفاعات كى يحقق النصب الغرض المقام من اجله

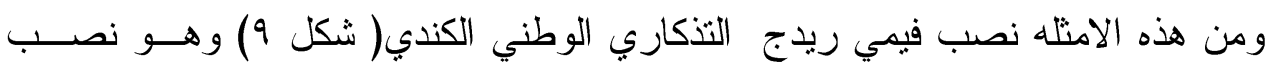
تذكاري للحرب يقع على بعد نحو ثمانية كيلومنزات شمال الر أسي في فرنسا بالقرب مــن

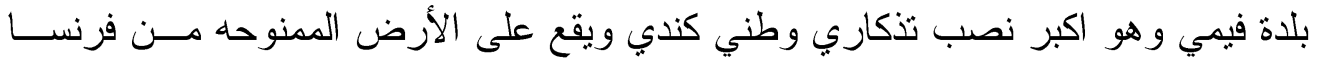

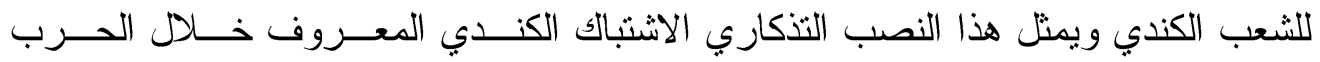

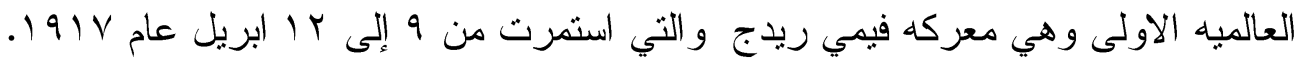

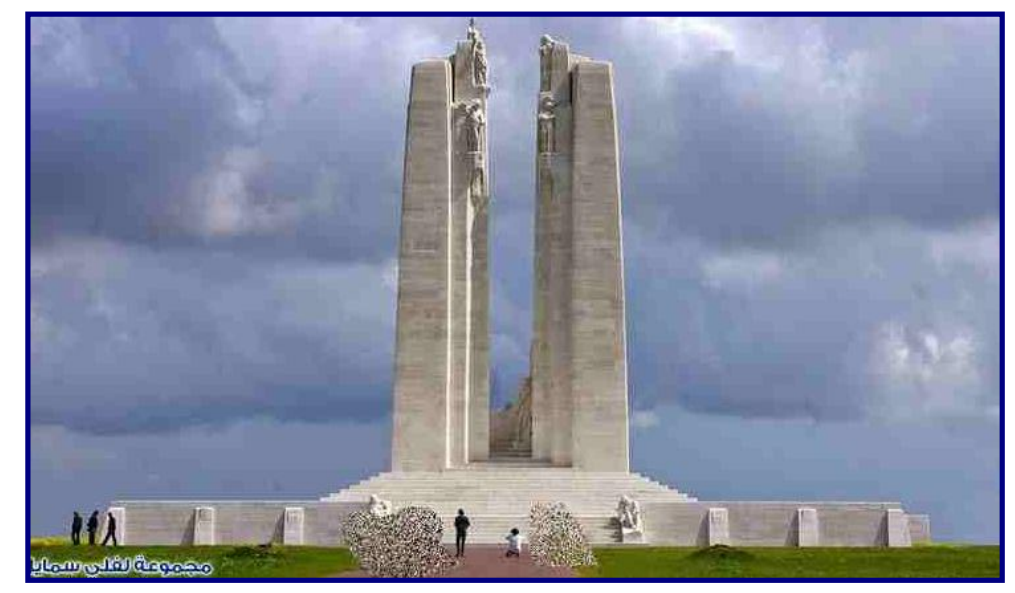

(شكل 9) النصب التنكارى فيمى ريدج بفرنسا ، وقا تم تصميمة على أساس الجمع بين العناصر المعمارية

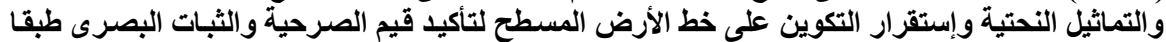

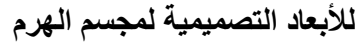

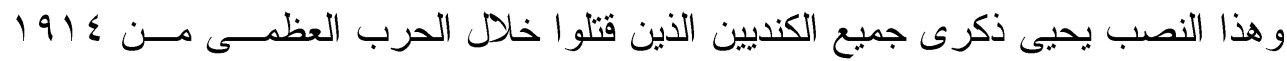

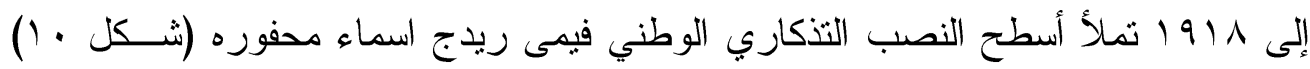

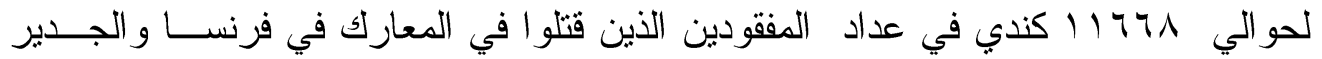

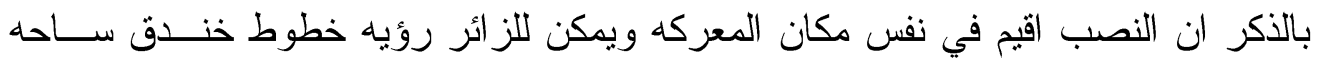
معركه الحرب العالمبه الاولى وقد قام بتصميم هذا النصب التذكاري (و التز سيمور الـــوارد

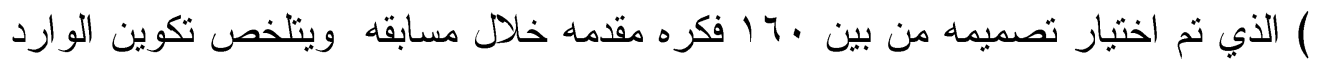
من اثثين من الاعمده يبلغ طولها ــ مثر و التي تمثل كل من كندا فرنسا. 


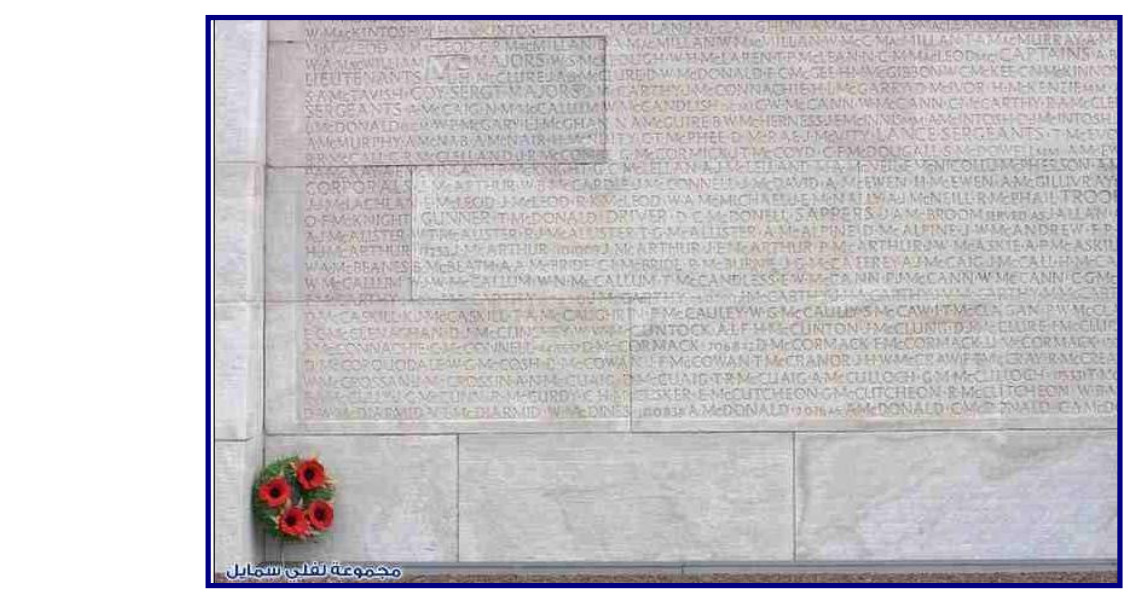

(شكل · 1 ) الأسماء المحفورة بأسطح النصب المعمارى والتى تحصر أسماء المفقودين الذين قتلوا فى المعارك

في حين ثم إضافة عدد من التماثيل التشخيصيه في اماكن مثتوعه من النصب و التي

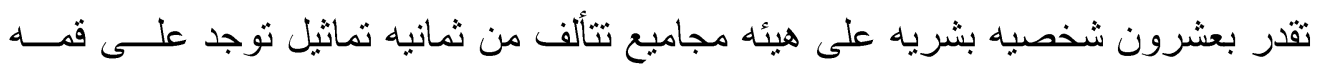
العمودين · (شكل (1) برو)

وتدعى الكورس تمثل العدالة و السـلام و الامل و الاحسـان و الشــرف و الإيمـــان و الحقيةــة و المعرفة و المجمو عة الاخرى (شكل r ( ) تدعى روح التضحية و تتألف من تمثالين لجندي متوفي يمرر الثعلة إلى زميله وتقع بين العمودين. في حين تضم مجموعتين من التماثبـلـل

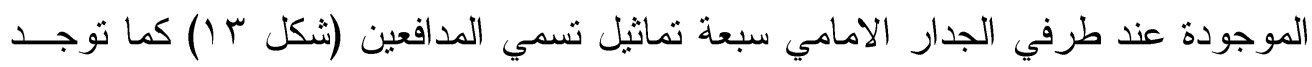
مجموعة من ثلاثة تماثيل تسمى كسر السيف في الزاوية الجنوبية مــن الجــدار الامــامي ومجموعة اخرى من اربعة تماثيل تسمى تعاطف الكنديين البائسين توجد في الركن الشمالي من الجدار الامامي فوق كل مجموعة توجد فوهة بندقية مع فروع الغار و الزيتــون و التــي • مثنل السلام اما البناء التصميمي للنصب فقد بني على اساس استقراره على خط الأرض الافقـي باربعة جدر ان معمارية بارتفاع ه.rمتز ثقريبا ـ قد تـم معالجتهــا بتوزيــع عـدد مــن المقصور ات الر أسية والمائلة (شكل 9) و عدد من المجموعات النحتية التشخيصـية لشـــل مساحة الجدار في حين ان الزاوية الامامية الرئيسية قد صمح مجموعــة مــن المسـتويات المتصاعدة تدريجيا بالسلالم حتى تصل إلى مساحة مربعة تبدأ منها اســتمر ارية وصـــود و استقرار العمودان اللذان يحصر ان فيما بينهما فراغ بيني مفتوح تتاسب قيمته مع الكتلنين

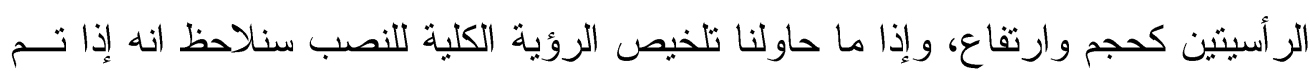
رسم خطوط وهمية تبدأ من اطر اف مساحة الجدار المربعة منتهبة إلى اعلى نقطة هرمبــة 
وبحيث تمس تلك الخطوط الوهمية نهايات النصب من أعلى حيث يقـع التصــميم بكامـلـل

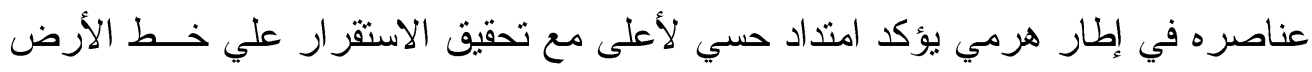

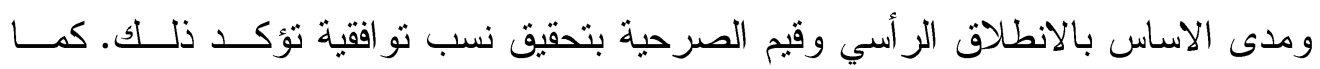

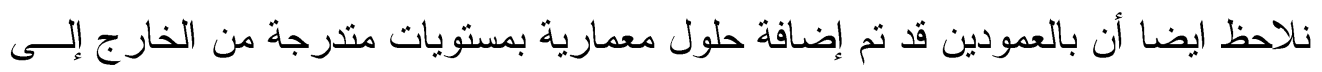

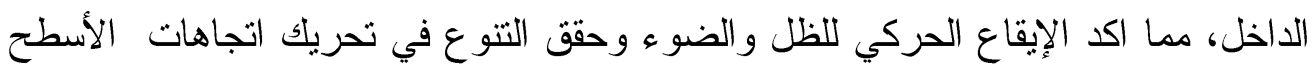

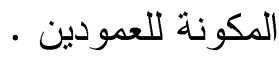
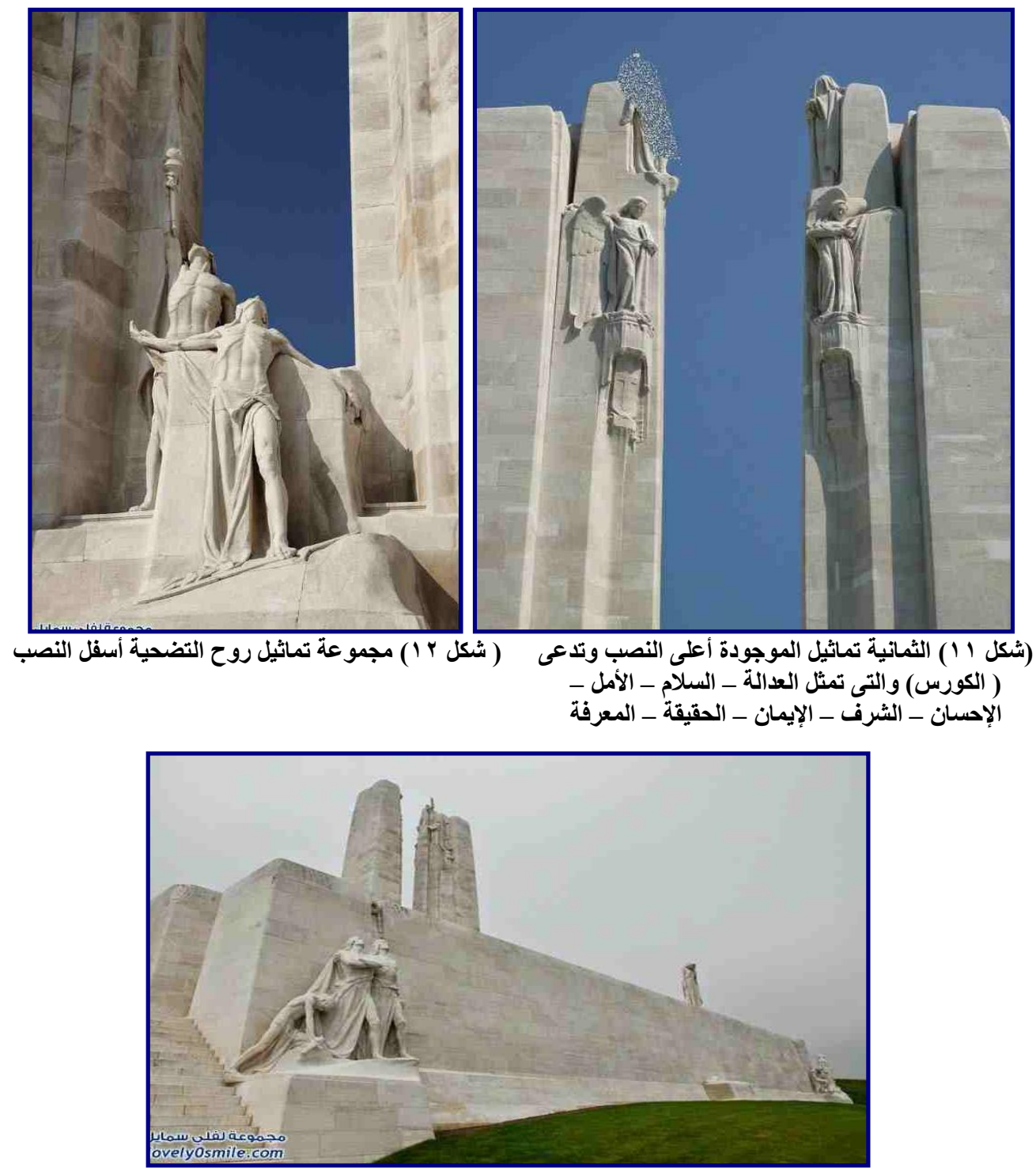

(شكل س I ) مجموعة تماثيل الددافعين والموجودة عند طرفى الجدار الأمامى 
في حين تنتهي الاعمده بوجود ثمانية تماثيل تثخيصيه بمعالجه وأسلوب نثكيل يتاغم

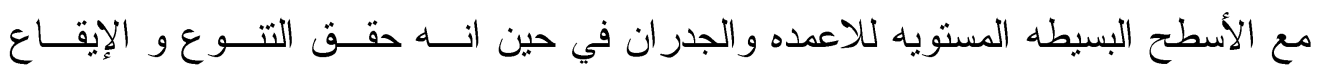

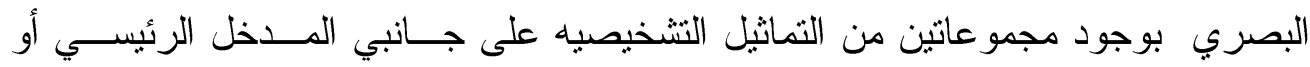

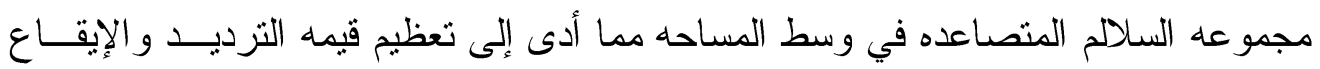

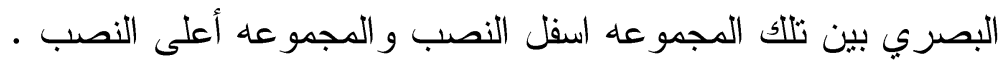

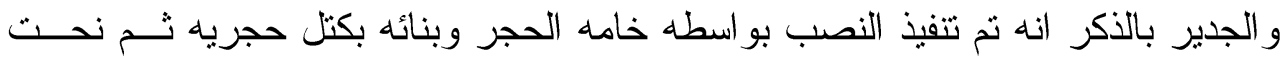

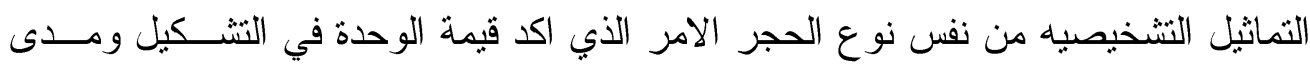

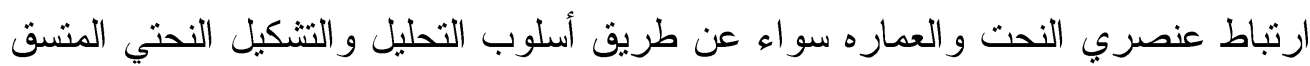

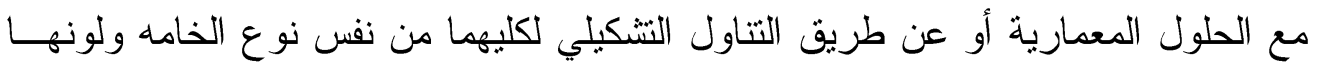

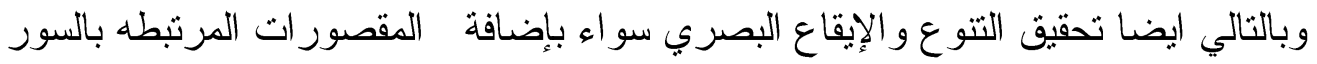

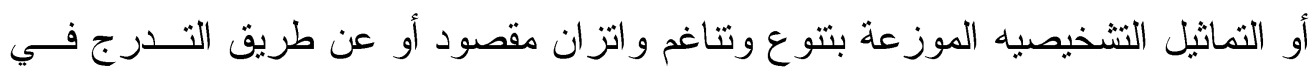

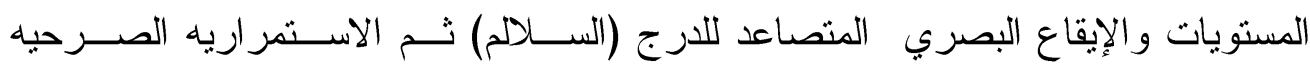

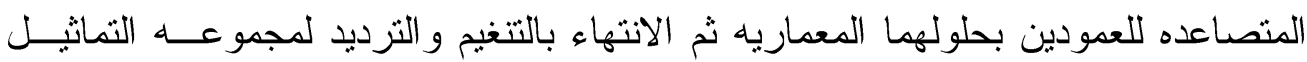

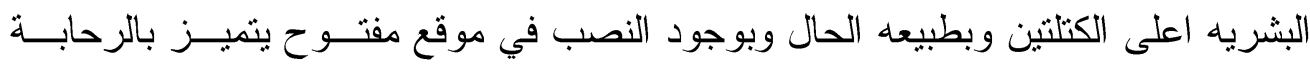

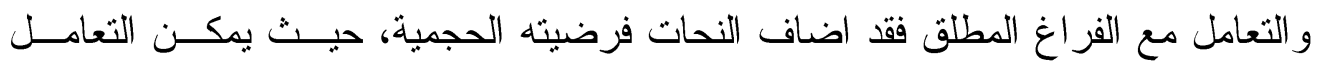

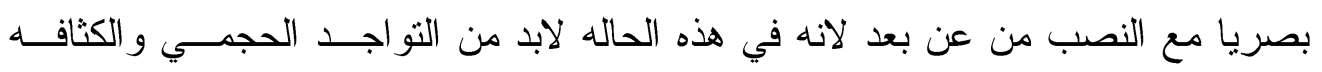

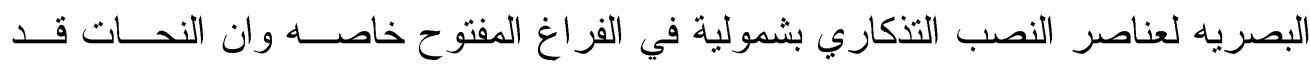

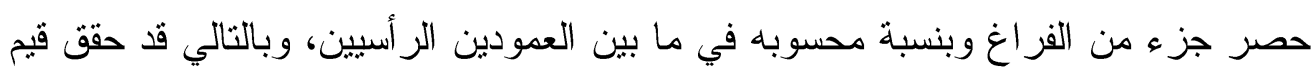

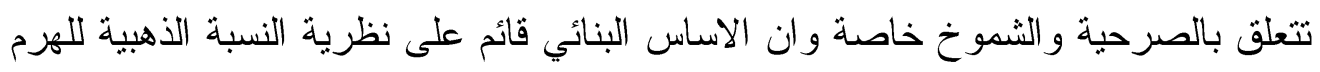

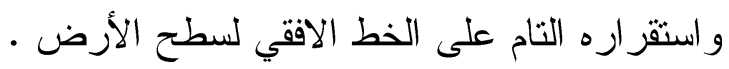

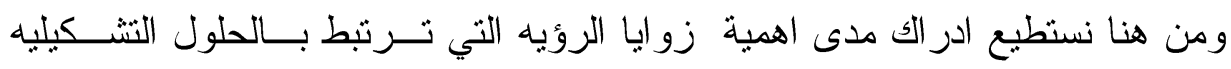

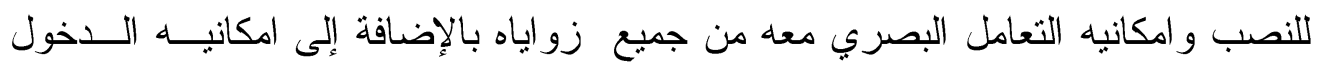

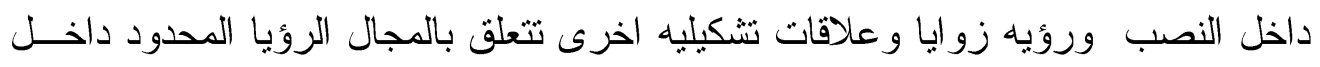

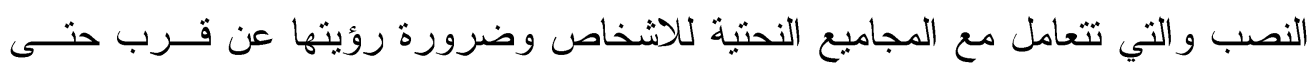
تصل الرساله أو البعد النعبيري المتعلق بموضوع القامه النصب من اجله . 


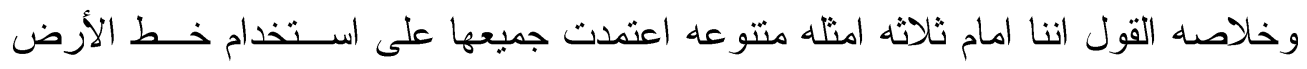
المسطح الافقي في تأكيد الابعاد النتكيلية و التعبيريه كما اعتمدت ايضا على تمثيل العنصر البشري في النحت لتأكيد الجانب التعبيري سواء في أبطال كالييه التي اقتصر الفنان علــى

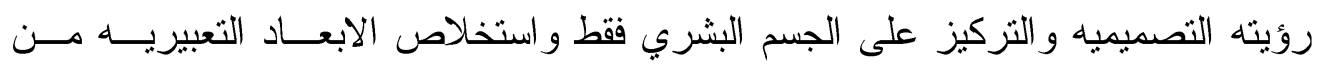
عنصر الحركه و تعبير الجسد باكمله وتعبير الوجه الإنساني وبما ان الأحجام تقترب مــن الأنس

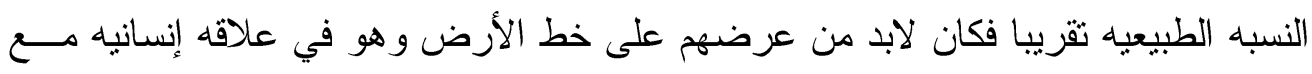

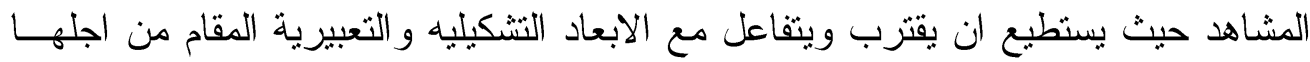
ذاللك النصب في حين انه في النصب التذكاري للوقت فقد عظم النحات من ضخامه العنصر البشـري

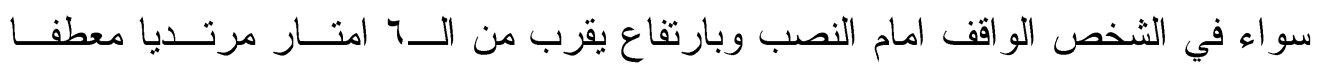

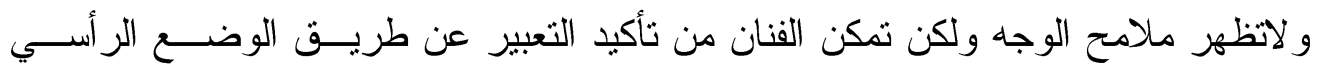

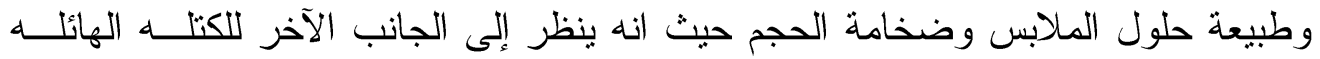

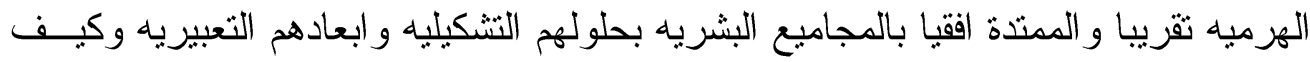
فرض أحجام معينه ثرتبط بمنسوب الرؤية حيث عرضهم على قاعده هندسيه متدرجه مــن

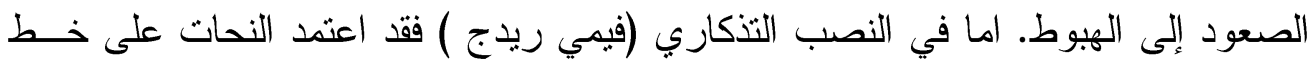
الأرض ايضا و انما شارك العنصر المعماري الصرحي في تشكيل النصب مـــع العنصــر البشري نظر الطبيعه الموقع ومدى الرؤية المسافي و المحيطي للنصب ولذلك فقد عظم مــن

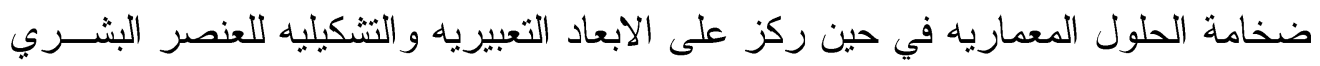

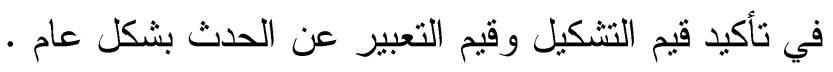

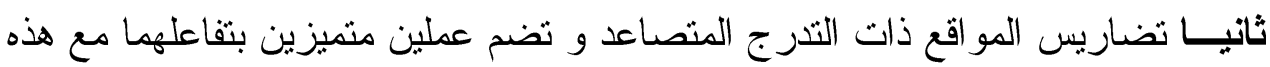

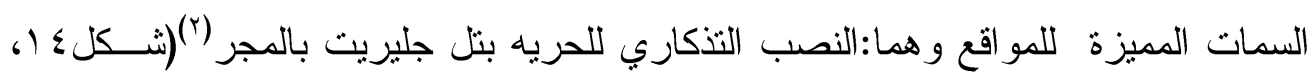




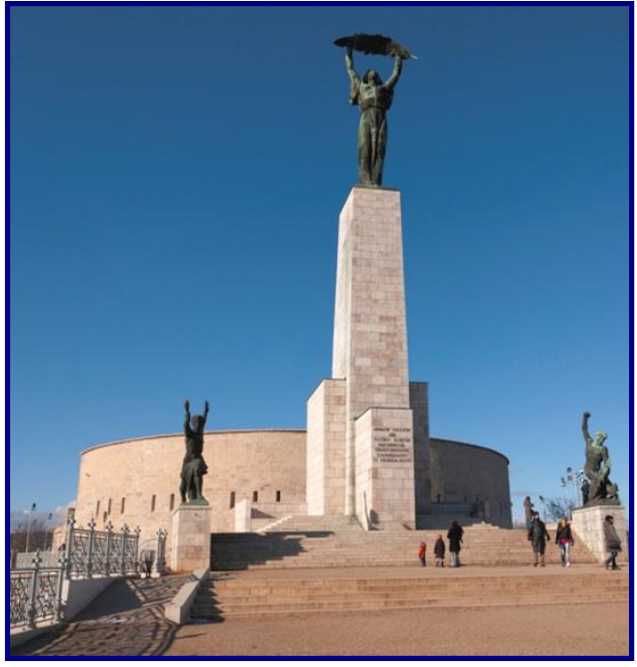

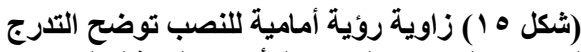

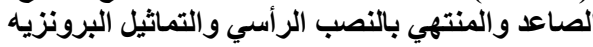
على جانبى النصب النصب

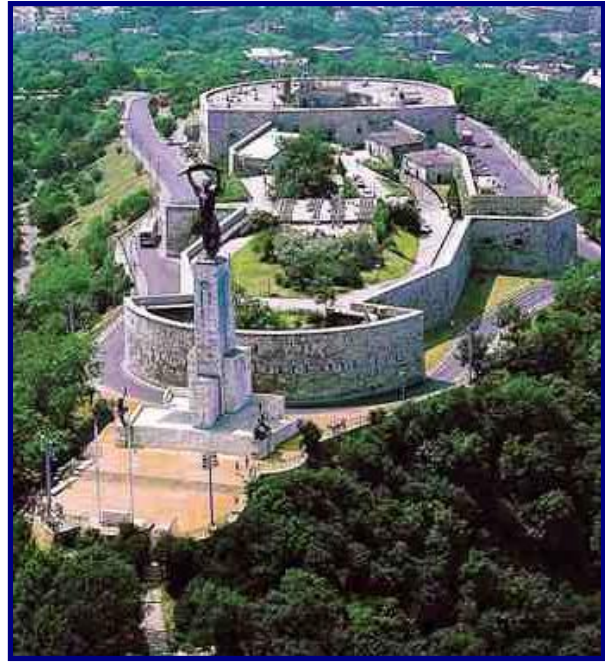

(شكل \& 1 ) النصب التذكارى للحرية بتل جليريت بالمجر

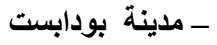
النصب التذكاري بثل جليريت احد معالم مدينة بودابست البارزة نفذ من قبل (مبكلــــ هورتي) حاكم المدينه كنصب تذكاري لابنه الذي توفى في حادث أثثاء الحــرب و عنــدما وصل الروس استبدلو المروحيه التي كانت بيد ثمثال الفتاه اعلى النصــب بســـف نخبـلـل

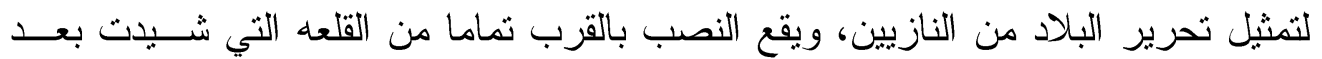

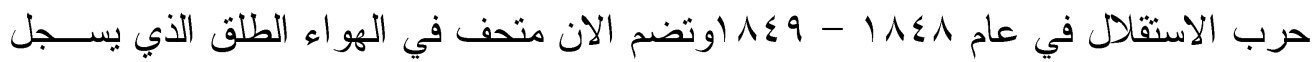
تاريخ الثل. (شكل 1 ( ) - (ش)

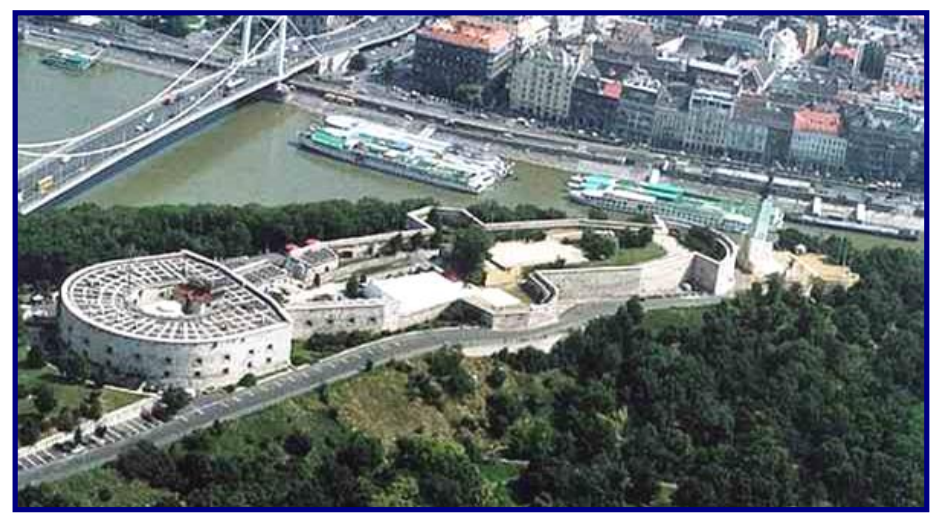

(شكل 1 ( ) زاوية روئة لتل جليريت ، وقد إرتبط تصميم النصب بتصميم القلعة والمتحف الذى يسجل تاريخ التل

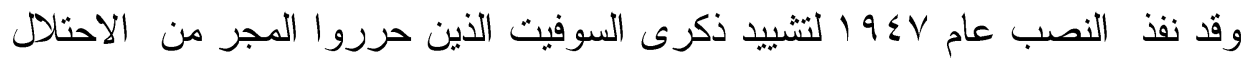

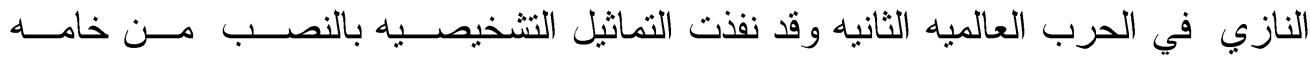
البرونز حيث يبلغ طول التمثال اعلى النصب فقط ع ا م (شكل V ) ) ويستقر على قاعده قد تم تشكيلها بكتل حجريه بارتفاع بrم وقد كتب على النصب عباره (نصبته الامه المجريه 
الممنونة للأبطال الروس الذين حرروها ) و على مر السنين تحول الاحساس بالعرفان ناحيه

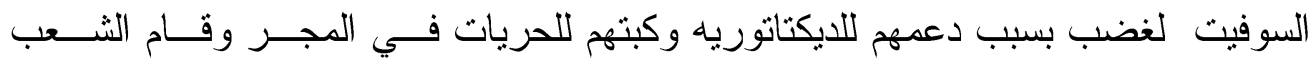
المجري بثوره ضد السوفيت عام 1907 ولكن لم تؤني ثمار ها.

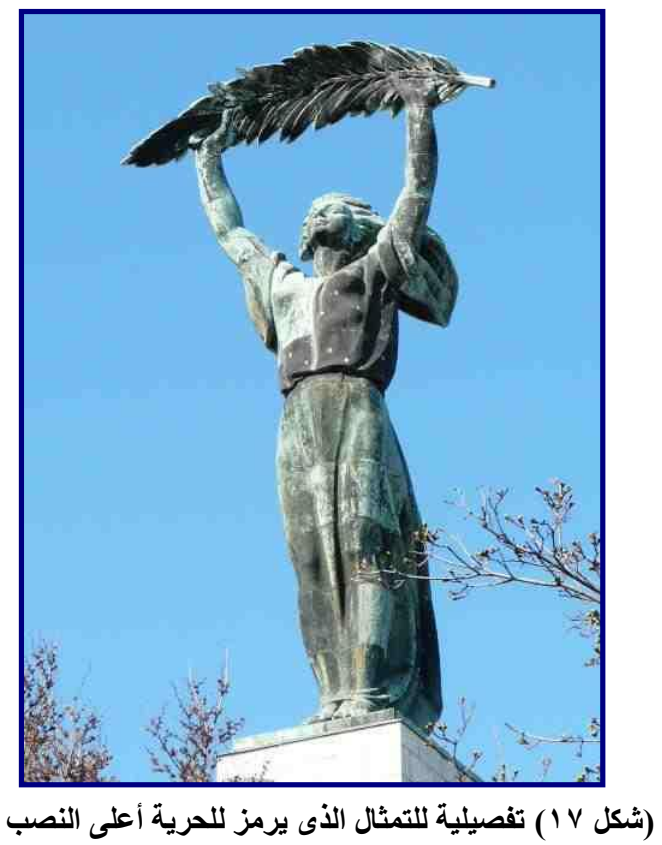

وبعد انهيار الاتحاد السوفيتي ومبدا الثيوعيه اقيم النظام الديمقر اطي سنه 919 19 ولذلك فقد تم تغير العباره و اصبحت ( في ذكرى كلا من ضحو ا بحياتهم من اجل استقلال وحريه

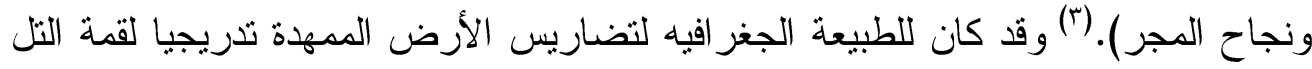
دور أساسي في إقامه كلا من القلعه و النصب على حد سو اء قد استغل المعماري و النحسـات تلك الطبيعة المتدرجه وبنى فكره التصميم على هذا الاساس خاصة امام النصب التـــاري فقد تمهيد المستويات المندرجة و الصاعدة بمساحات ذات مستويات تقصلها مجموعــة مسـن الدرج حتى الوصول إلى بداية النصب (شكلم/ (الذي يحتوي ايضـا على مســتوى اخــر

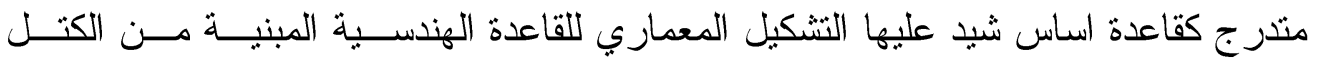
الحجرية و التي تتسم بأسلوب التشكيل القائم علي تداخل الكتل الهندسية بارتفاعات و حجوم

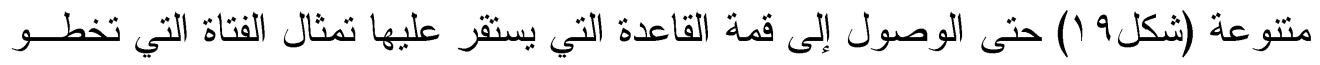
خطوة إلى الامام رافعة بيديها سعف النخيل وقد تلاحظ أسلوب المعالجة التشكيلية للتشثـال $\left({ }^{3}\right)$ www.arlkipedio.org 


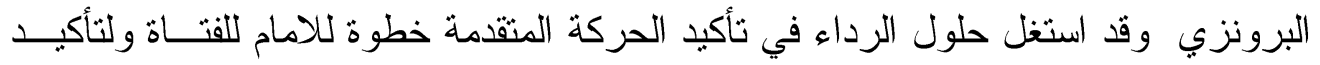
قوة الثد و الجذب و استغلال ذلك بحلول نشكيلية ذو نقلات حادة لتفعيل تاثثر الضوه و والظل الو اقع على جسم التمثال كى يساعد على ظهور و إدر الك التفاصيل عن بعد .

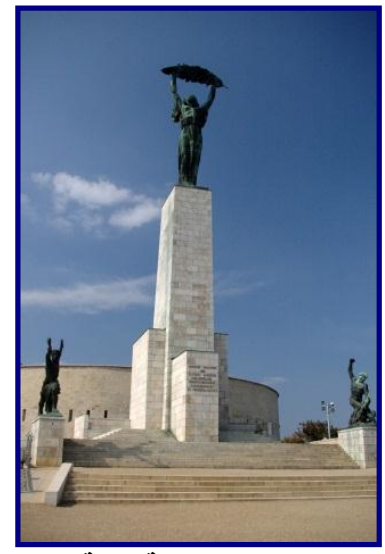

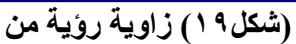
المستويات الصاعدة تدريجيا نحو من

النصب

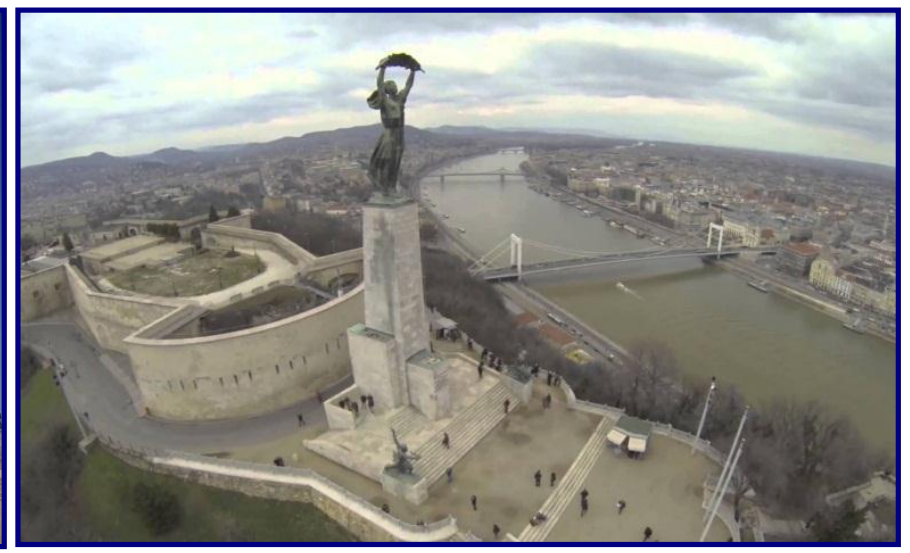

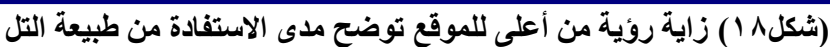

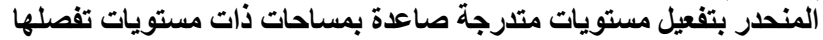

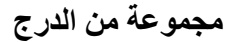

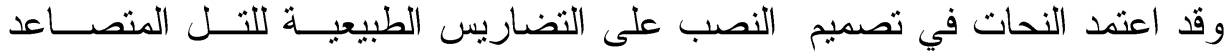

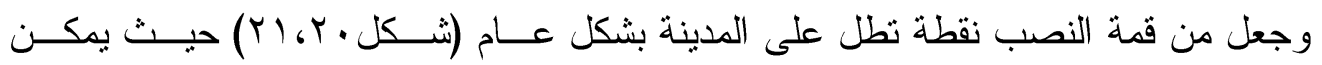
مشاهدة النصب من اي مكان في داخل المدينة حيث يقع التل بالقرب مــن ضـفـاف نهـر

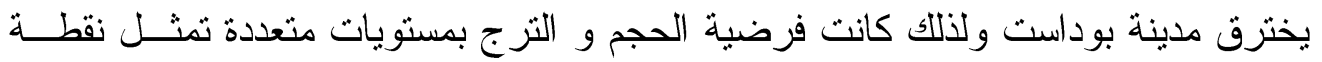

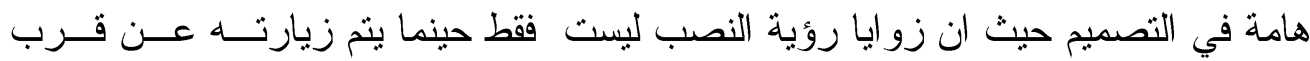

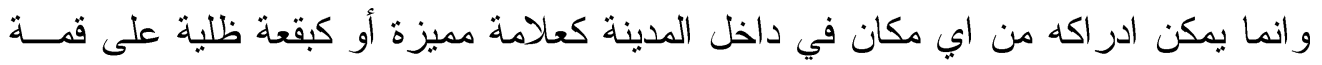

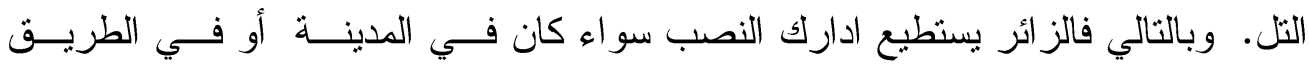

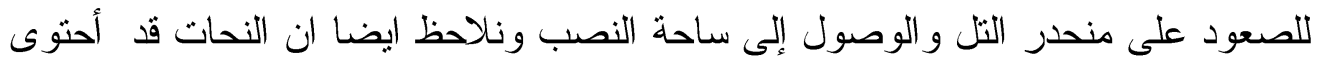
السور الدائري للقلعة وبني تصميمة على اساس ان يكون السور هو خلفية مكملة للنصب حيث افترض الحجم والارتفاع بحيث يتتاسب ارتفاع النصب مع ابعاد الخط الافقي للســور

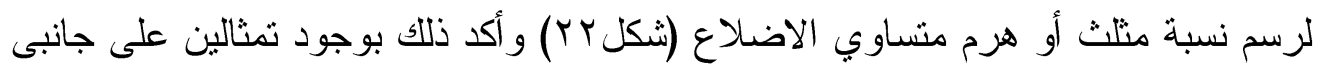
المستوى الاخير يقعان على نقطي الخط الافقي للمنلث كما أكدها بتتفيذهما بخامة البرونز

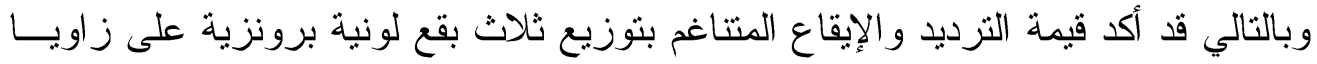

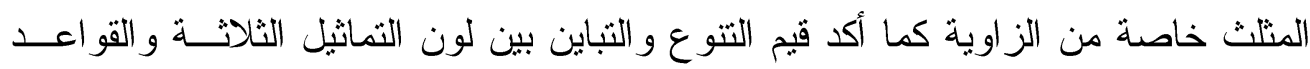

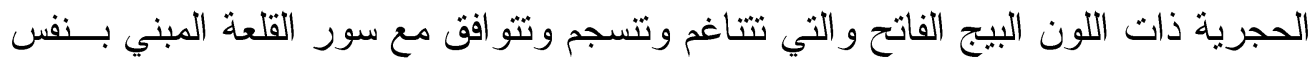


الأسلوب وبنفس الحجر وبذلك قد حقق النحات قيمة الوحدة العضوية والتتاغم و التتاسق مــع مكونات الموقع المعمارية وطبيعته الجغر افيا .

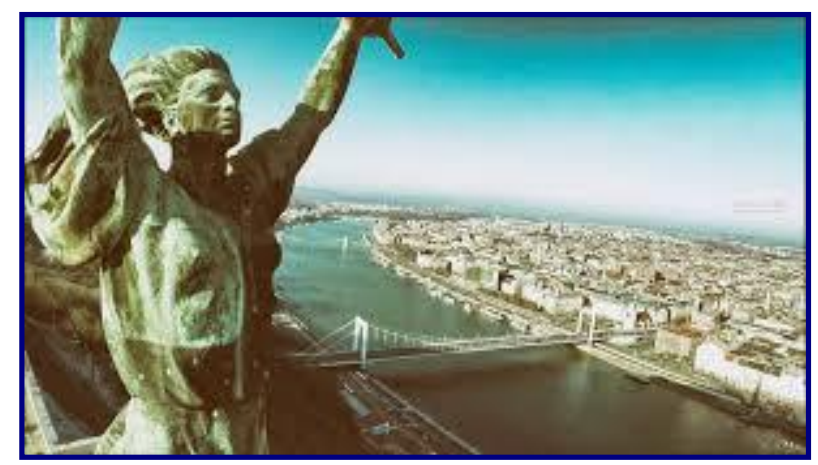

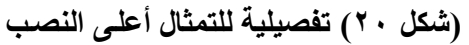

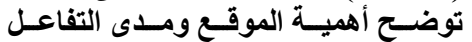
البصرى معله من أى مكان فى المدينة

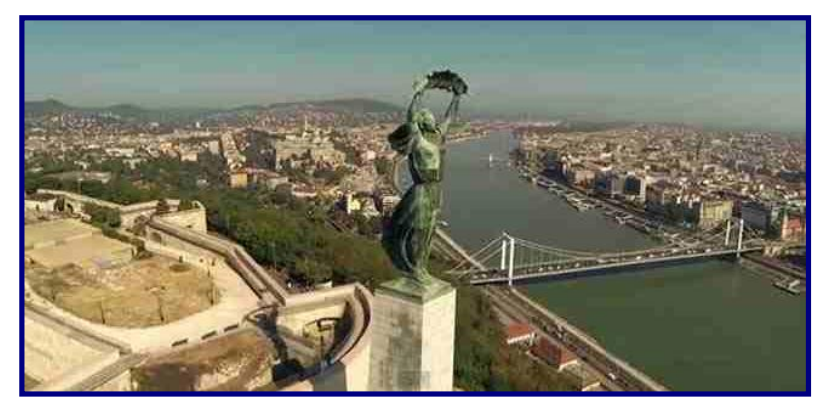

(Y) (شكل)

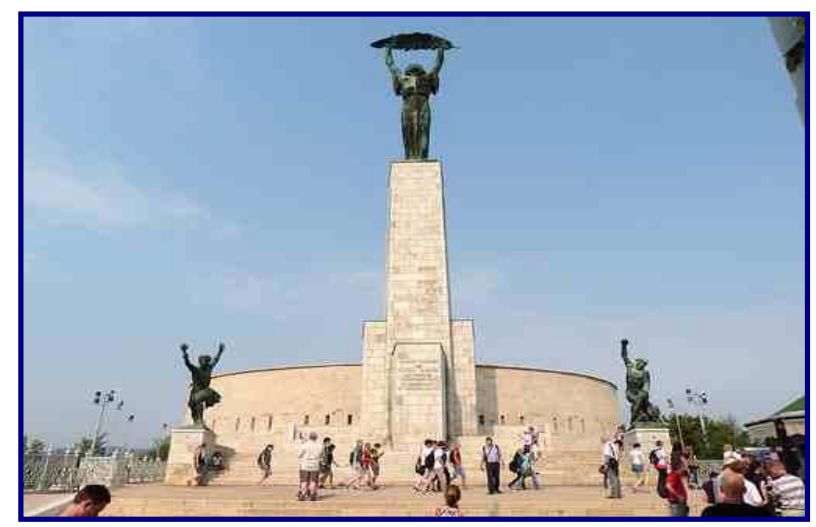

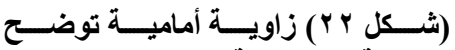

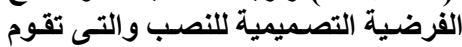

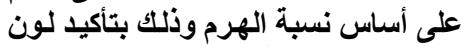

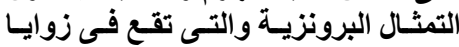

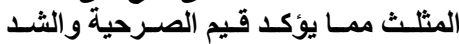
الفراغي بين العناصر النحتية.

و من الامثلة الو اضحة للنصب التذكارية التي اعتمــد تصــميمها علـى طبيعــة الأرض المتذرجة في تصاعد نصب (الوطن الام أو نصب ماما بيف) (شكل r) وهو تمثـال بقـع على اعلى هضبة مرثفعة هي هضبة ماما ييف كوردان- التي تطل على مدينة فولجوجر او (ستالينجر اد سابقا) في روسيا تكريما لمعركة ستالينجر اد التي جرت بين الاتحاد الســـوفيتي 


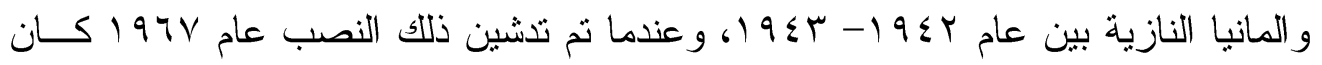

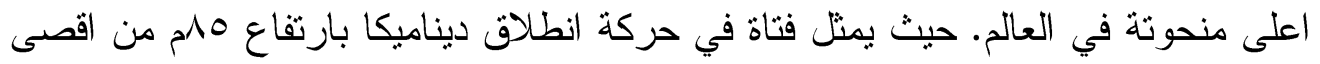

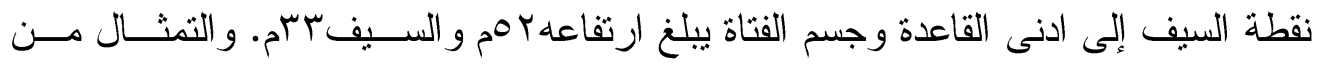

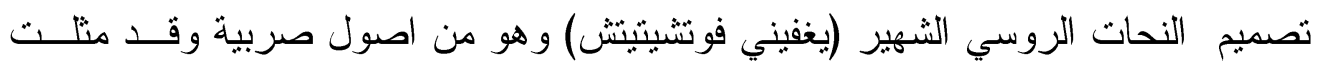

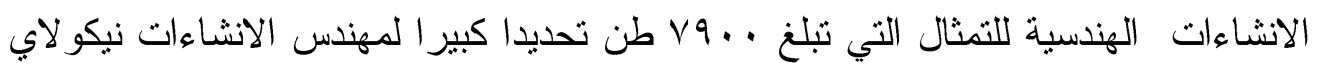

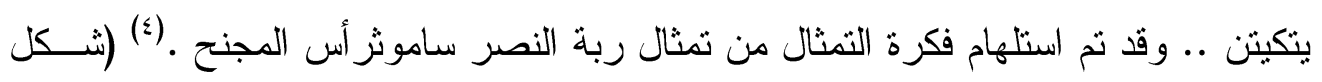
( $r \varepsilon$

ومن الملاحظ ان النحات قد بنى أيضا فكرته التصميمية و التعبيرية للتمثـــال الضــخم

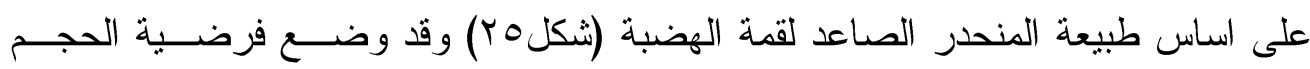
و الارتقاع كاساس ايضا في تأكيد فكرته التصميمية والتعبيرية بالمبالغة في الحجم و انتشـار

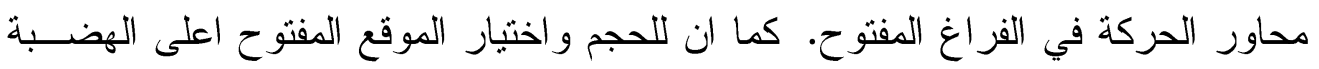

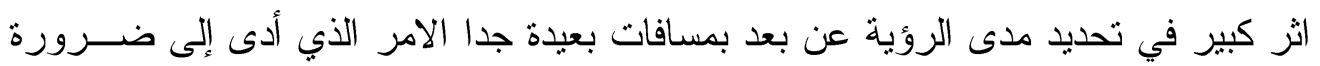

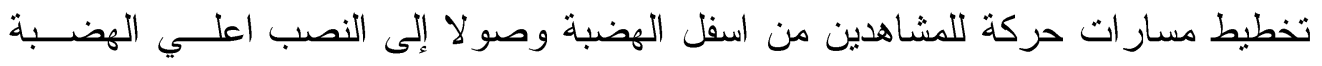

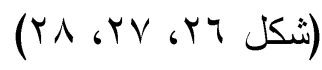

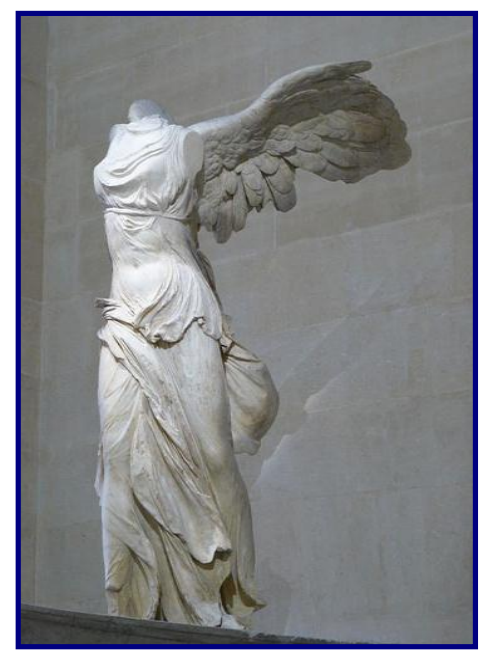

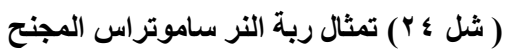

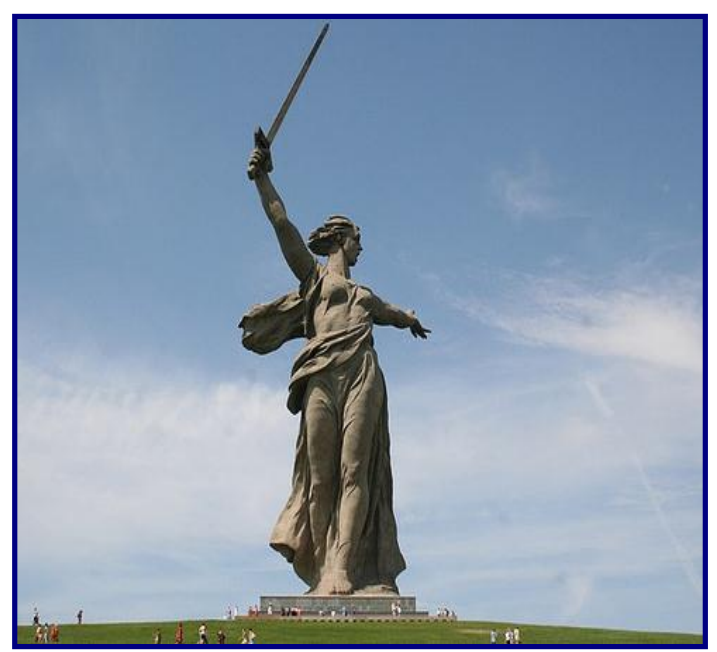

(شكل ب ץ) زاوية أمامية للنصب التذكارى ( الوطن الأم ) على (شلى هضبة تطل على مدينة فولجوجراد ( ستالينجراد) سابقا

$\left(^{4}\right)$ www.beladitodey.com 
ويتسم التمثال بان محاور الحركة في الفراغ ذات إيقاع ديناميكي وفي حالة الاندفاع إلى الامام ترفع يدها اليمنى سيف يتجه محور حركته عكس اتجاه اندفاع التمثال في حين أيضا

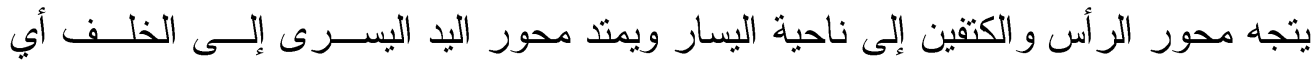

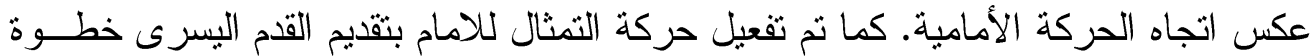

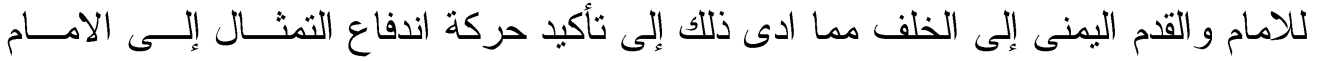
وتحقيق قيم الاتزان الحركي حيث لعب تشكيل الرداء دورا هاما في تحقيق الإيقاع الحركي الديناميكي و اتزان الكتلة الضخمة في الفر اغ المفتوح •

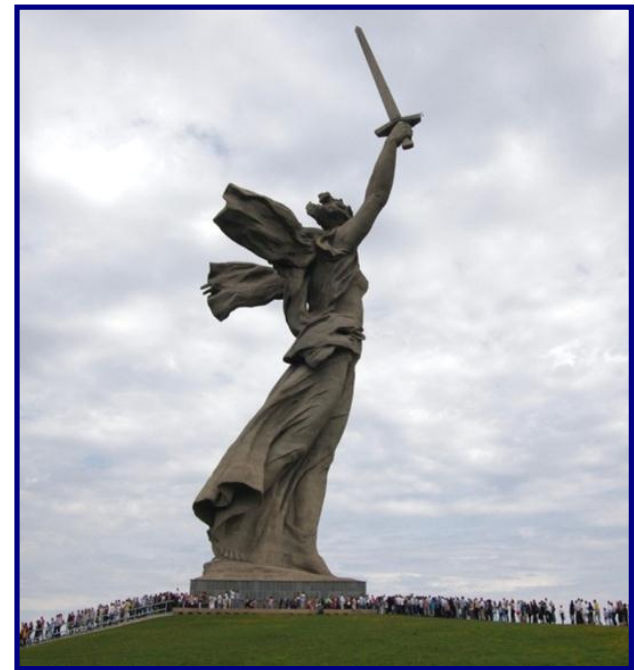

( شل צ ץ ) زاوية جانبية للتمثال توضح فاعلية الحركة الايناميكية ومدى حضور وانية وضخامة الحجم فى الفراغ

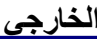

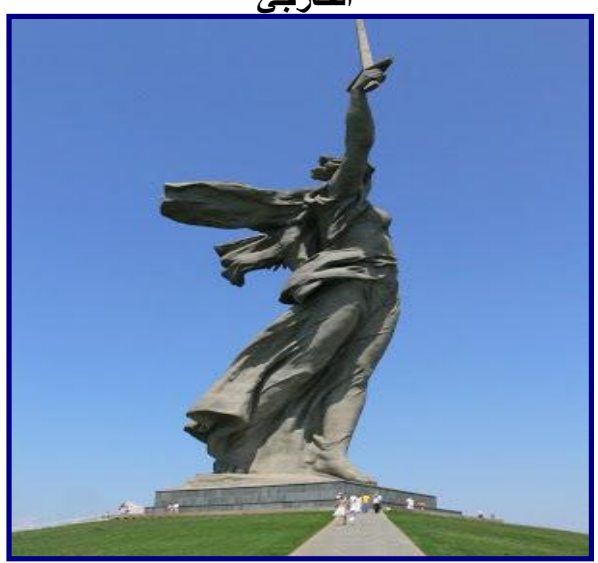

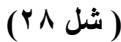

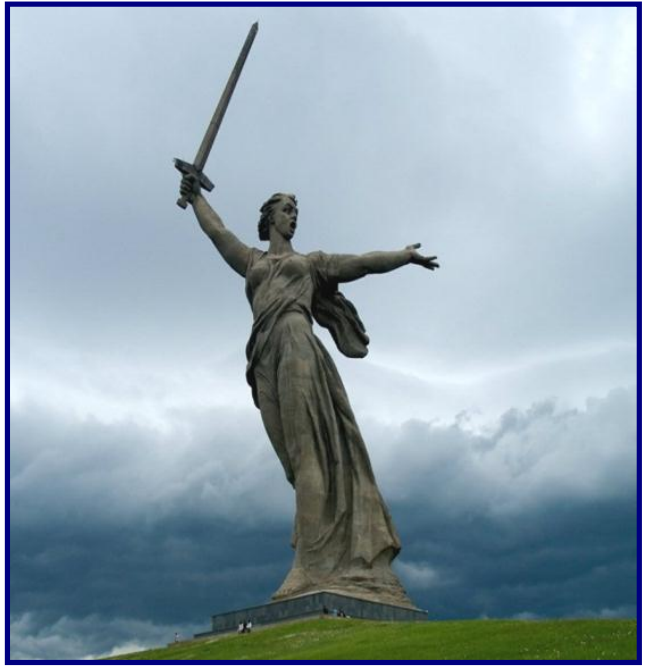

(شكل • ب) زاوية جانبية للتمثال توضح محاور الحركة وتفاعلها ميع الفراغ المحيط

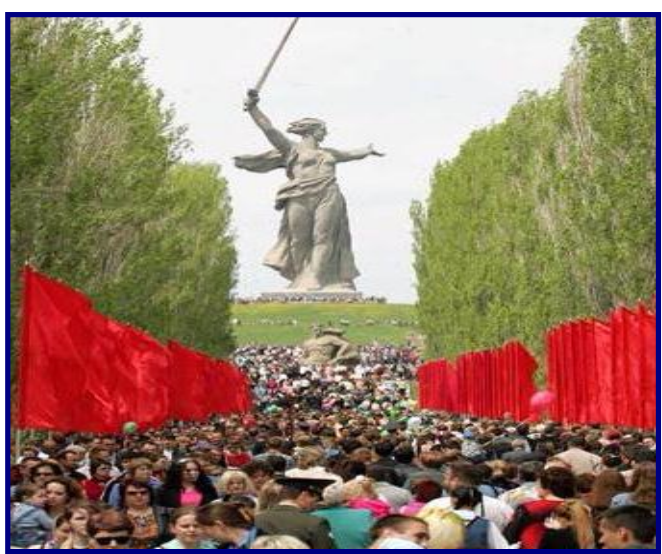

(شكل (YV لقطة تنكارية يوم أفتتاح التمثال 


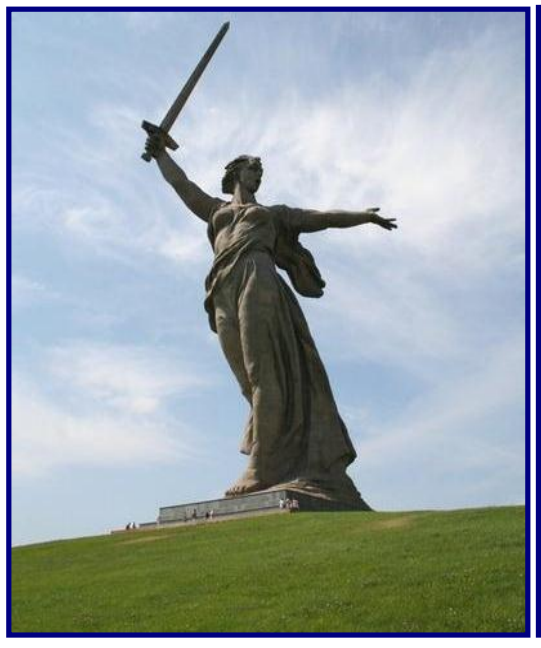

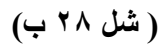

زوايا روية متعددة توضح إنتشار محاور الحركة وتفاعلها مع الفراغ المحيط

كما تضيف الحركة المندفعة احساس بعدم استقر ار التثثال وكأنه يهم بالخطوة فقد وفــق

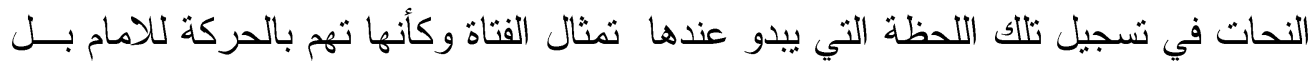
تتسامى إلى اعلى ايضا مما اكد ذلك الاحساس وجود الكتلة اعلى الهضبة المنصاعدة بشكل ممهذ جدا. كما ادى تتوع محاور الحركة في التمثال إلى تفعيل جميع زوايا الرؤية وتأكيد

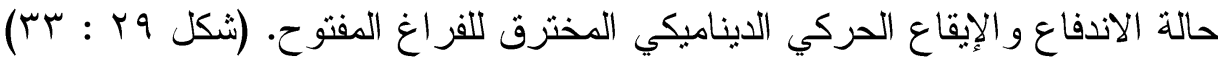

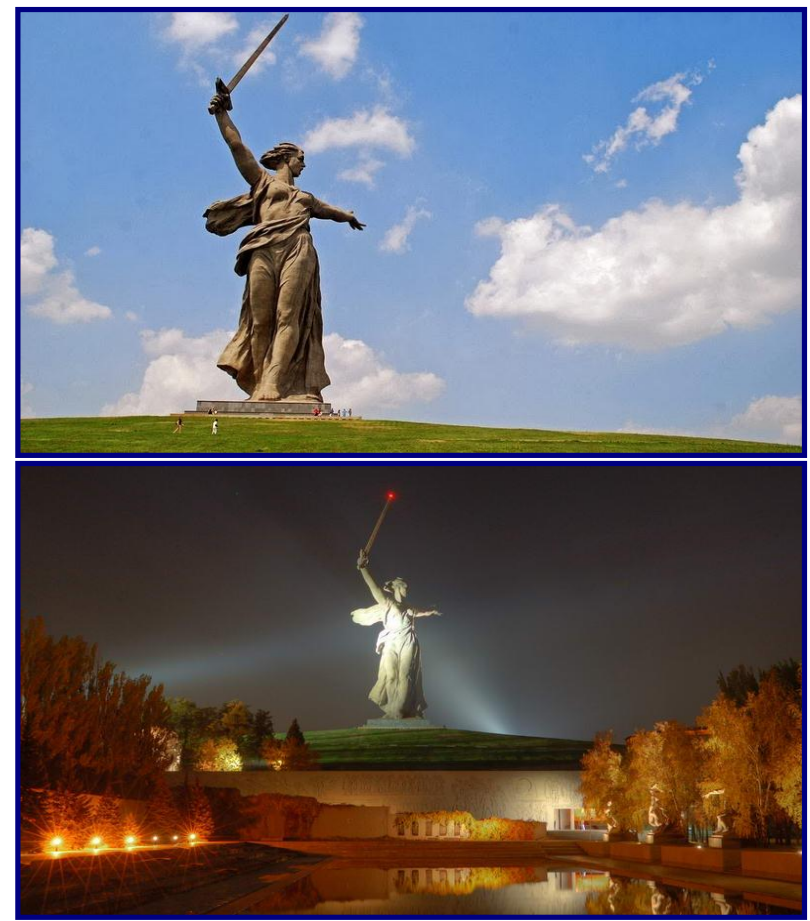

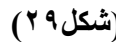

(شكل · مأثر الإضاءة الصناعية

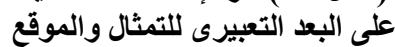

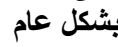




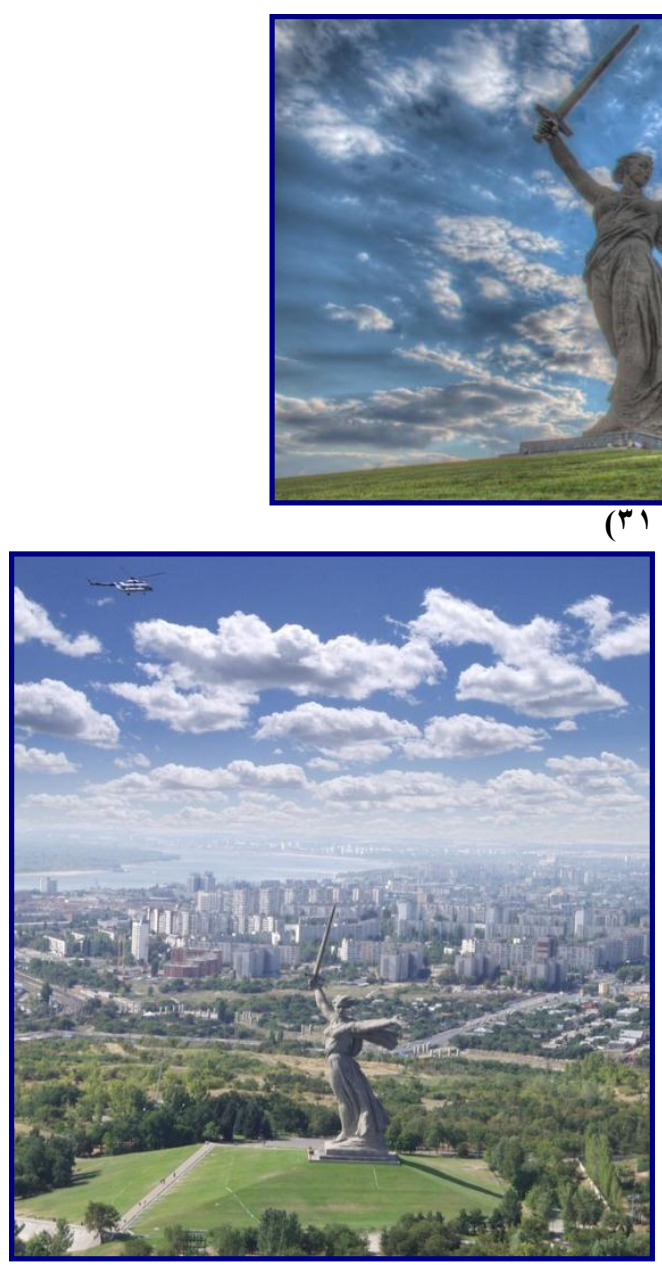

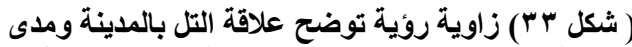

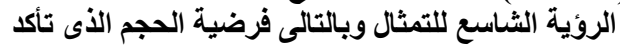

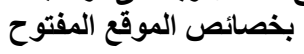

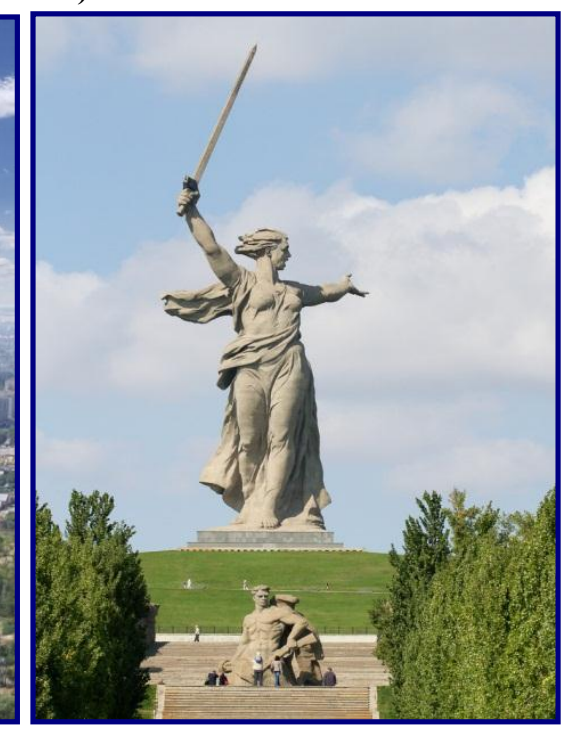

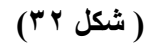

ثالثا مواقع ذات طبيعة جبلية

ويتم فيها البحث عن حيوية العلاقة التصميمية و التعبيرية بين الجبال و ما يتحد معهــا من نصب تذكارية ومنها : تمثال المسيح الفادي (شكل ع ب) وهو تمثال ضخم على طــر از فن (أرت ديكو) للسيد المسيح بمدينة ريو دى جانيزو ويعد رمز اليس للمدينة وحدها فقـ طـ بل للبر ازيل كلها و للمسيحية في العالم اجمع يبلغ ارتقاع الثمثال بس مثر (ه إقدم ) ويزن

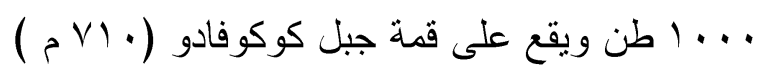




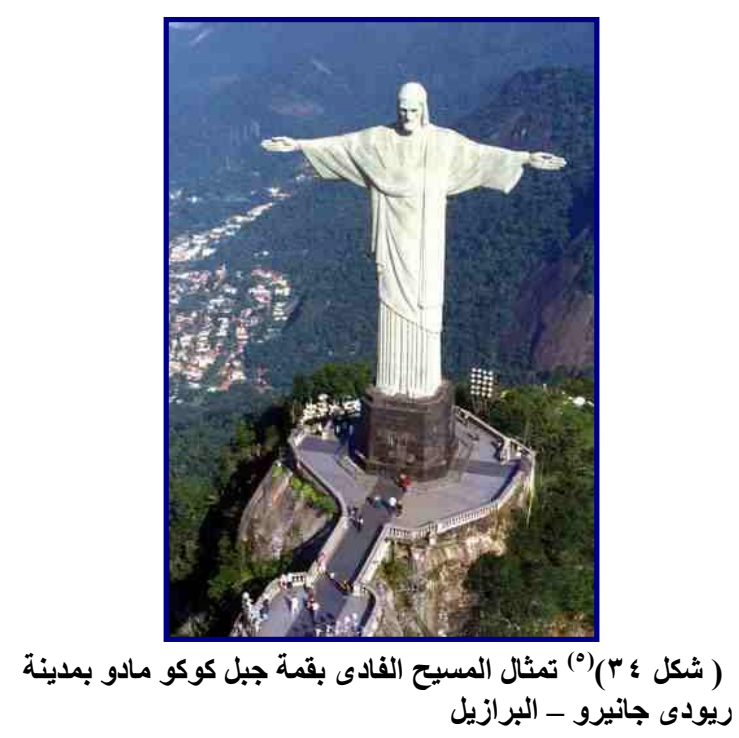

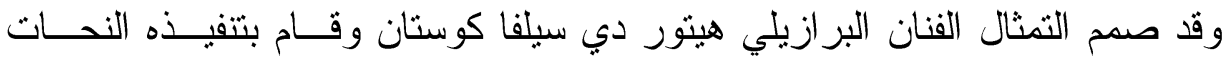
الفرنسي باول لاندوبسكي و التمثال يشرف على الحديقة و المنتزة القومية لغابة تيجوكا الاكبر

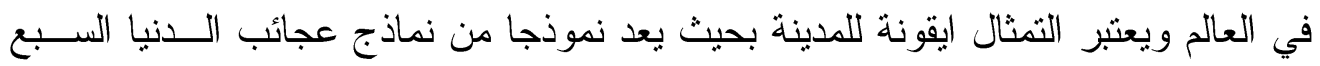

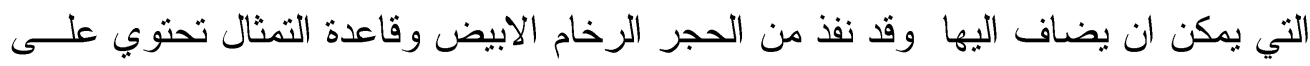
كنيسة رومانية كاثوليكية وقد تم الانتهاء من تتفيذه في با اكتوبر اسبو الو ومنذ ذللك التاريخ

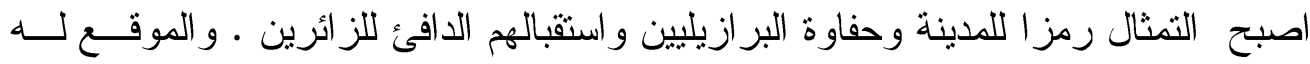
اطلالات رائعة على مدينة ريودي جانيرو و الخليج وجبل شو غارلوف و شاطئ كوبا كابانا

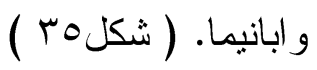

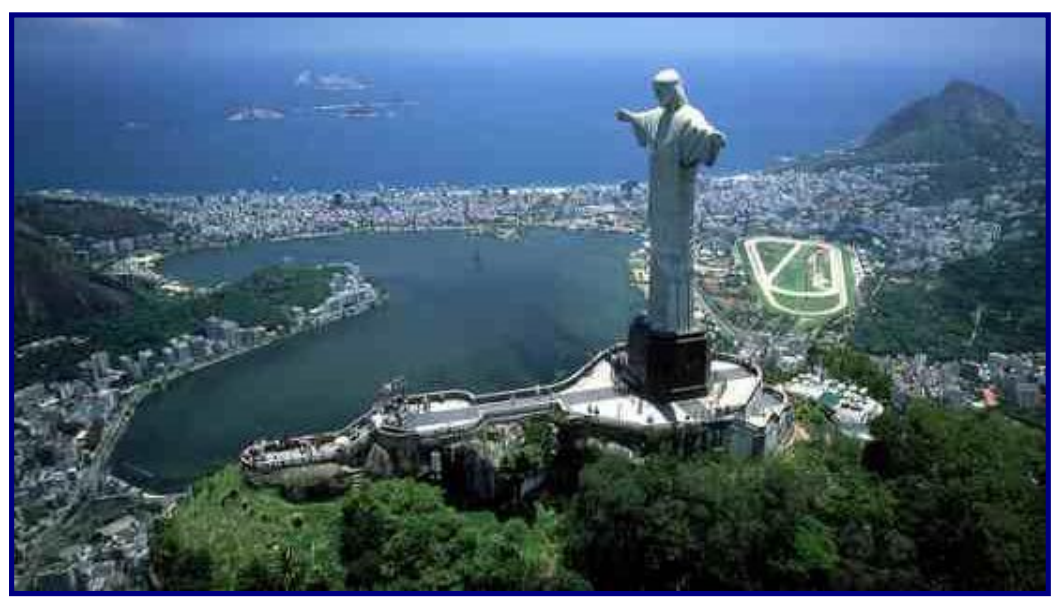

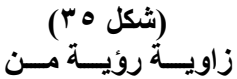
أعلى للتمثـال توضـح

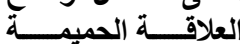

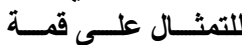
الجبـل ومـدى إدراكـهـ البصرى من أى مكان إلى فى المدينة

$\left({ }^{5}\right)$ www.ar.wikipedia.org 
ويعتبر اختبار النحات لموقع التمثال مرتبط بمفاهيم تخص مكانة المسيح عليه الســلام

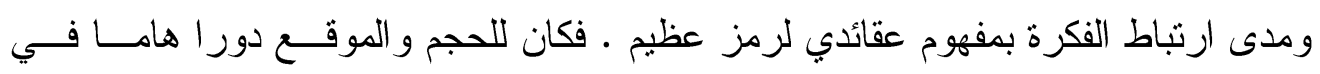

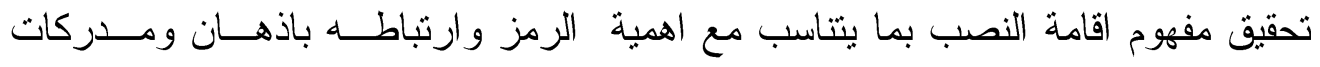

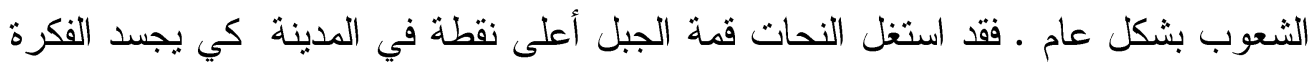

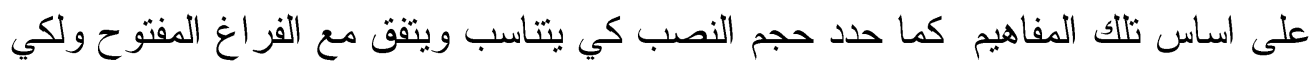

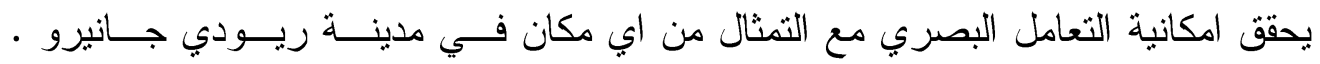
بالإضافة إلى امكانية الصعود فوق الجبل لممارسة الطقوس الدينية في الكنبسة أو لزيــارة النصب عن قرب الامر الذي جعل المصمم ايضا يدرك اهمية زو ايا الرؤية عن قرب ومهد

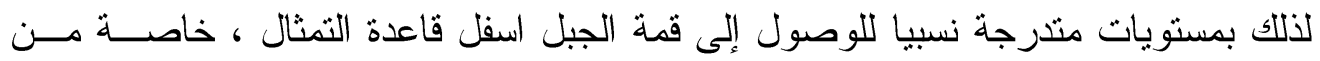

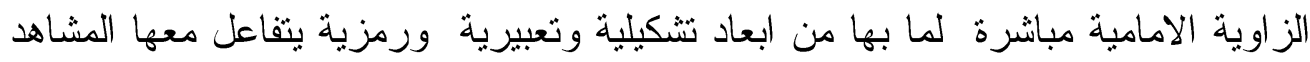

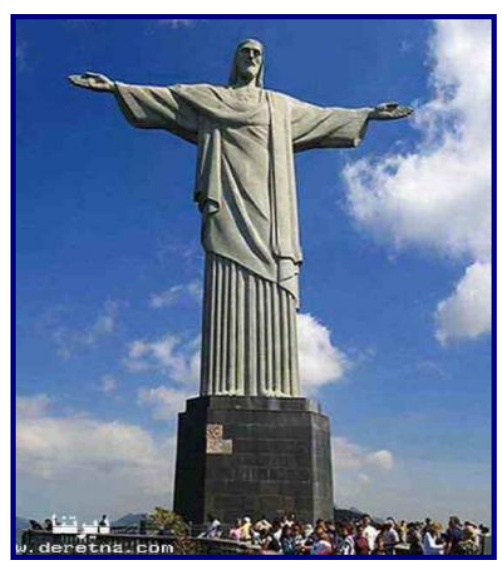

(

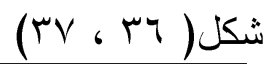

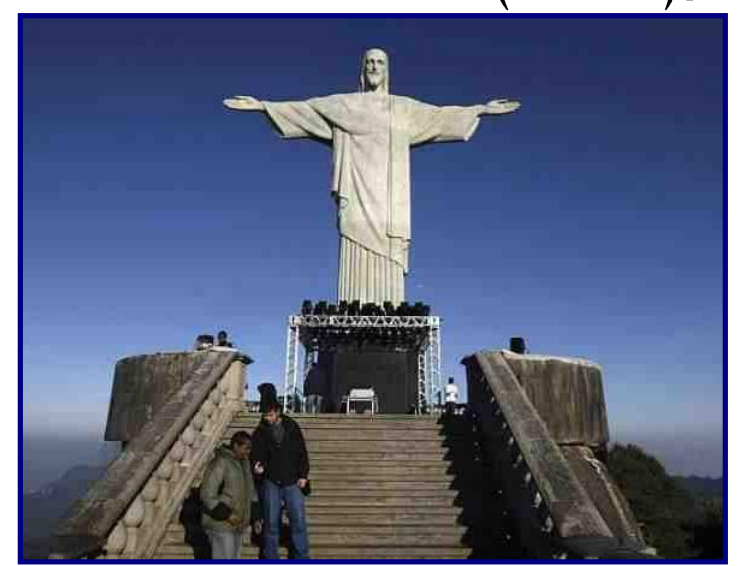

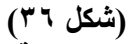

زاوية روية أمامية للتمثال تؤكل البعد التعبيرى والرمزى للنصب

ولذلك نجد ان تصميم التمثال بما يحتويه من محاور حركة محدودة تثمثل في اســتقامة

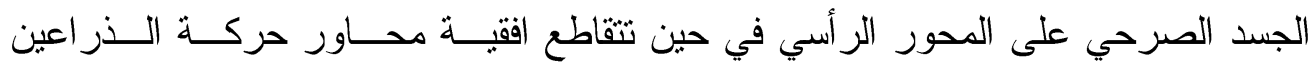

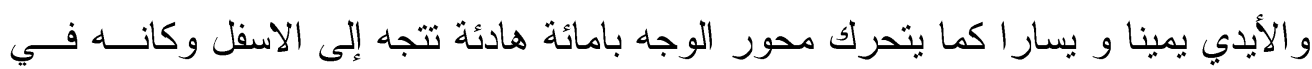

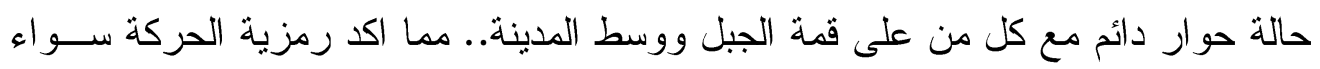

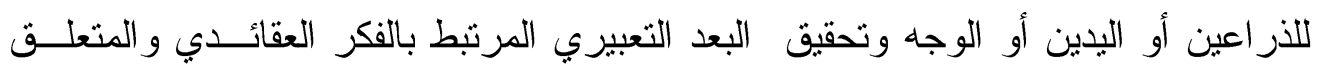

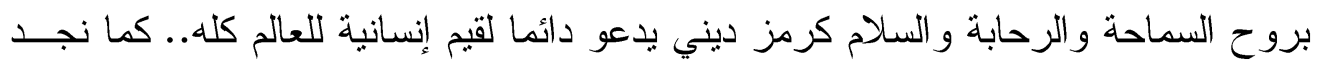

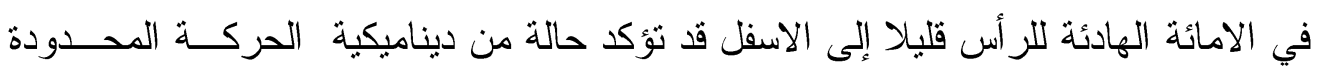


(حركة ساكنة) حيث ان البناء التصميمي قائم على علاقة المحور الرأسي للجسم الو اقف في

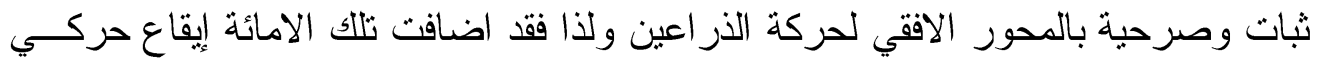
عميق الاثر بحيث يحدث ديناميكية حركة باطنة تثفاعل مع السكون المستشــعر مــن بنــاء

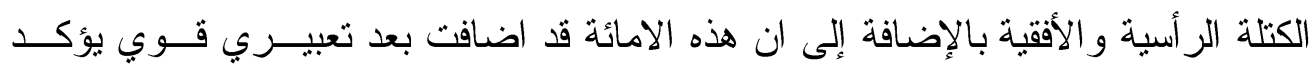

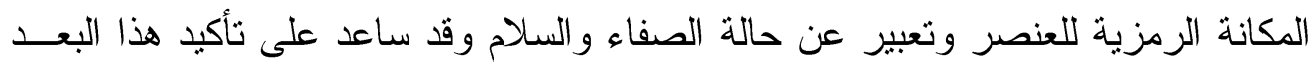

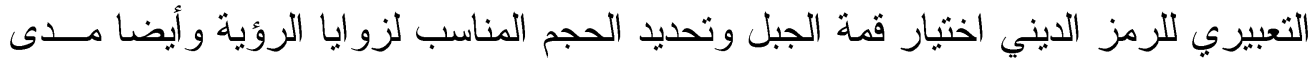

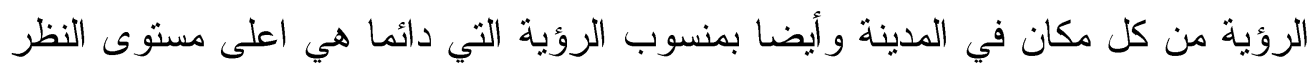

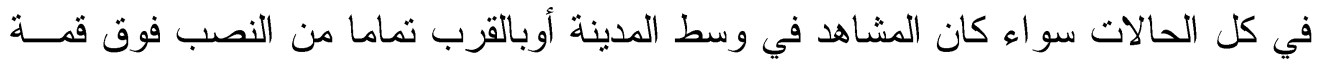

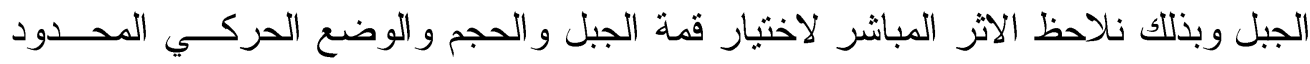

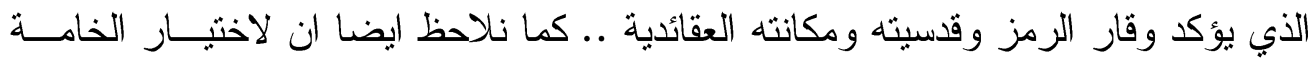

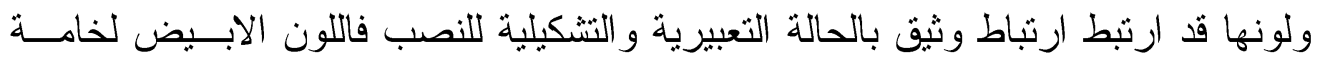

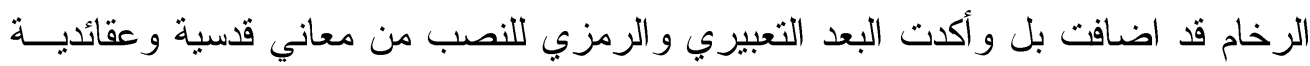

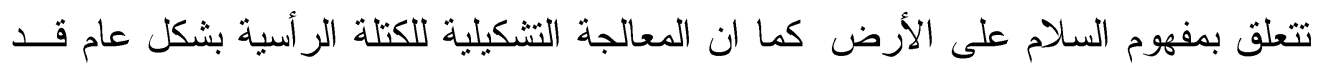

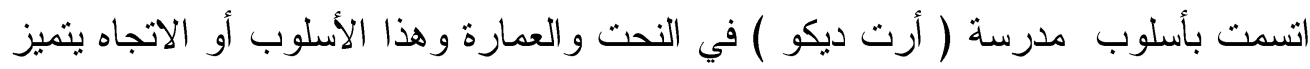
بحلوله الصريحة القوية و النقلات الحادة في صياغة النشكيل النحتي لارنباطه دائما بالعمارة

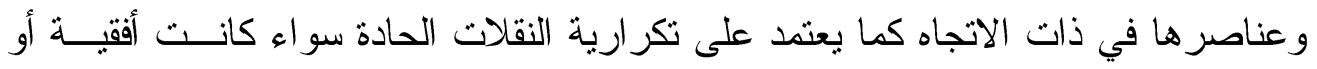

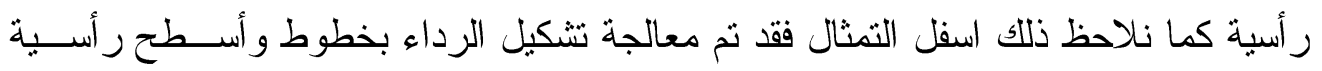

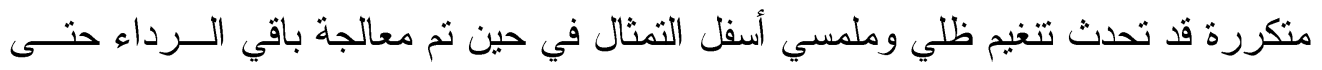

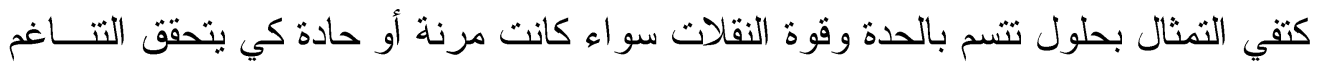
البصري ونوزيع الظل و الضوء على تللك المساحة الهائلة من زو اياها المختلفة ولكي تتناغم الحلول التشكيلية على أسطح الكتلة الر أسية بتمهيد بصري متصاعد وبلاشك أن اتباع هــــا

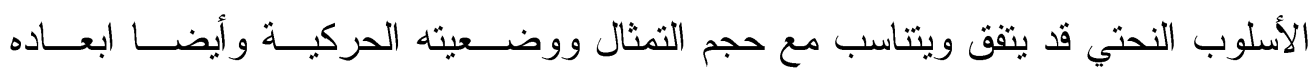

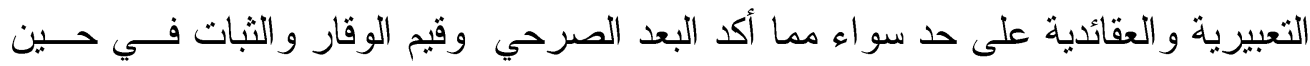

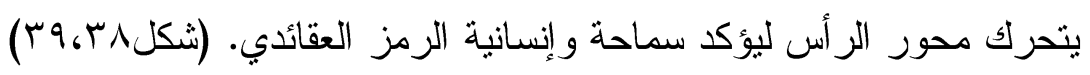

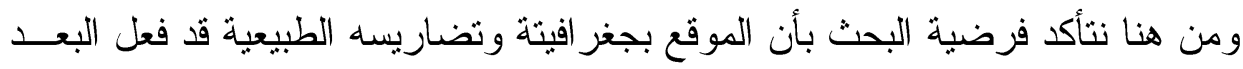

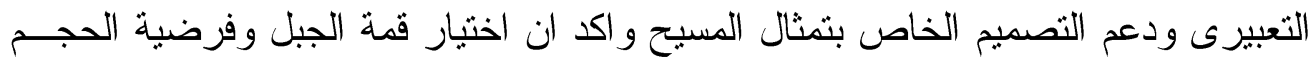
و أسلوب النشكيل وخامته ذات اهمية خاصة حيث يستغل المصمم المعطيات الطبيعية للموقع ونية 
بعناصره وجغر افيته وتضـاريسه كى تصبح هـى الأســاس أو المثبــر المــتمم للتصــميم و المتتاغم مع تصميم النصب التذكاري تشكيليا وتعبيزيا ورمزيا .

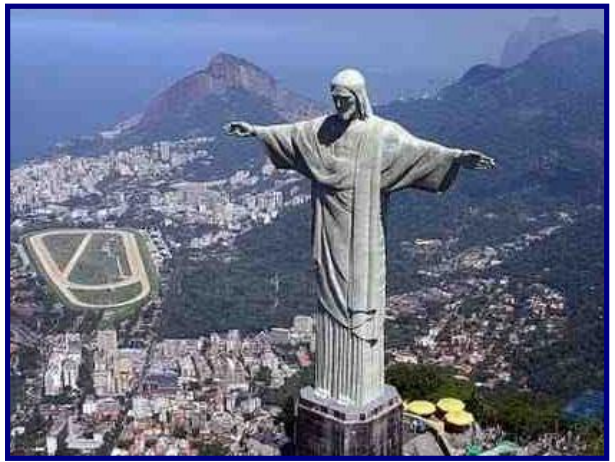

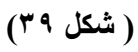

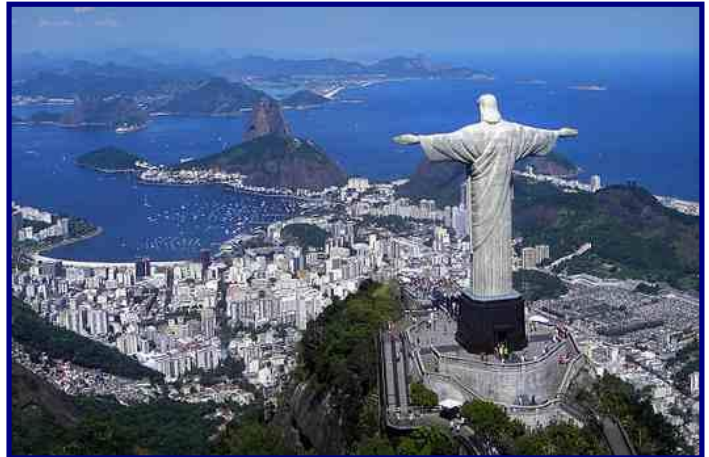

(شكلم^) زاوية روية خلفية من أعلى توضح علاقة موقع التمثال بالمدينة

مقام الشهيد بالجزائر أو رياض الفتح هو نصب تذكاري للحرب الجزائرية يطل على مدينة الجز ائر العاصمة من أعلى قمة جبلية بني عام ب 19 1 احياء الــكرى العشـرون لاســتقلال

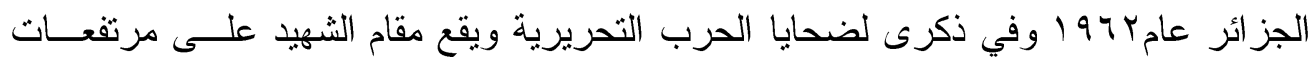
مدينة الجز ائر العاصمة في بلدية المدينة شرق حي ديار المحصول و إلى شمال مركز التسوق رياض الفتح ، و هو بطل أيضا على حديقة التجارب في الثمال الثرقي. (شكل • ع، اعـ ، rع ،

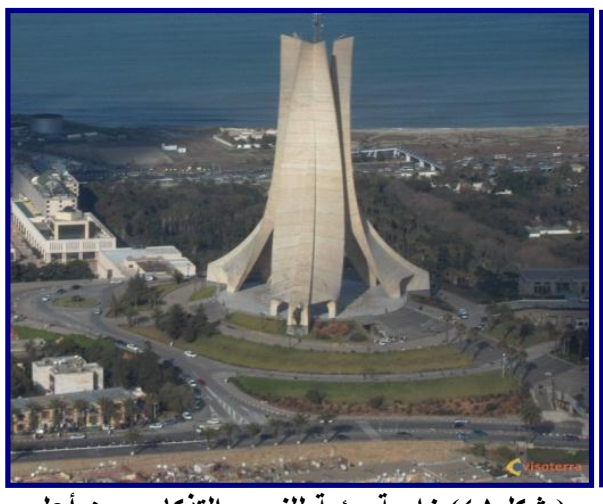

( شكل ا \& ) زاوية روئة للنصب التذكارى من أعلى

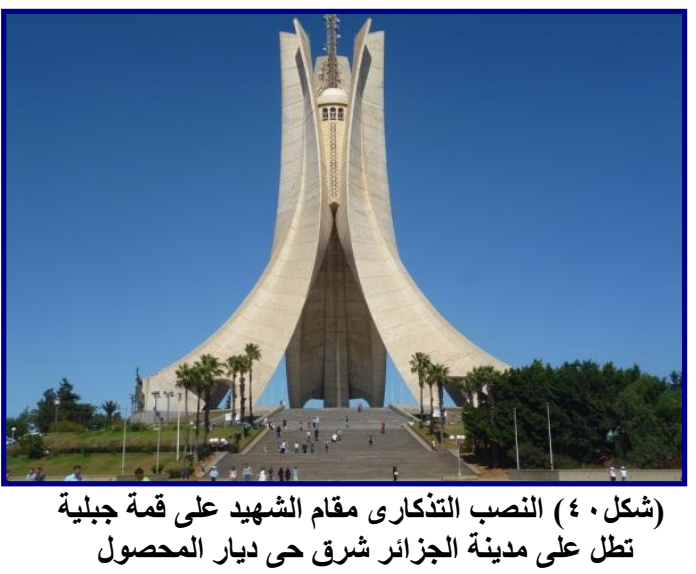




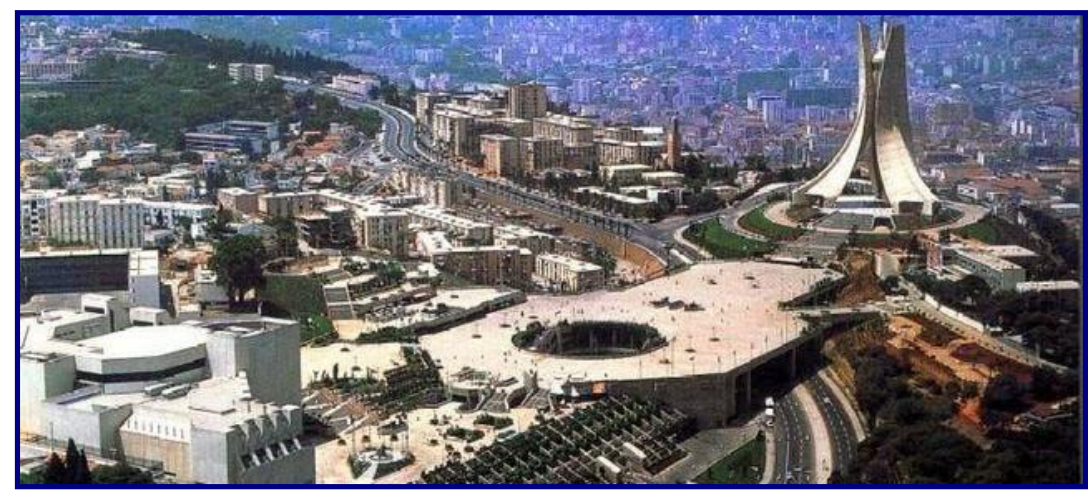

(شكل r ؛ ) زاوية روية للنصب توضح العلاقة الحميمة وزوايا الروئة المتعددة والميطية للنصب من المدينة

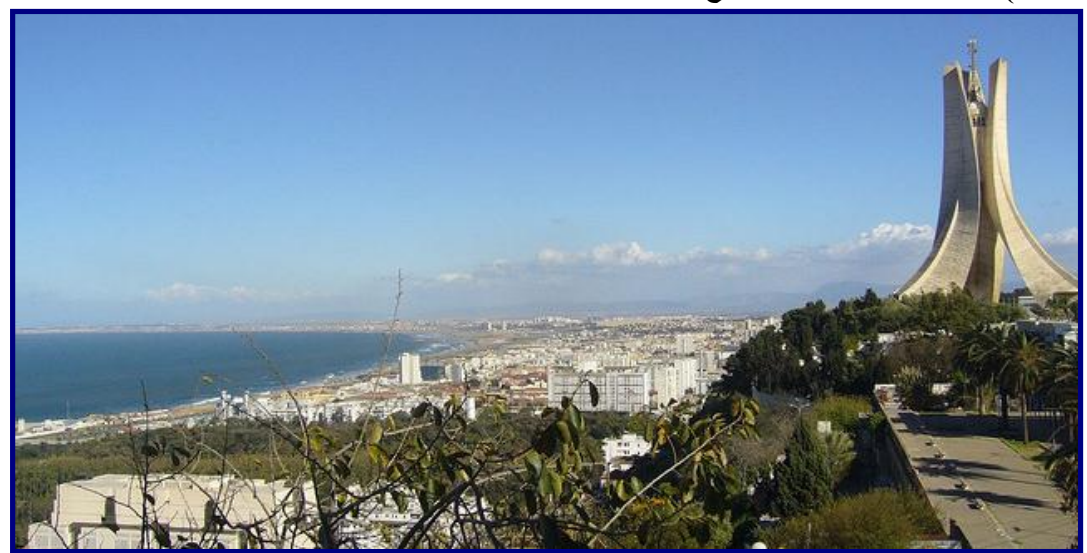

(شكل

وكان الموقع في الماضي مكان عسكري يتكون من عــدة حصـــون عســكرية وهــذا

النصب قد تم تتفيذه بو اسطة شركة كندية ( لافالين ) استتادا إلى نموذج منتج مــن مدرســة الفنون الجميلة في الجزائر العاصمة بقيادة ( بشير يليس ) وهو فنان جزائري من بيلميسان و احد اهم الفنانين المعاصرين بالجز ائر و ارتفاع النصب يقدر بــ ب و م ويتو اجد في ســاحة و اسعة ويقع تحت النصب مباشرة رمز يسمى بالشعلة الابدية و يتضمن سـردابا ومسـدرج ورتحف تحت الأرض بسمى بمتحف المجاهدين وقد كتبت لوحة (شكل عـ ، 0 ؛ )على المقام تكريما وتخليدا للابناء البررة الذين جادو بارو احهم على مر الاجيال و العصور دفاعا عن الوطن المفـدى وتحريــر الأرضــهـ مـنـ الغاصبين و ارساء لاعائم الحرية و العدالة الاجتماعية وضمانا لكر امة الإنسان وحماية لـــه من كل استخلال وتأكيدا لهاويته الحضارية وتدعيما لمقومات شخصــيته الوطنيــة فلـيكن .

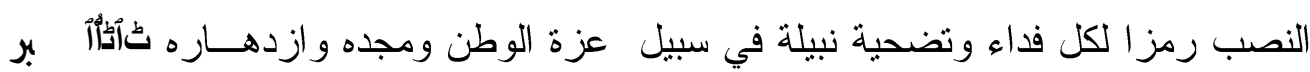
口 $\square$

$$
\text { (") سورة الحج، الآية : • ع }
$$


تششين الصرح العظيم مقام الثهيد على الأرض الجزائرية المعطائة و الذي بــل شــعبها الغالي و النفيس لنيل الحرية وطرد المحتل لتراب الوطن لهذا المفهوم وهذا المعنى قد اقـيم لهيم النصب ليسجل ذكرى رحيل هؤلاء الأبطال وذكرى تحرير الأرض .

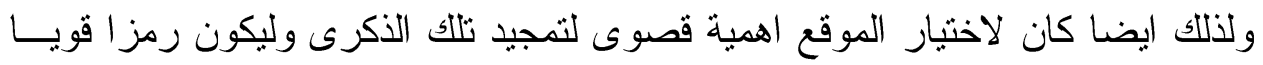

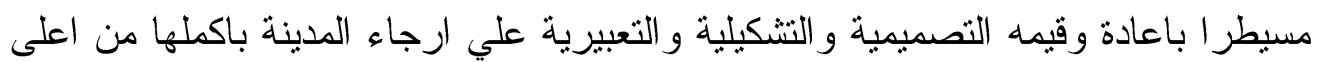

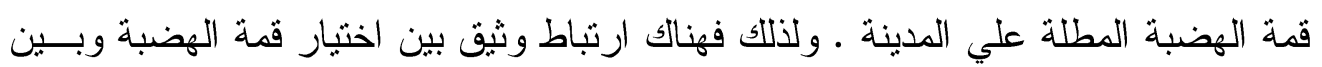

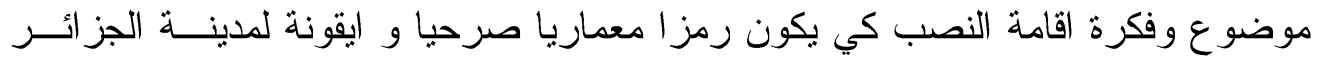

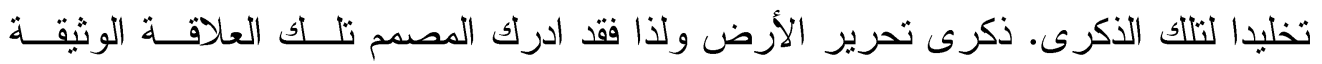
فاستخدم منحدر ات الهضبة خاصة في الساحة المحيطة للنصب كتمهيد مت دـدرج بمســتويات دائرية حول النصب يتخلاها مساحات من السلالم المتدرجة في صعود و وللوصول لســاحة النصب ونقطة بدايته علي الخط الافقي للساحة .

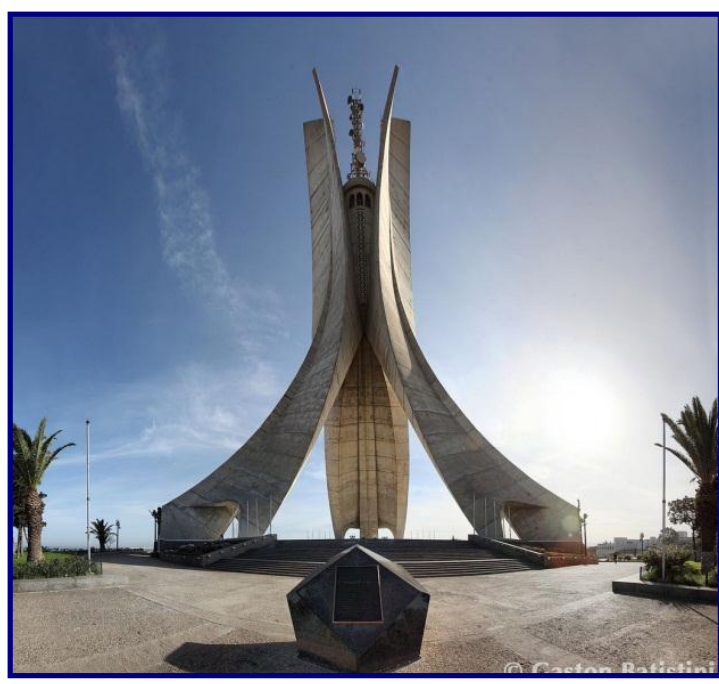

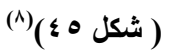

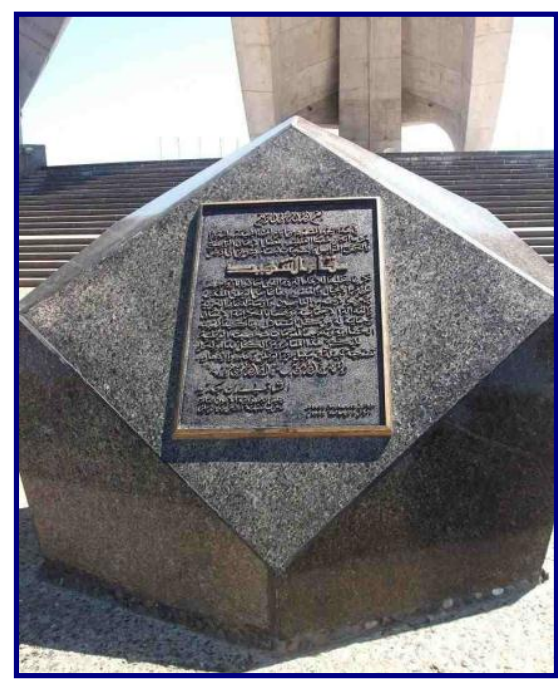

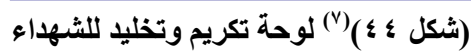

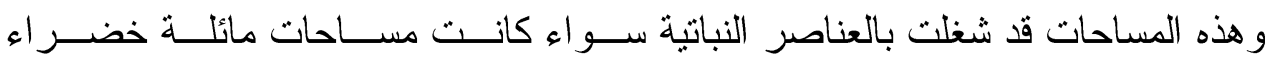

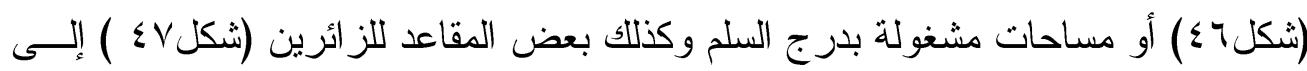

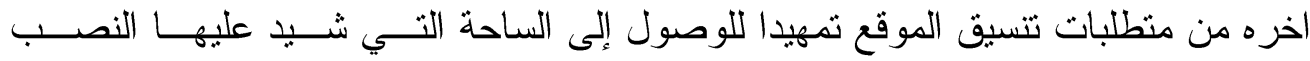
و النصب في مجمله هو تصميم معماري نحتي غاية في بساطة التحليل و الروئية التشــكيلية

$\left.{ }^{7}\right)$ www.er.wikipedia.org

$\left({ }^{8}\right.$ www.startimes.com 
المعمارية القوية والتي تتسم بقيم التشكيل الصرحي وقيم التتغيم الظلي و النقلات الحـادة و

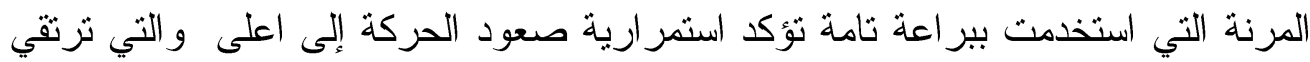
إلى السماء كما توكد مدى استقرار تللك العناصر على السطح الافقي للساحة اسفل النصب .

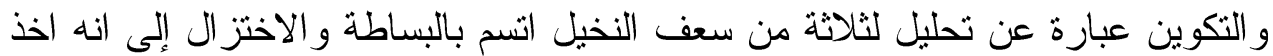

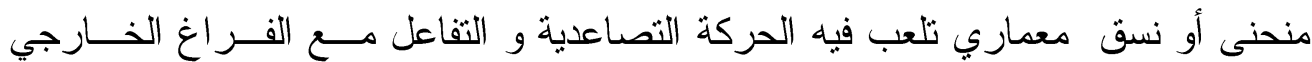

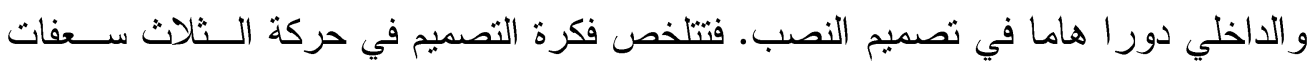

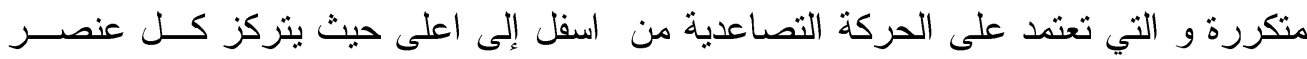

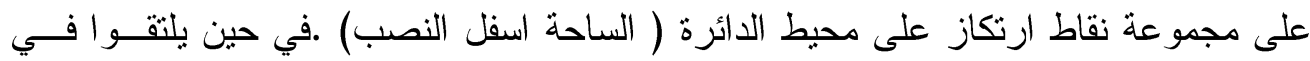
التلث الاخير من ارتفاع النصب بو اسطة كتلة اسطوانية نعانق الثلاث عناصر على أسـطحها

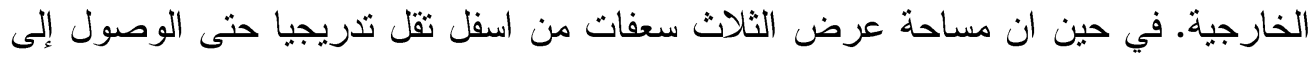
اعلى النصب مما ادى إلى ثأكيد قيم الصرحية و الحركة التصاعدية إلى اعلى (شكل ^^؟) كما

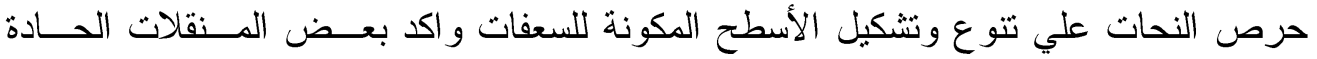

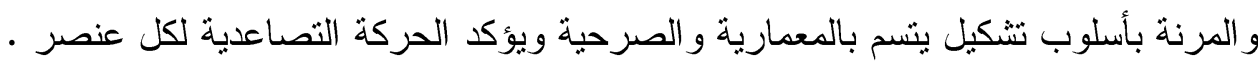

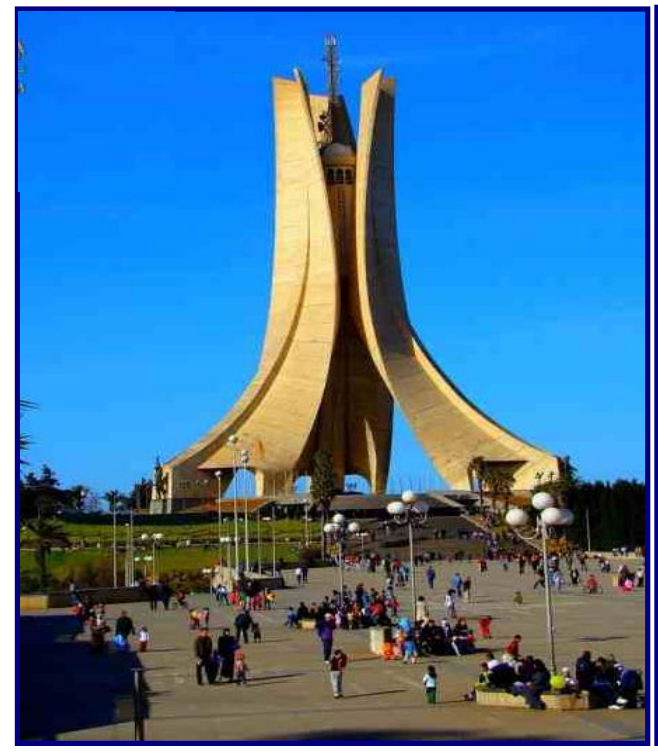

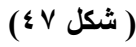

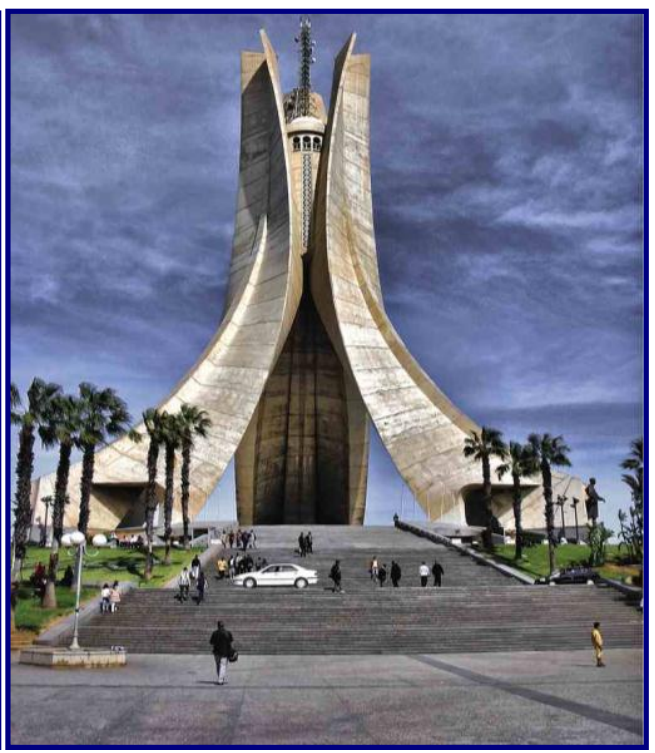

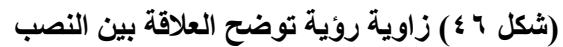

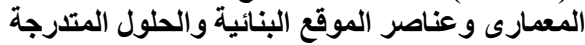

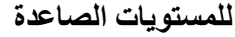

في حين يمكن التعامل عن قرب مع ثلاثة من التماثيل الشخصية التي ترمز إلـى الجنــود

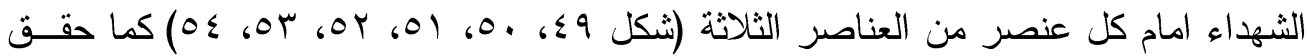


المصمم قيم تشكيلية تتعلق بدور وفاعلية الفر اغ الداخلي المحصور بين الثثلاث سعفات و أرتباط

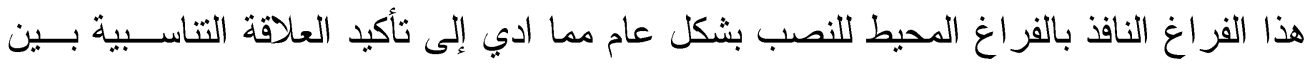

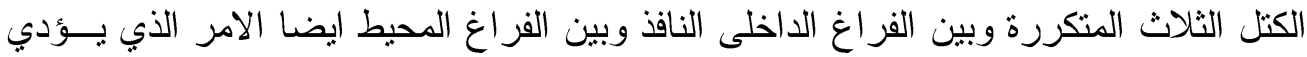
إلى التعامل البصري مع النصب ليس من عن بعد فقط و انما يمكن التواجد داخل الحيز الدائري

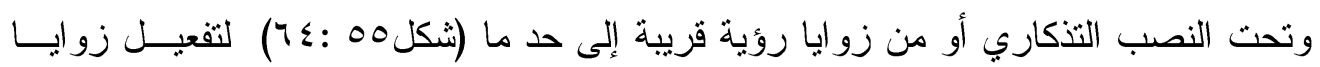
رؤية داخلية مرتبطة بالفر اغ المفتوح ورؤية بانور اما المدينة ورؤية العلاقة التشكيلية للـثنلاث سعفات من منظور وزو ايا رؤية اخرى متعددة تؤكد حالة الانطلاق و الصــعود و الاســتمر ارية لاعلى وتؤكد قيم الصرحية وقيم التشكيل المعماري المتسم بالبساطة في التحليل و الاختز ال.

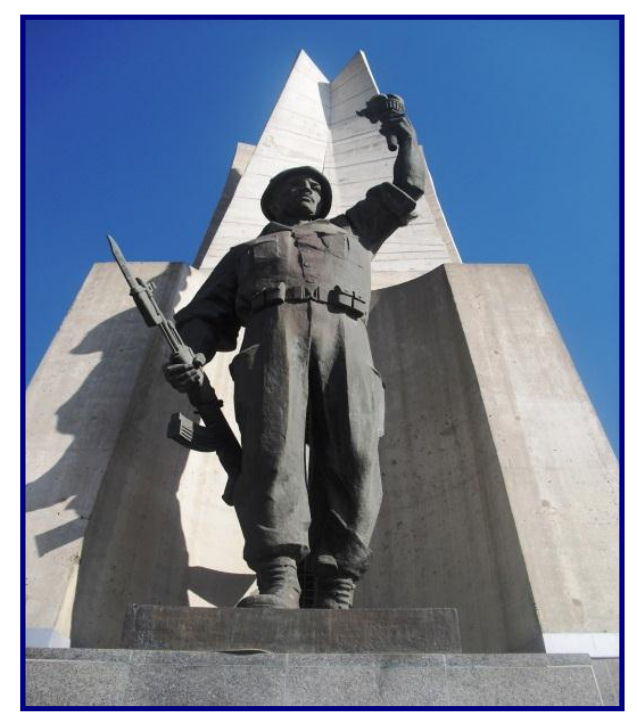

( شكل 9 §) إحدى التماثيل التى ترمز إلى الجنود الثهاء

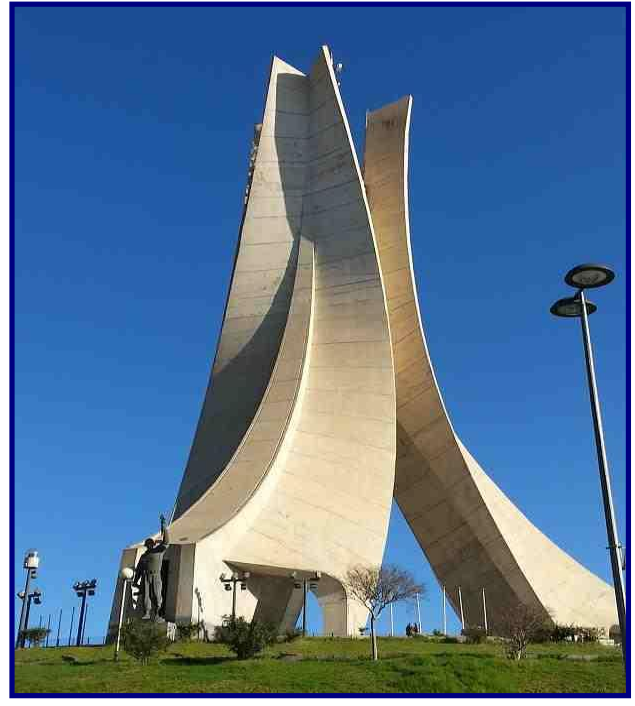

( شكل 1 ؛ ) زاوية روئية توضح الحلول المعمارية

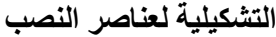

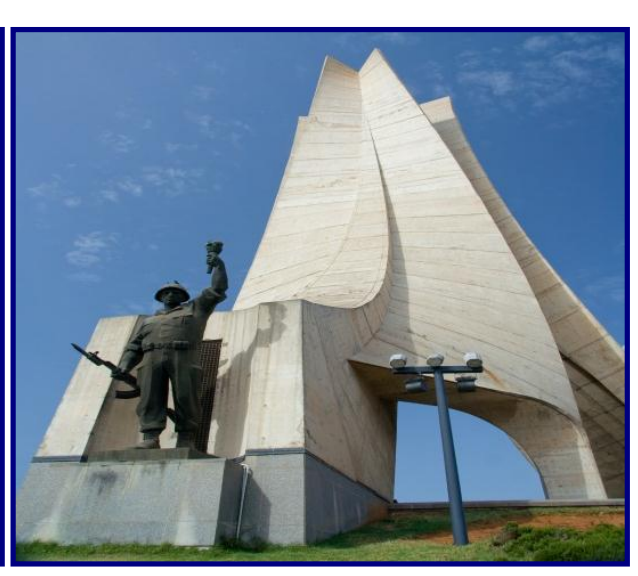

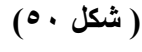

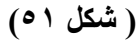

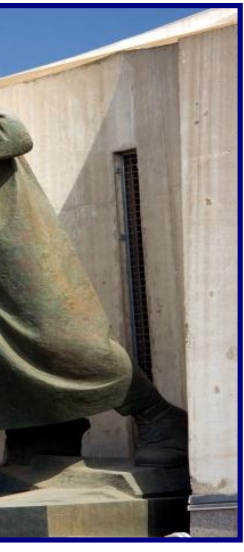


والأثكال التالية لمجموعة التماثيل التى ترمز إلى شهاء الوطن والمرتبطة بالعناصر المعمارية للنصب

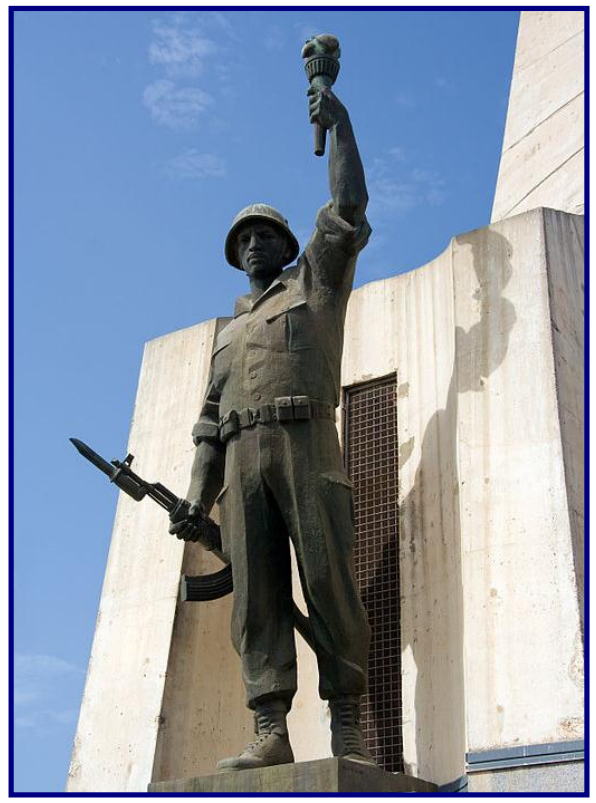

( شكل rOr)

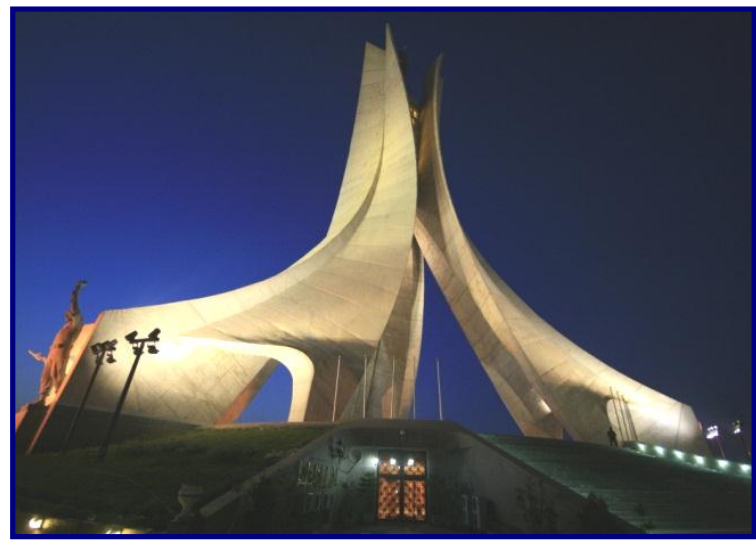

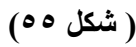

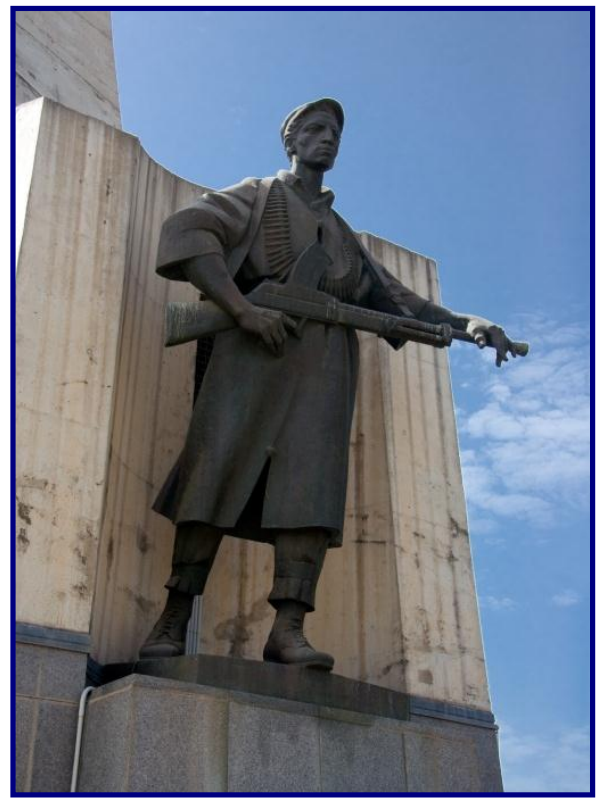

( شكل r o )

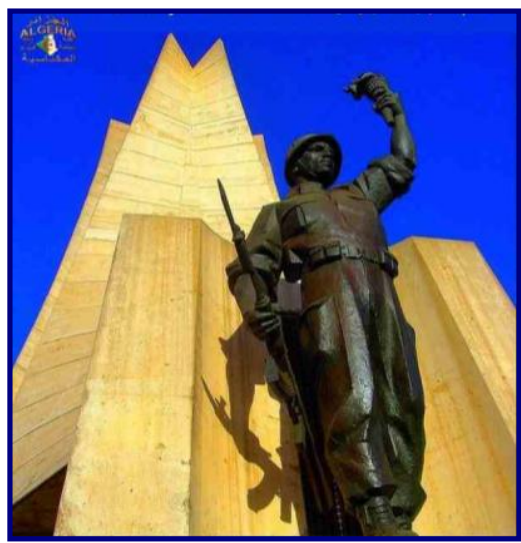

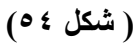

ومجموعة الأشكال التالية لقطات توضح زو ايا رؤية متعددة للنصب ثوضــح مــدى التناول التشكيلى و الحلول المعمارية لعنصر سعف النخيل وعلاقة الثنالثــة عناصــر التـى كتمدت على الحركة التصاعدية ، ثم الإلتقاء فى الثلث الأخير مما أكد قيم الفــر اغ البيئـى النافذ وحقق قيم الصرحية للنصب التذكارى • 

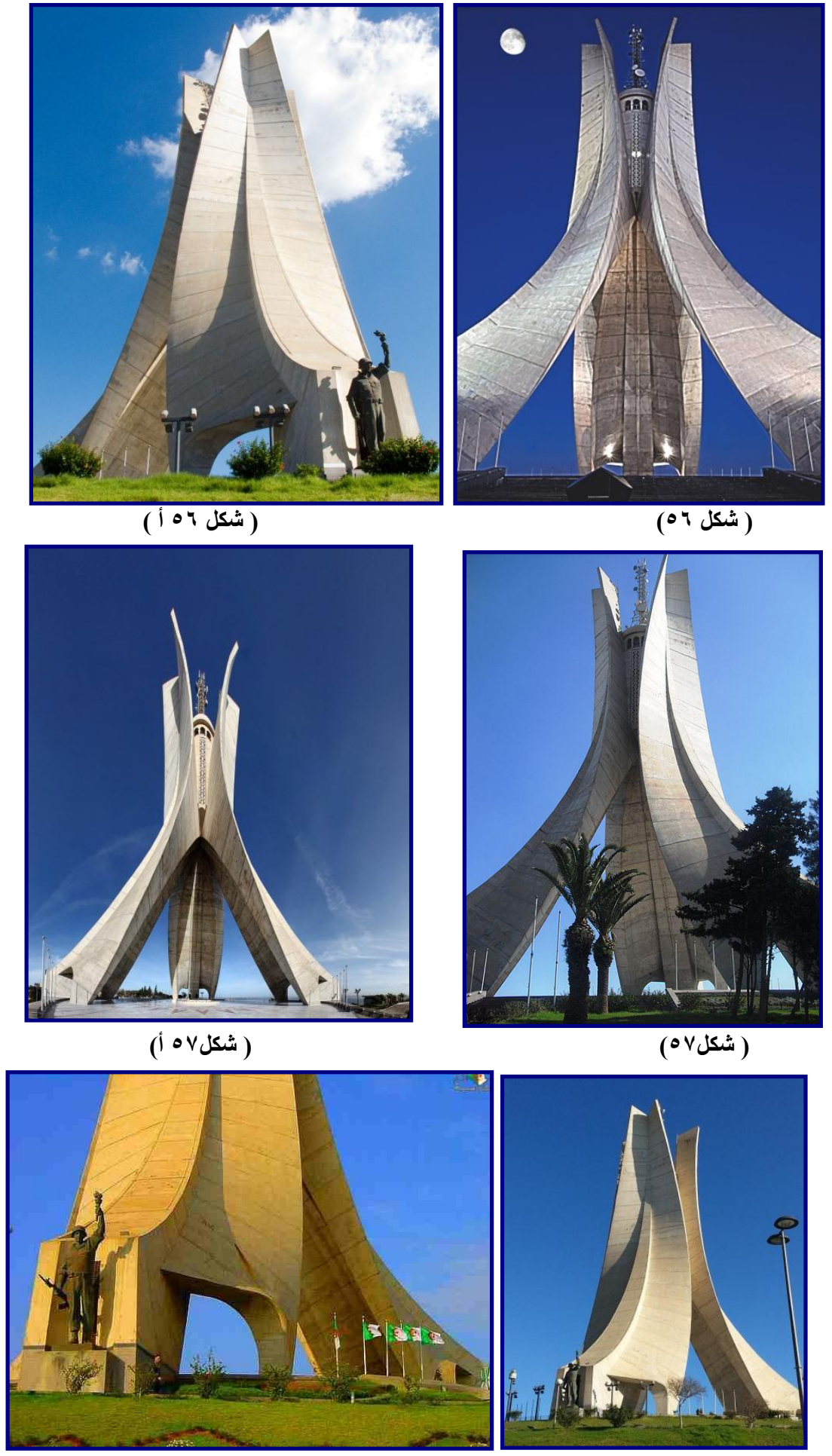

( شكل990)

( شكل^ه ( ) 


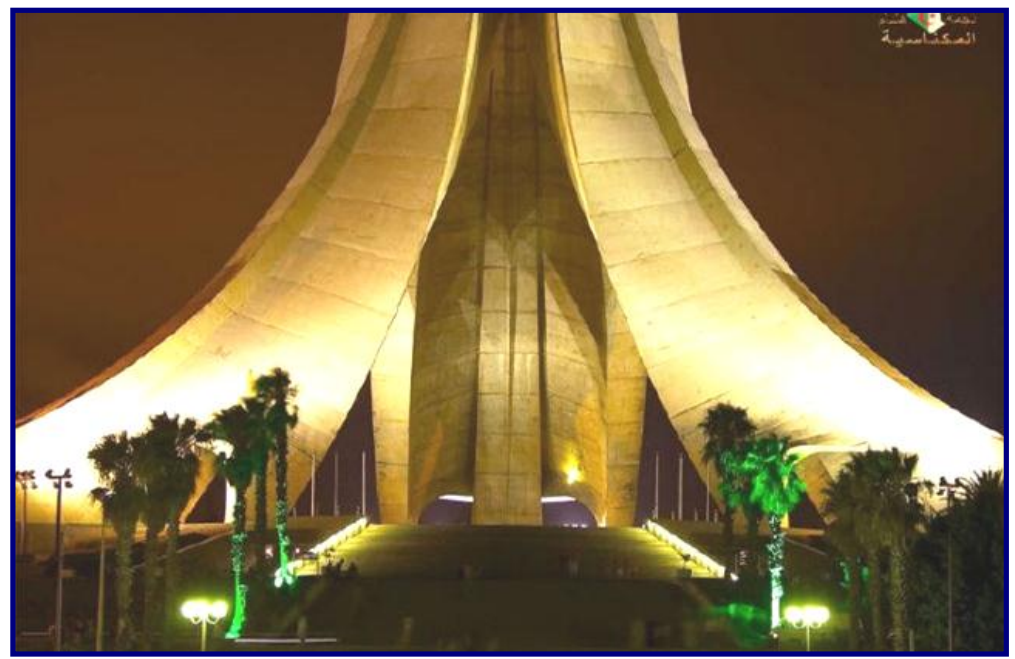

( شكل . (7)
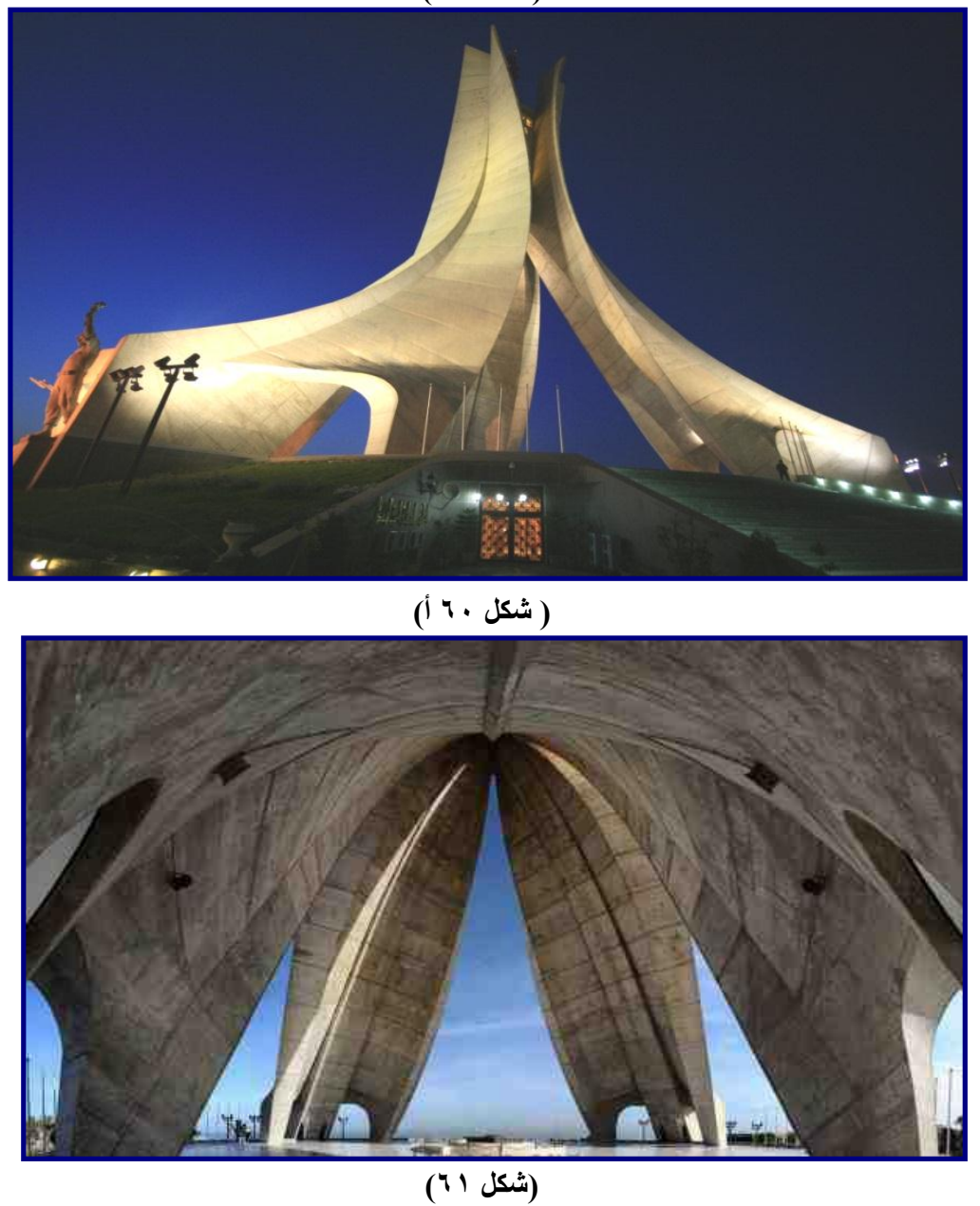


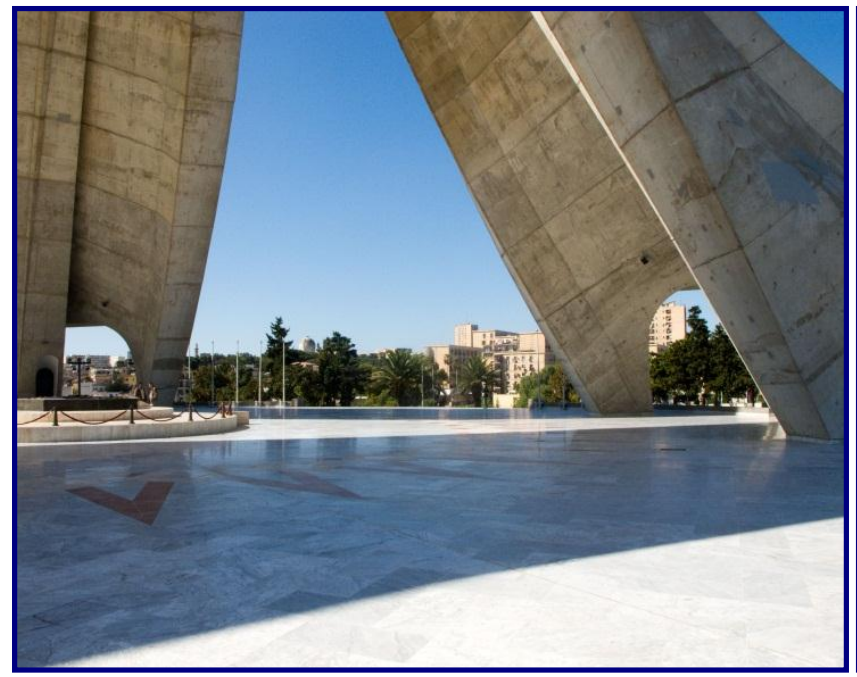

(شكل با T")

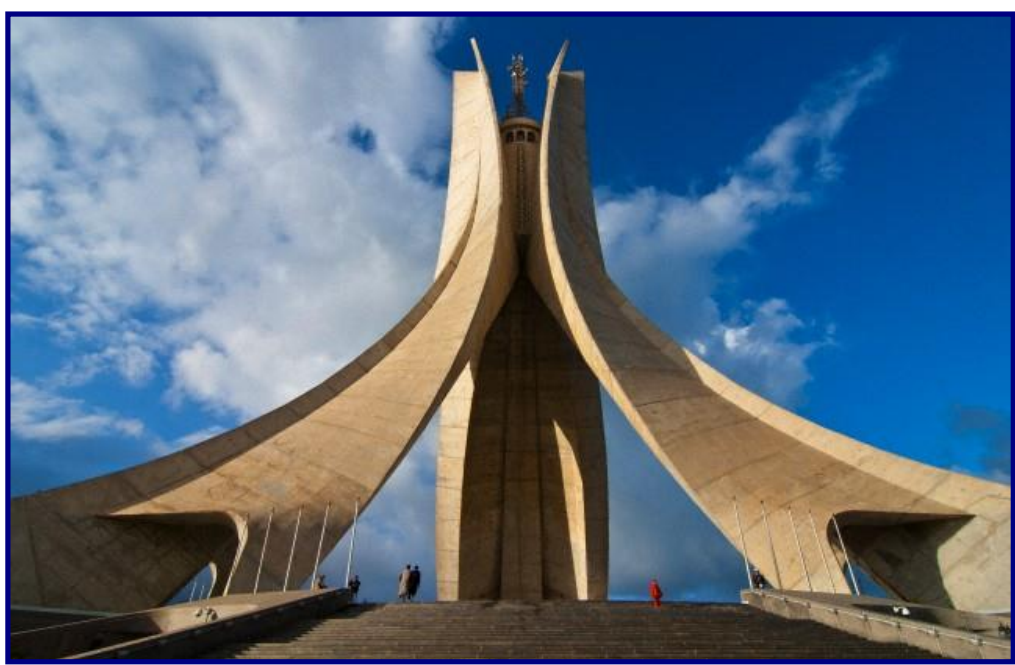

(شكل \& 4 (")

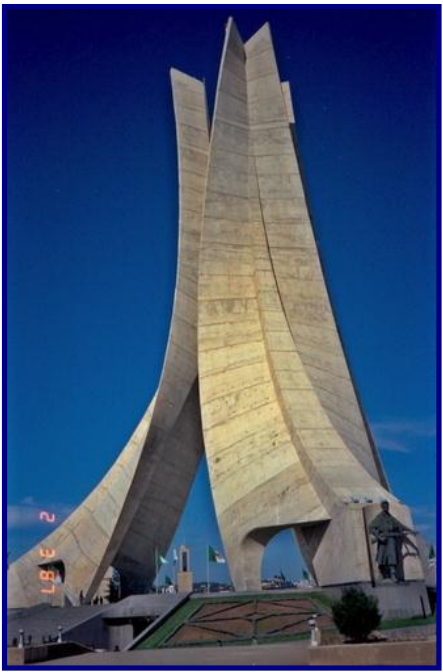

(شكل r T ( T ) 
صعود إلى اعلى قمتها حيث تتتهي ثللك الرؤية المعمارية الصرحية في تكامسلـل مــع طبيعة الجبل من جميع زوايا الرؤية (شكل إئبية

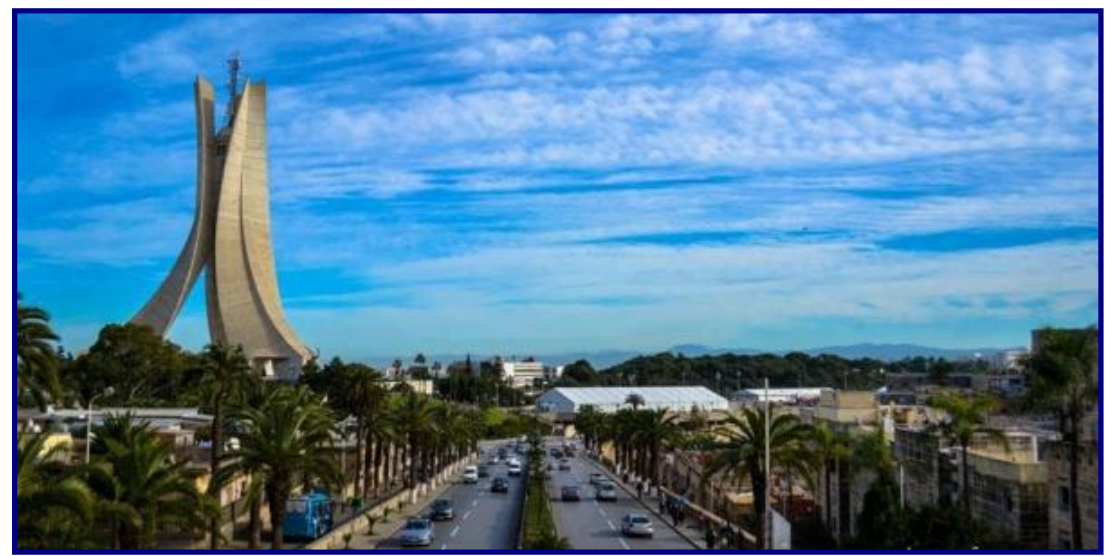

(

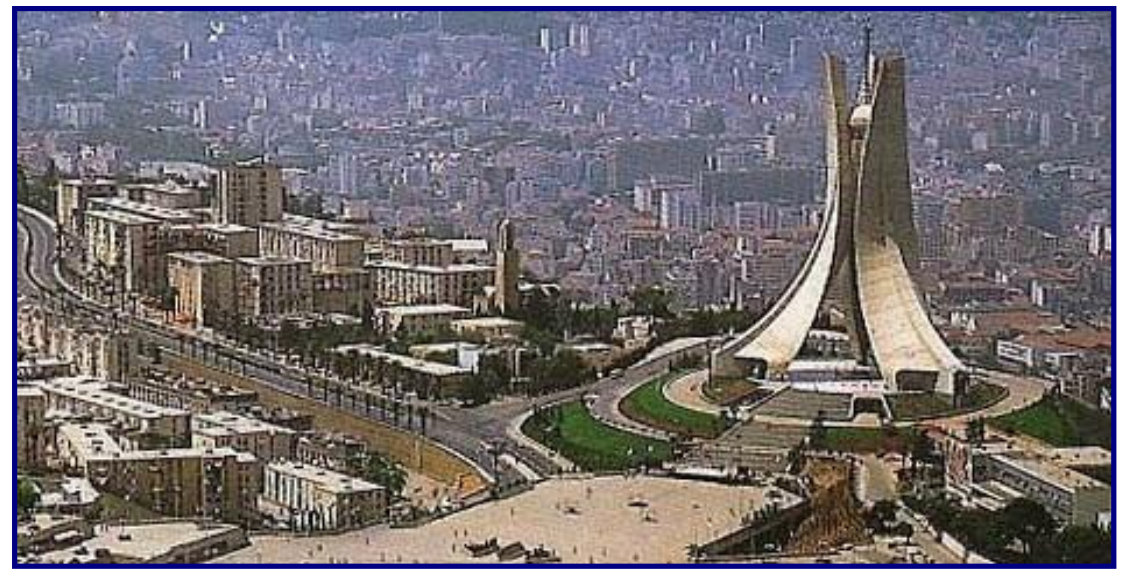

( شكل 74 (

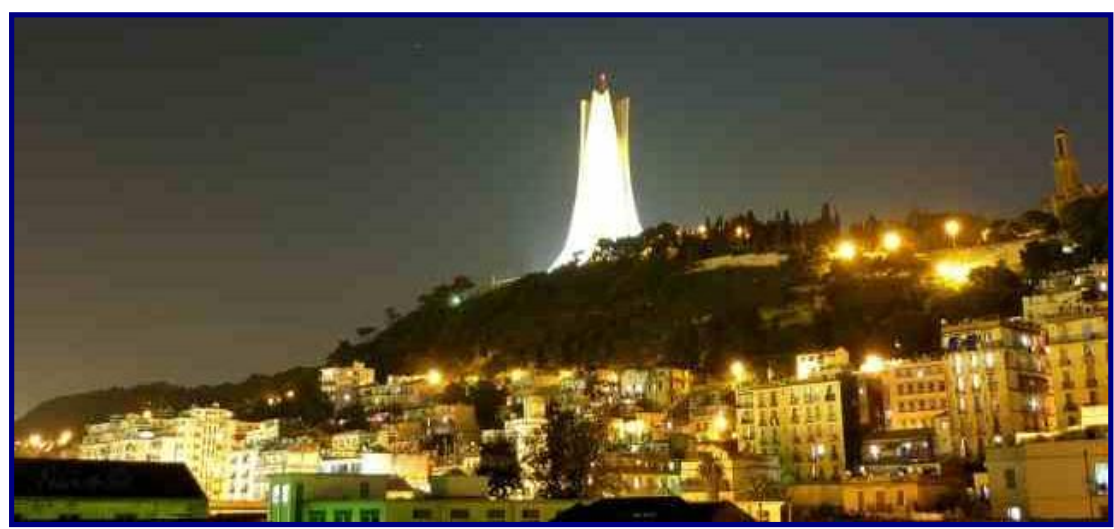

( شكل VI ) مجموعة من زوايا الروئة التى توضح العلاقة البصرية ومدى الروئة المتاح من أماكن متتوعة بالمدينة 


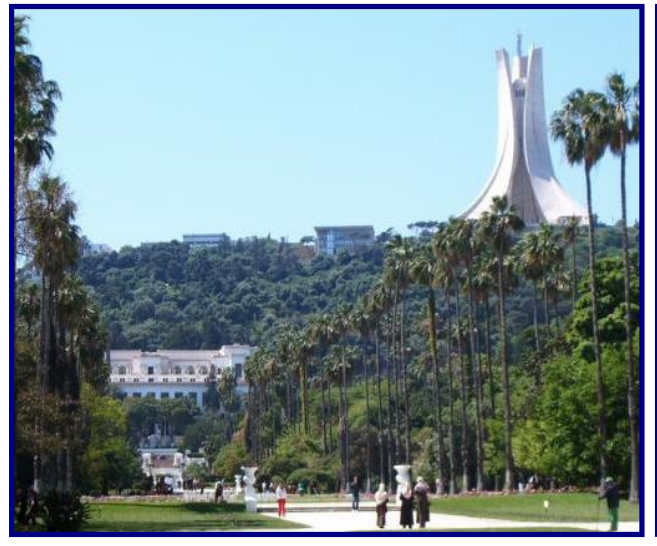

( شكل 9 (9)

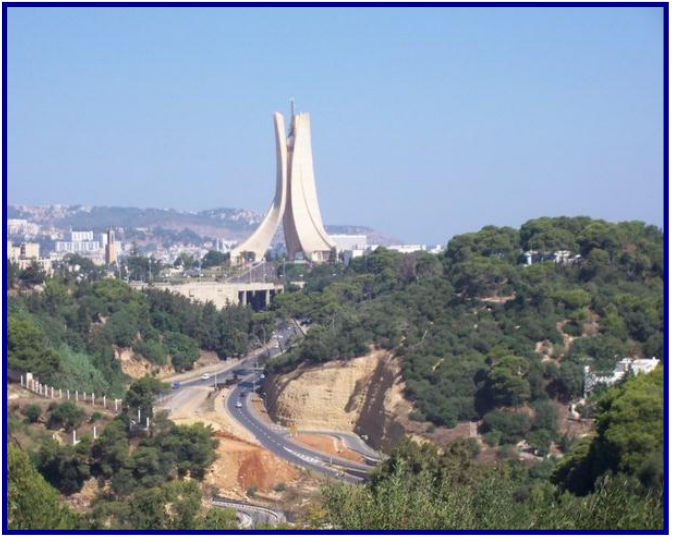

(شكل1 (4)

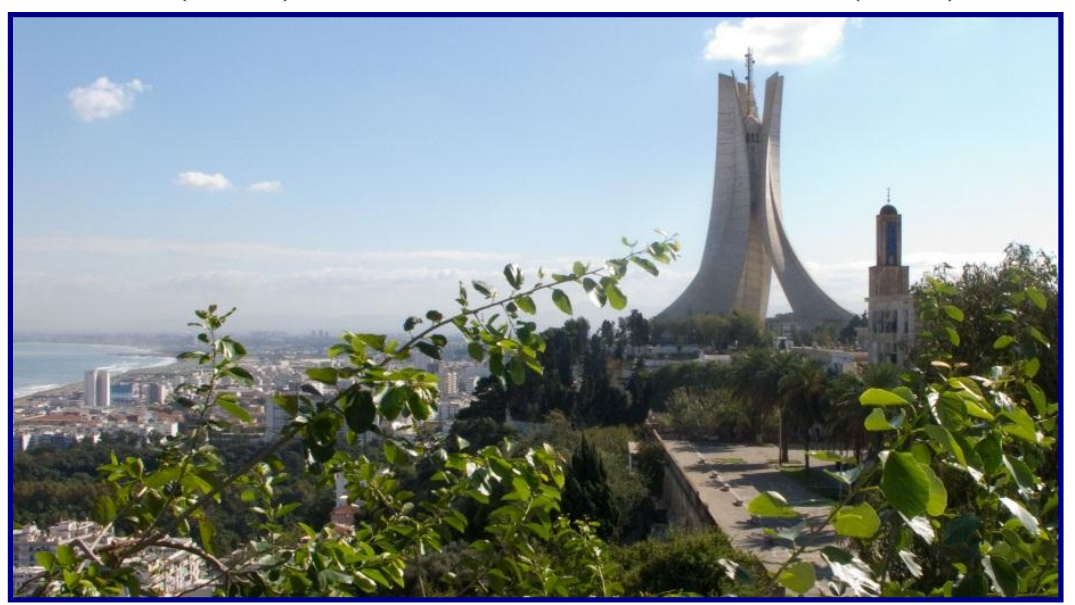

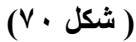

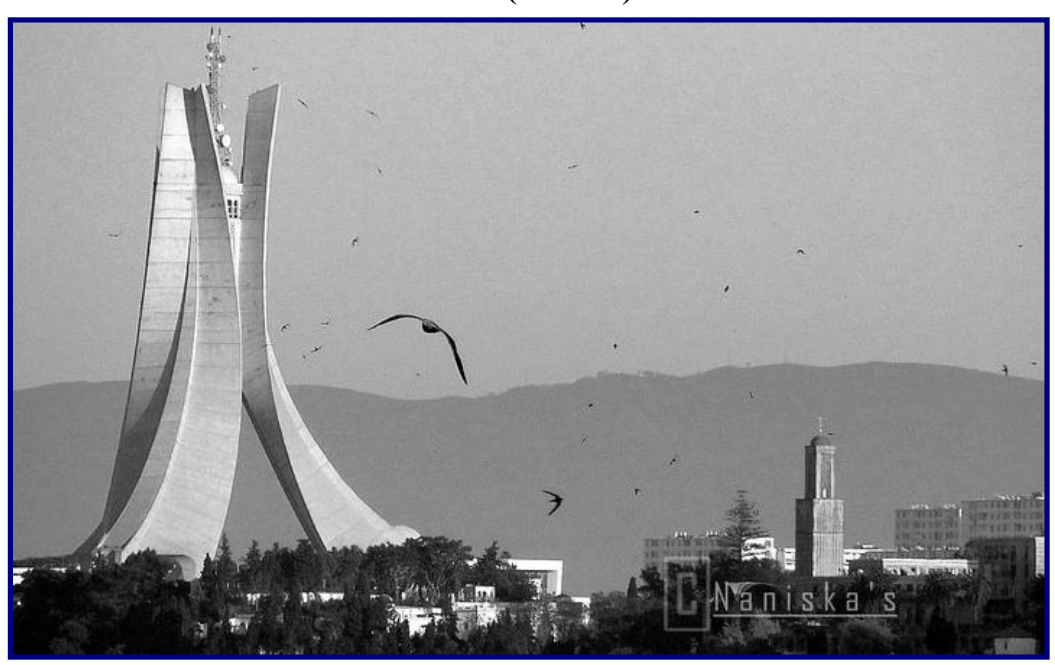

( ش ( 


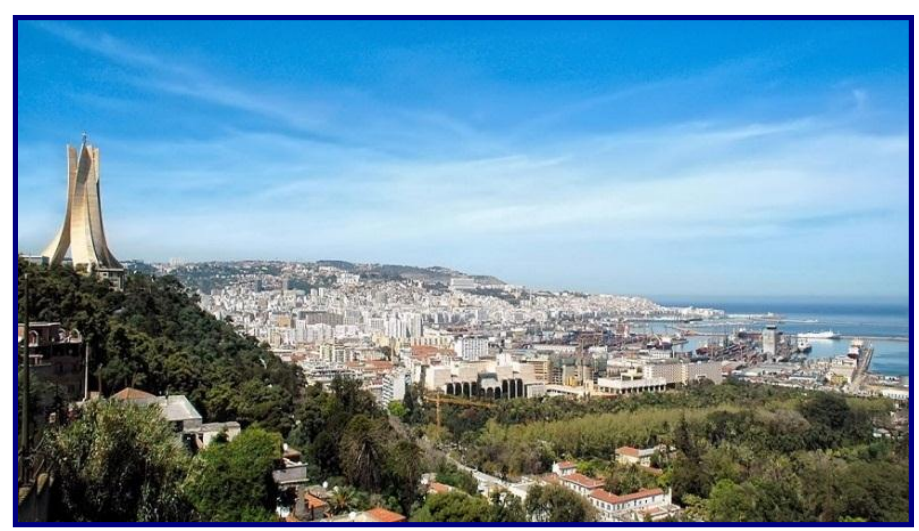

(

ثانيا ... عمل على تفعيل التدرج البصري بمستويات دائرية متصاعدة حول النصب نمهيدا لبداية انطلاق العناصر المعمارية للنصب حيث فعل العناصر النباتية بمختلف كثافتها سو اء كان مساحات خضر اء أو كثافات أثجار متتوعة و التــي تخترقهـــا مســاحات متدرجة من السلالم للوصول إلى ساحة النصب . ثالثا... تفعيل القيم التشكيلية المنعلقة بالرؤية الصرحية لعناصر النصــبـ و ايجــاد العلاقــة الحركية للثلاث عناصر ( السعفات ) برؤية تشكيلية وعلاقة حجمية تتفاعل وتتسق مع الفراغ المحصور بينهم و النافذ إلى خارج النصب بالإضافة إلى قيم الفر اغ المحــيط الذي يؤكد وجود وفاعلية التكوين المعماري بحلوله و حركته المتصـــاعدة والمتســمة بقيم الصرحية سواء في عنصر الحركة أو أسلوب التحليل و النشكيل . رابعا .. تم تفعيل القيم التعبيرية و الابعاد الإنسانية للرمز الخــاص بشـــيد الــوطن وتجريده بتو اجد الثلاث تماثيل البرونزية في محيط الدائزة امام كل عنصر معماري وقد تم معالجة التشكيل في هذه التماثيل بأسلوب و اقعي يتسم بحلول صريحة للجسم البشــري فـي ردائه العسكري كمل فعل الفنان من قيمة الرمز عند كل نمثال فمنهم من حمل السلاح بيد بينما برفع شعلة النصر باليد الاخرى، ومنهم من يرتدي مالابس شعبية ويحمل السلاح رمزا للمقاومسـة الثعبية التي كان لها دور اساسي في المقاومة

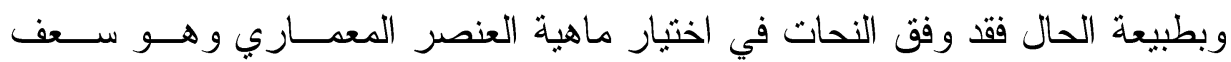

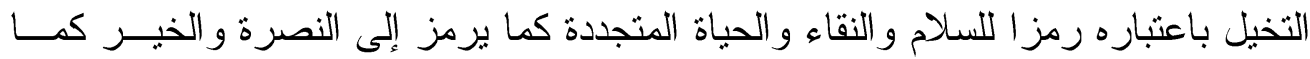
كان له ابعاد رمزية في كثير من العقائد والموروثات الثعبية بشكل عام ، فاختيار الرمسز 
بما يتتاسب مع موضوع النصب من اهم المعايير التي يجـب ان توضــع فـــي الاعتبـار

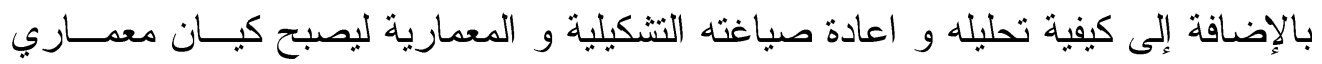

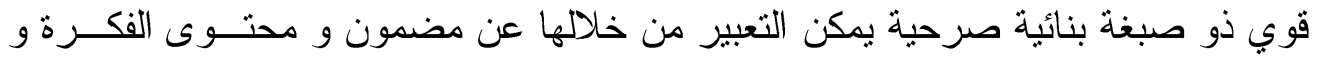
البناء التصميمي لها و إثر ائها تشكيليا و ادائيا

لذا فنحن امام عمل صرحي في المقام الاول قد بنيت فكرته التصميمية على الطبيعـة

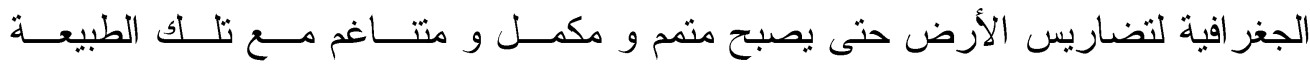
الجغر افية.

و التي تمثل مركز ا بصريا هاما يطل على المدينة باكملها و يستطيع المشــاهد ان يتعاهـلـل

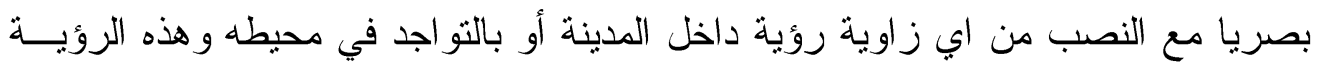

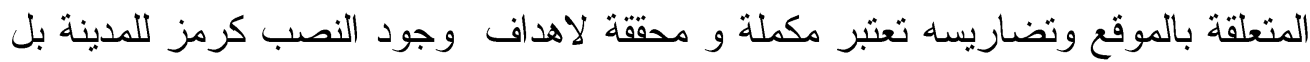

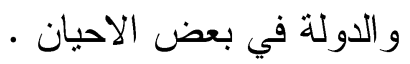
فالنصب التذكاري هو ابداع نحتي أو معماري نحتي مشاء من اجل التذكير بالحـدث

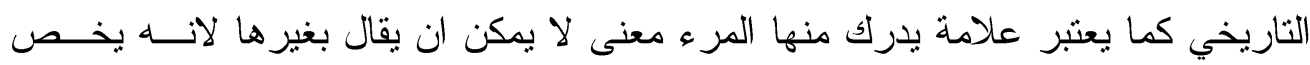

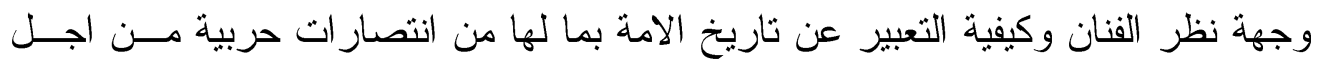

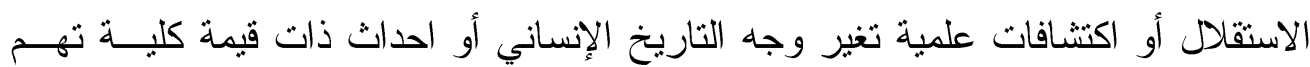

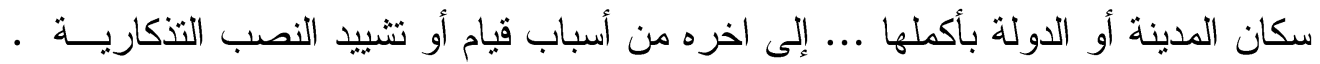
كما انها تعبر عن نبض المدينة ونبض البشر و تشكل ملامح و ثقافات المجتمعات بقــدرثها

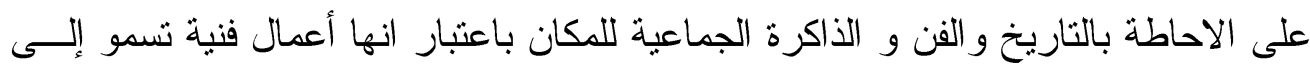
ان تكون علامات ار ادة جماعية و النصب بشكل عام هو نوع خاص من الأعمال الفنية التي تعبر عن الإنسان و الزمان و المكان و تربط بين ماضي المدينة و مستقبلها ، وهذه الخصوصية تترك نتائج و رسـائل

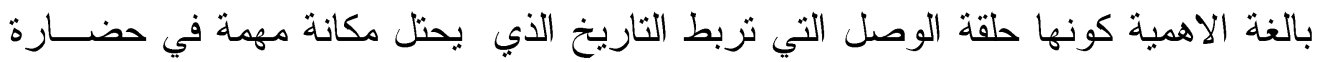

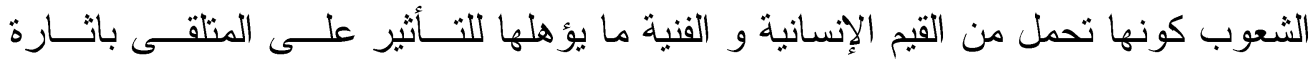
مشاعره و افكاره فهي رسالة تخاطب الحاضرين كما تخاطب اجيالا لم يأتي بها الزمان بعد. 
وتتلخص النتائج ذات العمق التخصصى فى الأعمال المقامة فى الحيز ات الخارجيــة

$$
\text { فيما يلى : }
$$

- لقد ثبت من العرض التحليلى مدى فاعلية خط الأرض فى تعميق وتأكيد البعد التصميمى

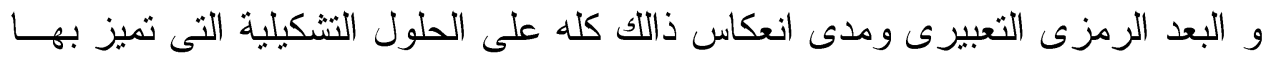
النصب

- لقد ثبت بالتحليل ايضا مدى اهمية التدرج ومدى عمق فاعليته فى تحقيق رؤى مثتوعـة

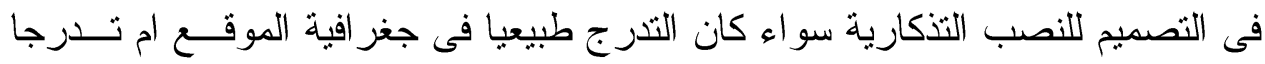
فرضه الفنان كضرورة لتحقيق التكثيف الرمزى الذى يهدف اليه ــوفى كل من الحالتين

يتحقق التو افق و الوحدة العضوية التى تليق بقومية النصب و رمزينها

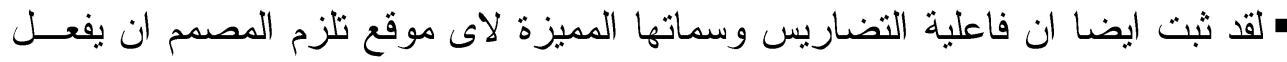

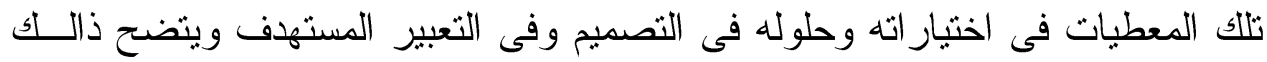
بجلاء من خلال استعر اض أعمال منفذة على المستوى العالمى بما يدعم الخصوصـــية وهية

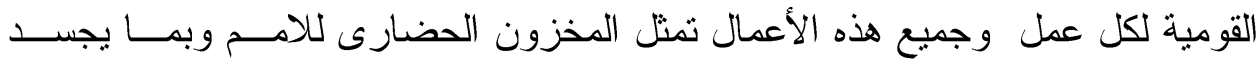

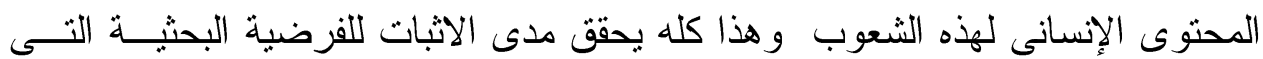
اسس لها هذا البحث من منظور هذه النتائج الهامة لهده 